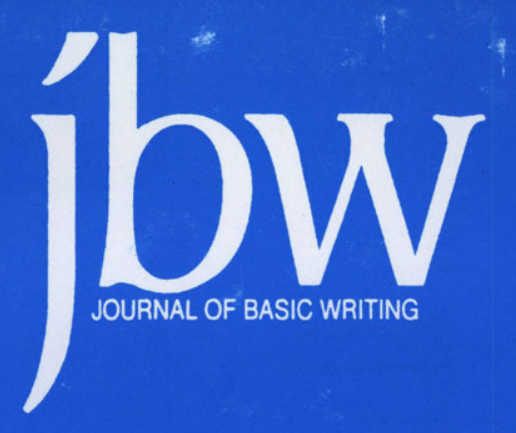

\title{
FALL 2000
}

VOLUME 19 NUMBER 2

Engaging Students in Writing-To-Learn: Promoting Language and Literacy Across the Curriculum Vivian Zamel

Basic Writing, CUNY, and "Mainstreaming": (De)Racialization Reconsidered Steve Lamos

Looking Back, Looking Forward: California Grapples with "Remediation" Mary Kay Crouch and Gerri McNenny

"It's the Way that They Talk to You": Increasing Agency in Basic Writers Through a Social Context of Care Joan L. Piorkowski and Erika Scheurer

A Method for Describing Basic Writers and Their Writing: Lessons from a Pilot Study Deborah Rossen-Knill and Kim Lynch

Checking the Grammar Checker: Integrating Grammar Instruction with Writing Patricia J. McAlexander

Breaking the Block: Basic Writers in the Electronic Classroom Judith Mara Kish 



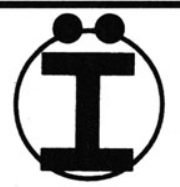

The paper used in this publication meets the minimum requirements of the American National Standard for Information Science -

Permanence of Paper for Printed Library Materials, ANSI Z39.48-1984.

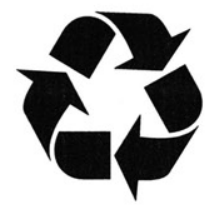

The text stock is also recycled.

\section{This publication is available in microform from UMI.}

Please send me information about the titles I've listed below:

Name

Title

Company/Institution

Address

City/State/Zip

Phone (_

\section{U.M.I}

A Bel I \& Howell Company 300 North Zeeb Road, Ann Arbor, M 48106 USA 800-521-0600 toll-free 313-761-4700 collect from Alaska and Michigan 800-343-5299 toll-free from Canada 



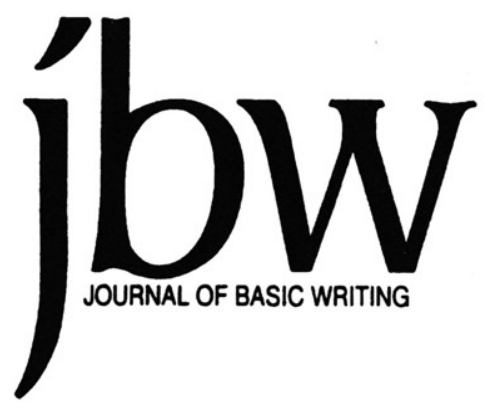

VOLUME 19 NUMBER 2

FALL 2000

The Journal of Basic Writing publishes articles of theory, research, and teaching practices related to basic writing. Articles are refereed by members of the Editorial Board (see overleaf) and the Editors.

Trudy Smoke and George Otte Editors

\title{
Rhona Cohen and Linda Camarasana Editorial Assistants
}

\section{Mary E. Carney, Subscriptions}

The Journal of Basic Writing is published twice a year, in the spring and fall. We welcome unsolicited manuscripts and ask authors to consult the detailed "Call for Articles" in this issue. Subscriptions for individuals are $\$ 15.00$ for one year and $\$ 28.00$ for two years; subscriptions for institutions are $\$ 20.00$ for one year and $\$ 38.00$ for two years. Foreign postage is $\$ 5.00$ extra per year. ADDRESS:

\author{
Journal of Basic Writing \\ City University of New York \\ 555 West 57 Street, Room 1601 \\ New York, NY 10019
}




\section{JOURNAL OF BASIC WRITING \\ EDITORIAL BOARD}

Peter Dow Adams

Essex Community College, Baltimore

Akua Duku Anokye

University of Toledo

Chris M. Anson

North Carolina State University

David Bartholomae

University of Pittsburgh

Sarah Benesch

College of Staten Island, CUNY

Bill Bernhardt

College of Staten Island, CUNY

Patricia Bizzell

College of the Holy Cross

Lynn Z. Bloom

University of Connecticut, Storrs

Nancy Carriuolo

University of New Haven

Richard Courage

Westchester Community College,

SUNY

Donald Daiker

Miami University

Suellynn Duffey

Ohio University

Sarah Warshauer Freedman

University of California, Berkeley

Karen L. Greenberg

Hunter College, CUNY

Brenda M. Greene

Medgar Evers College, CUNY

Muriel Harris

Purdue University

Irvin Hashimoto

Whitman College

Warren Herendeen

Mercy College

Myra Kogen

Brooklyn College, CUNY
Patricia Ondek Laurence

City College, CUNY

Elaine O. Lees

Carlow Hill College

Andrea A. Lunsford

Ohio State University

Jane Maher

Nassau Community College

Peter Miller

College of Staten Island, CUNY

Susan Miller

University of Utah

Nathaniel Norment, Jr.

Temple University

Jerrold Nudelman

Queensborough Community

College, CUNY

Jane Peterson

Richland College, Dallas County

Community College Distnct

Nell Ann Pickett

Hinds Community College

Charles I. Schuster

University of Wisconsin, Milwaukee

Tony Silva

Purdue University

Lynn Quitman Troyka

Oueensborough Community

College, CUNY, ret.

Karen S. Uehling

Boise State University

Billie J. Wahlstrom

University of Minnesota

Evelyn E. Webb

Mississippi State Board for

Community and Junior Colleges

Harvey S. Wiener

Marymount Manhattan College 


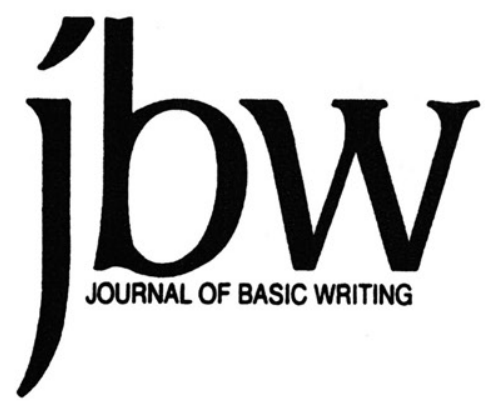

VOLUME 19

Engaging Students in Writing-To-Learn: Promoting

Language and Literacy Across the Curriculum

Vivian Zamel

Basic Writing, CUNY, and "Mainstreaming":

(De)Racialization Reconsidered

Steve Lamos

Looking Back, Looking Forward: California

Grapples with "Remediation"

Mary Kay Crouch and Gerri McNenny

"It's the Way that They Talk to You": Increasing Agency in Basic Writers Through a Social Context of Care Joan L. Piorkowski and Erika Scheurer

A Method for Describing Basic Writers and Their Writing: Lessons from a Pilot Study

Deborah Rossen-Knill and Kim Lynch

Checking the Grammar Checker:

Integrating Grammar Instruction with Writing

Patricia J. McAlexander

Breaking the Block:

Basic Writers in the Electronic Classroom

Judith Mara Kish

News and Announcements 


\section{CALL FOR ARTICLES}

We welcome manuscripts of 10-20 pages on topics related to basic writing, broadly interpreted.

Manuscripts will be refereed anonymously. We require five copies of a manuscript and an abstract of about 100 words. To assure impartial review, give author information and a short biographical note for publication on the cover page only. Papers which are accepted will eventually have to supply camera-ready copy for all ancillary material (tables, charts, etc.). One copy of each manuscript not accepted for publication will be returned to the author, if we receive sufficient stamps (no meter strips) clipped to a self-addressed envelope. Submissions should follow current MLA guidelines.

All manuscripts must focus clearly on basic writing and must add substantively to the existing literature. We seek manuscripts that are original, stimulating, well-grounded in theory, and clearly related to practice. Work that reiterates what is known or work previously published will not be considered.

We invite authors to write about such matters as classroom practices in relation to basic writing theory; cognitive and rhetorical theories and their relation to basic writing, social, psychological, and cultural implications of literacy; discourse theory, grammar, spelling, and error analysis; linguistics; computers and new technologies in basic writing; English as a second language; assessment and evaluation; writing center practices; teaching logs and the development of new methodologies; and cross-disciplinary studies combining basic writing with psychology, anthropology, journalism, and art. We publish observational studies as well as theoretical discussions on relationships between basic writing and reading, or the study of literature, or speech, or listening. The term "basic writer" is used with wide diversity today, sometimes referring to a student from a highly oral tradition with little experience in writing academic discourse, and sometimes referring to a student whose academic writing is fluent but otherwise deficient. To help readers therefore, authors should describe clearly the student population which they are discussing.

We particularly encourage a variety of manuscripts: speculative discussions which venture fresh interpretations; essays which draw heavily on student writing as supportive evidence for new observations; research reports, written in nontechnical language, which offer observations previously unknown or unsubstantiated; and collaborative writings which provocatively debate more than one side of a central controversy. 


\section{EDITORS' COLUMN}

Basic writing continues to hold its place on the academic map as the articles in this issue will attest. Whether we examine BW from the perspective of linguistically diverse students, of race and racism, or of politics, or instead look more closely at individual students' interactions (including computer-mediated ones), we realize that basic writers invigorate academia. We learn from these students that learning is, as Vivian Zamel's student writes, "a metamorphosis with no ending."

Student voice is at the heart of Zamel's essay - a paper based on her keynote presentation at a professional development event for CUNY's university-wide writing-across-the-curriculum initiative. Zamel's explanation of what writing-to-learn pedagogy should be and how we should be doing it is reinforced by the words of her students, students who had been silenced because of language concerns, but who through writing have found and developed their voices.

Silence plays an ironic role in Steve Lamos' essay, which examines the discourse of racism itself. Lamos looks at how the politics of open admissions has created a racialized discourse about BW students, racializing all BW students as "minorities" despite the significant number of whites who have benefited from basic writing programs. And he suggests that this racialized discourse itself has been part of the argument used to deny BW a place in higher education.

The future of remediation also concerns Mary Kay Crouch and Gerri McNenny, teaching in a state with particular pressure to reduce the presence of remedial instruction in higher education. In their article, they describe how collaborations between California State University and the high schools have helped reduce the need for college remediation and explain how these efforts have enabled college and high school teachers to work together with respect and support for each other.

Learning to work together with respect may provide answers for why some students regard teachers and tutors as resources and others do not. In their essay, Joan L. Piorkowski and Erika Scheurer write that "when students perceive a context of care in the basic writing classroom they are more likely to take on 'responsible' attitudes and behaviors - such as valuing and seeking out feedback from others on their writing."

Most of us agree that not all basic writers are alike, but we probably also agree that not enough research has been done to articulate the differences. In their essay, Deborah Rossen-Knill and Kim Lynch 
describe the findings of their study of basic writing students at three institutions: a 2-year rural community college, a 2-year urban community college, and a 4-year urban college. They conducted a survey and met with students for "back talk" interpretation of their responses to the surveys. They also took a close look at the students' writing in these institutions, examining grammatical correctness and the use of rhetorical conventions such as introductions, transitions, and conclusions.

In arguing for integrating grammar instruction in writing instruction, Patricia J. McAlexander advocates teaching with a grammar checker, a feature available in many word processing packages available today. She provides specific examples of how to teach students to use - and learn from - the grammar checker in Microsoft Word so that it helps students improve their editing abilities and become more self-sufficient writers. Also stressing how computers can help basic writers, Judith Mara Kish counters the notion that computers isolate writers, showing how invention activities, ease of research, and peer commenting make the electronic classroom a viable and effective means of teaching writing to basic writers.

Once again, we find ourselves offering articles that reveal the basic writing enterprise as both imperiled and vitally resourceful, conscious of its legacy and resolutely forward-looking, analytically self-critical and creatively innovative. We hope you will find this issue stimulating and revitalizing as you begin a new term and a new century.

-- Trudy Smoke and George Otte 


\section{ENGAGING STUDENTS IN WRITING-TO-LEARN: PROMOTING LANGUAGE AND LITERACY ACROSS THE CURRICULUM}

INTRODUCTION: This is an invited contribution, and we give the circumstances of the invitation in place of the usual abstract. The last academic year was the first year of a major writingacross-the-curriculum initiative for the entire City University of New York. After a first round of professional development, participants asked for help addressing "language issues" - issues of student writers who are not native speakers of English (about half of CUNY's student population), who are struggling with standard English usage, and/or who are unfamiliar with the conventions of academic discourse. Faculty leaders met and agreed that the person who could best help with such issues was Vivian Zamel. She was invited to give the keynote for a faculty development event before the beginning of the spring term. The talk she gave, highly interactive and rich in examples, seemed a great success to all involved (including, as it happened, the co-editors of JBW). We asked if she would allow us to publish a version of that talk. We cannot supply, in this context, the lively interchanges with the audience (especially the "work" participants were asked to do with student writing and faculty evaluations of $i t)$, but we can offer a particularly cogent and compelling explanation of what writing-to-leam pedagogy should be and do, compelling most of all for the way it eschews abstractions and exhortations in favor of the most powerful arguments and evidence: that supplied by the students themselves.

My understanding of the struggles and successes of linguistically diverse students is informed both by my research on these students' experiences as learners and writers and by my own teaching. This work has given me insight into students' composing processes, those factors that promote and undermine their acquisition of language and literacy, their potential as readers and writers of English, and their ability to engage with the academic work they are assigned. So it is fitting to begin with the kind of reflections I regularly collect from students, reflections that contribute to my understanding of the challenges these

Vivian Zamel is Professor of English and Director of the English as a Second Language Program at the University of Masssachusetts-Boston. She teaches first year ESL composition courses as well as graduate courses on ESL Theory and pedagogy. She has researched and published extensively on the writing and learning of linguistically diverse learners, much of which she draws on in her current position as Director of the University's Center for the Improvement of Teaching. She co-authored, with UMass colleagues Eleanor Kutz and Suzie Q. Groden, The Discovery of Competence (Boynton Cook, 1993), and co-edited, with Ruth Spack, Negotiating Academic Literacies: Teaching and Learning Across Languages and Cultures (Lawrence Erlbaum, 1998). 
students face as writers in a language they are necessarily still in the process of acquiring. These reflections often focus, not surprisingly, on the constraints of using English, on not feeling free to express oneself, on the fear of being mistaken or misunderstood. The following account is revealing for what it tells us not only about this student's experiences with composing in English, but about the efforts she recognizes she must make in order to deal with what she calls the "barriers to writing" ${ }^{\prime 1}$ :

When I had decided on what I was going to write, I wanted to write right at first time. That always made me work very slowly and too carefully. Choosing the proper words, figuring out correct sentences, making up gaps between sentences which seemed jumping from one idea to another often forced me to make long pauses between sentences and paragraphs in writing. Sometimes, when I had ideas in several aspects, it took time for me to decide the right one I really want to say...As a non-native speaker of English, I have two main barriers in writing. On the one hand, sometimes, I found it difficult to get proper ideas or attitudes to comment on, to argue with, or to discuss some issues because of lacking cultural, political and American academic background. On the other hand, when I write, ideas come out in Chinese. I found the thought was limited by the language deficiency and I kept switching frequently between Chinese and English.

Here we see a number of themes that are recurrent in students' accounts: a preoccupation with being careful and choosing the right words and terms; a concern about connecting one idea with another; the difficulty of juggling and saying things correctly while generating thoughts at the same time; the pull of working in English while ideas in another language intrude; the tensions of writing about issues that assume a familiarity with and knowledge about the context surrounding these issues. This student's reflection on her writing experiences makes clear her own awareness of her difficulties, the efforts she is trying to make to address these difficulties, and her recognition that these attempts may not be successful. Clearly, this is a student who is working hard, as she puts it, "to write it right." Unfortunately, as she herself acknowledges, the texts she produces may not reflect these efforts.

While students' accounts contribute to my own theories about their writing and the kinds of instruction that is responsive to their needs, as student populations have become more diverse and as faculty have grown increasingly concerned about the challenges and tensions of teaching these students, my work has taken me beyond the 
writing classroom and has involved research into students' experiences as they enter courses across the curriculum (Zamel). As part of this research, I have asked students to write about their experiences in these courses, about what they wanted faculty to understand about the challenges and constraints they faced as learners in these classes. As I have collected students' responses, I have found that they reveal a number of pervasive themes. Students referred to patience, sensitivity, and encouragement as key factors that affected their learning. They spoke of the kinds of assistance they needed, pointing to clearer and more explicitly detailed assignments. They asked for responses to written work that both credited them for what they had accomplished and that would help them better understand faculty expectations. Importantly, an overwhelming number of students wanted faculty to know that they were all too well aware that their struggles with English were ongoing and that these struggles were likely to be reflected in their written work. This is indeed what the student's account that we looked at earlier revealed. They seemed to have a strong sense that because of the difficulties that were reflected in their texts, their struggles with learning were misperceived and the efforts they had made were underestimated. But they also expressed their hope that their work not be discounted and viewed as limited because of language issues.

Yet another source of information about students' classroom experiences have been several case studies I have undertaken. I conducted interviews with students whom I first came to know in my first year writing course and whose work I followed as these students progressed through courses across the curriculum. In addition to meeting with me, these students also wrote about their course experiences, thus producing a set of rich documents about these experiences. One of these students, Martha, a student from Colombia, majored in biology, but took a range of courses in a variety of disciplines. Contrary to what we may believe about the ability of ESL students to fare better in scientifically and mathematically oriented courses, Martha experienced the greatest sense of frustration in science courses, primarily, she felt, because of the absence of writing in these courses. Although Martha began as a first year student who acknowledged her fear of writing, she came to view writing as indispensable for learning, for thinking through ideas, for making it possible to connect what she knew with the assigned work, for letting her professors know what she both understood and was confused about, for acquiring language. When the opportunity to write for these purposes was not available to her in courses, Martha indicated that "the absence of writing took away from me the power of feeling firm, strong, present and interested in the subject matter." The following is an excerpt from one of her written accounts, one that captures Martha's sense of discouragement as she reflected on the absence of writing in one of her courses and the ways in which 
this undermined her learning and her acquisition of literacy and language. Her frustration and disappointment, I believe, are palpable.

I only heard dates and facts. Facts, dates. I reacted by sitting quiet and feeling very frustrated. I did not feel like sharing any of my opinions ... The lectures were missing the combination of creativity of my classmates' reflections. I started to lose the grounded self I carried with me from my ESL class experience. I tried several times to become visible during the lectures by letting out my voice. But I found myself lost because the lectures were without writing ... I remember that silent students in the classroom started to feel like a normal part of the lecture. Many times two or three words were my contributions in class. They were replacing the long and sometimes unclear sentences that previously in my ESL class were disentangled to reveal a powerful thought . . . My writing started to experience a metamorphosis because I was copying dates and facts from the blackboard. There was not a drop of motivation to enjoy my journey of learning. I felt illiterate at the end of the semester. I did not learn a single new word.

Note, in particular, Martha's recognition that the absence of opportunities to write in response to course issues led to her struggle with acquiring the language of that course and to a regression in her learning.

Yet another student who participated in this longitudinal investigation of students' experiences across the curriculum was Motoko, a student from Japan who majored in sociology. She, like Martha, was disheartened by courses that didn't encourage reactions to and reflections about course material and by assignments that she found confusing or vague and that provided few opportunities for engagement. But, as in the case of Martha, there were courses that invited and built on her thinking, that created opportunities for her to find connections with unfamiliar material, that allowed her to take risks with learning. The following account reflects such a context for learning at the beginning of a philosophy course:

The first day of the course, the professor gave us an ungraded paper assignment. The subject was about our image toward philosophy. On the second day, he posed the same question to the class, and started to call on the students from the first row. Since I was sitting in the left corner of the front row, he called on me by verifying my first name. I was nervous to speak up in front of everybody who I had not yet known, but because I already organized my idea and image 
toward philosophy last night in my assignment, though it is far from the fluent English, I somehow managed to bring myself to the end.

After I finished, the professor briefly summarized what I just said by using more philosophical sounding words. Then he raised two important issues from my statement and wrote down on the blackboard. I felt so delighted. I felt I was included. I felt my existence was affirmed. The reason why I was and still am hesitated to raise my voice in the classroom is because I am always intimidated by two big worries, which are "Will everybody be able to understand what I say?" and "Does my idea is important enough to be raised?" Most of the time, these two questions envelop my mind so that I cannot release my words; especially when I sense that the class circumstance is neither comfortable nor worthy enough to take the risk.

But this time, the professor displayed very warm and sensitive conduct before me. Perhaps that was a really trivial matter for other people, but because I was always worried about my English deficiency, even such a small matter became a big deal in my mind. A kind of hope was gradually growing in my mind, and I sensed that something urged me to take future chances in the class.

So much is revealed in Motoko's text: her acknowledgment of her resistance to "rais[ing] [her] voice," her recognition that her English is far from fluent, her concern that she may not be understood or that her idea may not be important, all of which, she acknowledges, often lead to her own self-censorship. Her text further points to those conditions that allowed her to transcend these constraints and concerns, so that it was possible for her to feel included and heard. Using writing as a source for exploring, in a safe way, the subject matter of the course, the teacher made it possible for Motoko to speak up in class, for she had already had an opportunity to articulate, in writing, what she called her "image toward philosophy." Drawing on and validating her attempt at understanding, the teacher proceeded to introduce unfamiliar language and concepts that undoubtedly enriched her initial understanding. Importantly, this process, which allowed Motoko to take the kinds of risks that are critical for learning, gave her to believe that "future chances" of this sort could be taken.

What Martha and Motoko have shared with me and written about, like much of what is revealed in other students' reflections, have given me insight into the academic life of these students and what we ought to be doing in both English classes and beyond. It is often assumed in many institutions, and I have certainly found this to be the case in my 
own, that the purpose of English and writing based courses is to fix students' language and writing before and in order to take on what is assumed to be the real work of the academy. This expectation illustrates the myth of transience, a pervasive belief in higher education that students' problems are temporary and can be remediated so long as other courses take on the responsibility of doing so (Rose). This expectation is based on the assumption that language is a decontextualized skill that can be acquired once and for all, an assumption that fails to recognize that it is the very contexts in which language is used that give it meaning. Researchers who study the work of courses across the curriculum point to the problematic nature of assuming that language is some fixed ability that determines and ensures understanding of unfamiliar texts and subject matter, especially when this is complicated by new language (see, for example, ChiseriStrater, Sternglass, and Walvoord and McCarthy). In describing the ways in which disciplines work, these researchers have found that the language and expectations of courses are inextricably tied to the underlying perspective and assumptions of each discipline. I have found this work instructive. But I find it even more useful to view each classroom as a culture in its own right-a culture with its own norms, conventions, expectations - and to understand that it is the process of working within this classroom that makes it possible for participants to acquire its discourse. This certainly helps explain why a student like Motoko had such divergent experiences even in courses within the same discipline, some excluding her from these courses, others inviting her to participate in and contribute to them.

It is crucial to understand that while students can certainly make progress in their English and writing classes when these courses engage students in compelling and meaningful work, and this certainly was the case for Martha and Motoko, their process of acquisition is just that, an ongoing and incremental process of approximation. What contributes to students' increasing fluency and confidence throughout their experiences in courses is their immersion in interesting and complex ideas, their engagement with rich material and discussions of texts, including their own, and the opportunities they are given to use writing and language as a means for taking risks with, formulating, and rehearsing both ideas and language. The writing that these students produce, the increasing complexity of their ideas, the new language and specialized terms they acquire to express these ideas - all of this is enabled by the conditions of each course. These students' learning and their acquisition of language are all necessarily works in progress, and to the extent that students are given multiple and ongoing opportunities to try out their ideas and language, and to get supportive and instructive feedback about these attempts, they continue to make progress. This is clearly what Martha had come to understand as she 
recognized the ways in which even one course could make her feel "illiterate" and gave her the sense that she had not learned a "single new word." This is what Motoko was suggesting as she spoke of how her ungraded paper assignment promoted her participation in class and became the basis for acquiring language particular to this course, what she called "sophisticated and philosophical sounding words."

Given that language is acquired within the context of genuine and meaningful opportunities to use that language, it is problematic to assume that students will come to courses across the curriculum fixed and ready as a result of their previous experiences in English or writing classes. Academic disciplines, even individual courses within the same discipline, use and depend on terms, conventions, and methods of inquiry that are specific to these courses. Doing well in these disciplines and learning their way of looking at and studying the world requires doing the discipline, which can only be enacted and fostered in discipline-specific courses (Elbow). It is ultimately counterproductive, therefore, to expect writing and English courses to be responsible for providing students with the various languages and multiple ways of seeing required across the curriculum.

What this means for faculty is that they need to seriously consider the ways in which their coursework can contribute to and build on the learning of students, acknowledging that this learning is a longterm and evolving endeavor that is promoted through ongoing immersion in and sustained engagement with ideas and language. This is especially the case for students for whom English is a second or third language. It is even more so the case for those students who have had limited literacy experiences in their previous schooling, whether in English or in their own language. These students, in particular, depend on the ways in which the opportunities and invitations of each classroom extend their academic and linguistic repertoires.

Specifically, what this means is that students need multiple opportunities to use writing as a way to learn rather than only as a means for demonstrating what they have already learned, both about language and about the course content. This means opportunities to write for exploring and sharing what students already know, for creating connections between what students know and the course issues, for encouraging risk-taking, for promoting active participation, for building a sense of community between students and teacher and among students. Writing-to-learn assignments allow students to explain course matters to themselves, to discover what they are thinking, to concretize for their readers and for themselves that they are thinking.

These writing-to-learn assignments can be enacted in numerous ways. Professors can assign what is called the "one minute paper" at the end of certain classes, asking students to write about one thing they learned that day as well as one thing that confused them. These 
can be the basis of future instruction. Students can be assigned notes or letters that they write to one another that explain their take on a particular problem, text, or issue. At my own institution, a number of faculty have assigned reading journals and have found them to an invaluable means for fostering students' connections with, interpretations of, and questions about assigned readings. Written reactions about the readings allow faculty to discover how students understand the texts they have been assigned, the ways in which they are connecting to and interpreting course texts, the complexities and confusions students are grappling with, the extent to which they are reading in an active and critical way.

Journal assignments can invite open-ended responses as well as offer specific suggestions for what students could do in response to assigned texts. Students, for example, can be asked to respond to a particular question posed or to relate a particular reading to another reading already assigned. They can be asked to write about what struck them or what they identified with. The following represents two such journal entries. The first was written in response to "Mango Says GoodBye" by Sandra Cisneros, a text assigned in an ESL writing course:

As someone said in class, this story was easy to read, but difficult to understand. Everytime I read this story, it gives me a different impression or image and an abstract idea. I don't really know what the author meant.

"Mango says goodbye sometimes"

This title is very funny. Is "Mango supposed to be a street name? In this section it's as if "Mango" was a human being. I wonder if "Mango" symbolizes another part of the author. A shadow of herself.

She was held captive-captive by her shadow, old morality or convention. She has been playing the role that her society or environment taught. She wanted to be free, but she couldn't. Then finally "Mango" let her go, she was released from her shadow.

Even though the story gives me different ideas, as far as the last part is concerned, my image is the same all the time. It absolutely reminds me of a play (drama) 'Et Dukkehjen' (I don't know the English title) by Herik Ibsen. This play really made waves and it was said that it contributed to the women's liberation movement.

When the main character of this drama decided to stop playing her role in the house, even though she had three children, she left home. She was fully determined not to be a doll. She wanted to be herself and free.

Cisneros also had been playing her role for a long time as 
she was her mother's "smart cookie." She will leave "Mango." She will leave home to find herself and her identity. When we see her next time, I'm sure we won't see "Mango" anymore.

The second entry was written in response to a chapter in Nisa, a text assigned in an anthropology course:

The Chapter 6 "marriage" confuse me in some vocabulary, but I understood the rule of marriage of the kungs women, and I found it strange too. I think it is unfair for the parents to chose their daughters a husband very young, if they travel with them, hunting and gathering when the childrens are little, why don't the parents keep their children with them until they are able to understand the meaning of marriage, or they are ready for it by their own, except give them away to be cared and maintained by a strange man.

I also found it touching in some aspects, for example when Nisa express her feelings about the times she was forced by her parents to live with Tashay, her husband, and she ran away many times to sleep in the bush. Also when she was living in his parents village, that she felt lonely and sad without her mother. It's was obvious that she still needed her mother's affection and care, but by that time the parents seem just to worry about somebody or a man to maintain her, not about her feelings.

Note the richness of these students' responses, the opportunity that writing has provided for making connections with the text, for revealing what these students brought to the text, for using language in meaningful ways to engage with the assigned readings. In the case of the first entry, for example, the student revealed her previous reading of Ibsen's play as well as the connection she was making between this chapter by Cisneros and one she had read earlier, "Smart Cookie." Note as well the extent to which writing allowed these students to make sense of these readings, to grapple with and get beyond the confusion and difficulty these students alluded to in their responses.

Yet another variation on journal responses that I have found particularly valuable for driving home the active nature of reading are double-entry notes. For these notes, students copy short passages of texts that had significance for or resonated for them, that they found moving or puzzling, that reminded them of their own experiences or of another course issue or text. Then they respond to these passages, and in the process of writing these responses, they literally uncover why these passages struck them the way they did. The following are examples of two students' double entry notes, written in response to 
an autobiographical excerpt by Rosa Parks assigned in a course focused on the history of racism and civil rights:

\section{Copied text}

My mother had a mind of her own. She always held to the belief that none of us should be mistreated because of our race.

In reality we had to face the fact that we were not as free as the books said. What they taught us in school didn't apply to us as a race.

\section{Reactions}

I like it because Rosa's mother was like a symbol of a life freedom! Her mind was very independent and clear in front of society. I think Rosa inherited her mother's courage. Rosa was as big as the Statue of Liberty in front of her black society that organized a boycott on December 5, after she was arrested because she opened her "eyes to the prize."

When Rosa Parks talks about AfricanAmerican, I had a horrible feeling. No other immigrants can feel about that. Think if you were kidnapped to be a slavery from your country, how difficult the situation would be? "This is not the home of the blacks" is the poem written by Langston Hughes had expressed. Rosa had showed her progressive action 12 years before she arrested. But she was taken off the bus. I was shocked by the humiliating segregation law. You have to stand up and give a seat to somebody else because you are black. What a racism! When I was in China, even though there was discrimination to the north people who came down to the south, the south people at most could call them bad names and cheat them, but could never show out.

Note the particular ways each of these students is connecting with the reading, choosing the passages that spoke to them, and revealing why they found these passages compelling. Note as well these students' references to other course readings, thus indicating how this kind of writing allows students to see course texts in light of one another. Finally, these double-entry notes reveal that students are trying out some of the recurring language of the course theme-language that had been unfamiliar to them at the outset of the course - thus dem- 
onstrating the central role that writing can play in promoting the very process of language acquisition.

It is by engaging in written responses of this sort that students begin to understand that reading is not a passive process of decoding words, but rather that it is quite literally, a process of composing. For students who are used to getting through texts with yellow marker and bilingual dictionary in hand, and who therefore are not reading in an engaged way, this is a critical insight for them to have. Note how Jenny, a student from Taiwan, reflects on the ways in which writing journal entries, a new experience for her, had made it possible for her to engage with her reading:

I have never been asked to write journal entries in Taiwan. That was why I shrank when I understood the requirements of this course. However, after trying to write a journal constantly for three months, I feel kind of interested and freer in writing ... I pay all my attention to the ideas I want to say ...

Before [in Taiwan] I forgot and threw away all the knowledge in textbooks after exams. But now when I mark or highlight some sentences that I consider important while reading, I would write down the reasons why they are important to me, I try to make connections and associations between the contents and between my experience or between one paragraph and another. I think then the knowledge in textbooks would become part of my mind finally. My brain was a temporary storehouse for knowledge before, but now it plays an active role.

I am struck by the extent to which Jenny recognizes that in order to internalize "the knowledge in textbooks," she must reconstruct that knowledge through writing. I am also impressed by her authoritative stance, one that comes through her act of authorship.

In addition to assigning reading journals, some faculty have instituted short in-class, ungraded writing to get students to think about a question posed or an issue addressed in the assigned reading. They have found that this has increased the participation of students who are troubled by the difficulty of following what is being said or who are concerned about both what they will and how they will say it. Writing done under these circumstances provides students with a safe opportunity to find their way into class discussion, to rehearse what they then say publicly in class. ESL students, or any students for that matter, who feel lost or who resist speaking in class, may be more likely to participate when they have an opportunity to write first, and when what they have written in these informal pieces are acknowledged and valued as contributions to the course. By way of illustration, I turn 
again to one of Jenny's reflections, one in which she recounts how overwhelmed she felt in courses whose primary or only activities involved listening and responding:

Because of my weak English ability in speaking and listening, I felt very frustrated and depressed when I could not understand what the professors at U Mass, Boston talked about in class. However, it seemed to be unfair to regard me as a student without any thinking ability by my external behavior. I sat silently in the classroom because I had to listen to the professors carefully and tried to comprehend. And how could I understand and respond to a topic I was unfamiliar with? I could not understand the professors' questions maybe because I did not understand the English totally or because I needed more time to think about how to answer in English. But the professors sometimes had no patience to wait for my response and then changed to the next topic right away.... I met similar problems in the group discussion. I performed awfully in my first time to share my ideas in a group. ... No complete sentence came out of my mouth, only separate English words. I got more and more nervous. When I tried my best to make English sentences in my brain, I could feel the other members were almost out of patience at that time. I lowered my head immediately and did not say a word.

However, when Jenny is given the opportunity to write in response to course issues as a basis for interacting in class, her attitude and learning undergo a transformation. It's as if her writing has given her to trust the use of her spoken voice:

I was freed and encouraged to speak out what I really wanted to say ... Also, I like group discussion more and more for we could share ideas to the same subject. I could feel that the ideas presented by me in the group discussion through my writing were taken seriously by my classmates and the professor.

With respect to more formal paper assignments, it is critical to examine the assignment itself as a source of difficulty. It is helpful to ask ourselves: What previous or underlying knowledge is assumed by either the assigned reading or writing? Am I expecting students to draw on knowledge or experiences that are unfamiliar to them? How can I know whether this is the case? To what extent have students had an opportunity to practice and receive feedback about the very kind of work that the assignment is asking for? How much guidance is provided in order to help students address an assignment? 
By posing these sorts of questions, we can begin to acknowledge the extent to which our assignments may be compromising students' writing and language ability and thus contributing to their difficulties. This is certainly borne out by our own experiences, for many of us can attest to the fact that when students are asked to write about a difficult text or to do a particularly challenging piece of writing, "things fall apart," particularly with respect to students' syntactic control. While this may occur because students are overwhelmed by the complexity of the task, another reason that accounts for writing that appears problematic to us has to do with students' attempts to approximate the very discourse of the course material we've assigned. In other words, students, distrusting their own voices and language resources, perhaps because these are rarely made room for in the work of the course, are so intent on trying out the academic language that they have been reading, that their writing appears incoherent, impenetrable even. Hence the need for students to explore the issues and use the terms raised in the readings and assumed by the assignment before the assignment is given. Hence the need to give students opportunities to write about the course issues and readings as a way for faculty to uncover misunderstandings and misinterpretations, as a way for faculty to respond to these efforts by offering instruction and support, as a way for faculty to intervene when students rely too heavily on and reproduce prematurely what students view as the authoritative language of their readings. But I want to emphasize that what I am recommending here is not just more writing, but writing of a different kind - writing for promoting learning, reflection, active engagement. It is opportunities of this sort that allow students to take risks with learning at the same time they provide us with important moments for teaching before the stakes are high, before students' work is evaluated.

When papers are assigned, giving students the opportunity to draft their texts allows students to first commit themselves to generating ideas and to thinking in complex ways. Allowing for a process of drafting and revising papers means that both we and the students need not be distracted by surface features of language at the outset, something they and we are likely to do if there is only one opportunity to submit a paper or if our feedback for revisions focuses on these concerns. My own long-term experiences as a reader of portfolios of course papers - submitted to meet the university's writing proficiency requirement-indicate that faculty, especially when they are responding to students who are struggling with English language issues, do indeed prioritize surface-level issues. Even when revisions are required, faculty heavily attend to correct language use on first drafts, often missing or ignoring larger meaning-level concerns, perhaps because these concerns are more difficult to untangle and address.

A series of related underlying assumptions seem to account for 
these kinds of reactions. Teachers may assume, for example, that students can learn from feedback of this sort; that it is the teacher's responsibility - to the student and to the institution - to point out errors first and foremost; that not pointing to errors reinforces students' problems; that learning and language acquisition are promoted when texts are dealt with in this way; that asking students for revisions based on these kinds of responses and corrections will contribute to students' understanding and progress. And yet, when I examine students' revisions (often submitted as part of their portfolios), I am struck by what I see. The texts are not much improved. Indeed, there are sections that read less coherently when students try to accommodate the changes their teachers have made or suggested. My sense is that these students have learned little in the process, except perhaps that their writing is inadequate and that they ought to find someone to edit their papers. The subsequent writing that these students do, as evidenced by other papers submitted in the portfolio, drives home the point that students' writing does not benefit from this kind of feedback.

The students' papers and professors' responses that I have studied make the case for the importance of using writing as an opportunity for teaching, for responding to students' ideas, for responding to what is there rather than just focusing on what isn't. It is in this way that students can go back into their texts and rework them in light of their readers' comments. However, I want to emphasize that in the course of providing comments, we need to work at offering responses that students will be able to read, to translate into some form of action, and to learn from. After all, students who are struggling readers and writers will have particular difficulty deciphering and comprehending the responses we write if these responses are cryptic, abbreviated, and ambiguous. We therefore need to ask ourselves: What must students already know for these responses to be instructive? What do I assume will be understood when I raise this particular question or make this particular marking or recommendation? We also need to keep in mind that because revisiting texts means that students are necessarily rereading them, students may be able to monitor some of the surface features of writing that they missed in their first drafts. By asking students to carefully review their own writing, something that unpracticed readers and writers are not in the habit of doing, we are giving them an opportunity to draw on their linguistic resources and intuitions in order to monitor and control language. This is critical especially if students have had few opportunities to read their texts carefully or to have had their texts read thoughtfully, the very situation that is perpetuated when all that students are asked to do is to insert the changes and corrections of their teachers' markings. An important finding that draws on my own teaching as well as on reports from colleagues $-a$ finding that is confirmed by a large body of research - 
is that while heavy-handed error correction may result in cleaner revisions, if revisions are required at all, subsequent new papers show little signs of improvement with respect to these features of writing. Hence the need for much less correction but more consistent error instruction. This allows both teachers and students to attend to specific, recurring features of writing, rather than feeling so overwhelmed that they don't try to address any of them.

I need to underline, however, that this approach to language issues, while more likely to encourage students to use writing as a genuine source for learning, does not necessarily eliminate errors altogether. Rather, it is more likely to contribute to the reduction of error, which is what we should be striving for. The acquisition of language, after all, is a complex, long-term, uneven, and context-dependent process, and immersion in unfamiliar language and content and ongoing attempts at language use may give rise to new, although more sophisticated kinds of errors. Thus, even though a student may have made a great deal of progress in ESL and writing courses, different kinds of error are inevitable. Note, for example, the following text written by Edwin for an ESL composition course:

Proponents of U.S. English say that they have to make English the official language because the language is the only thing that keep them together. They also say that foreign languages are in competition with the English language (acc. to Hayakawa's letter). The view the non-Speaking persons as something dangerous for this country. For example in Nunberg's reading say "In a short time, proponents say, we will have large, permanent non-English speaking communities in our midst, with the prospect of separatist movements and ensuing "language wars."

The proponents say that the government is spending too much money translating documents such as the driving tests and voting ballots. According to "Argument in Favor of Proposition $38^{\prime \prime}$ they say that "foreign ballots are discriminatory, only Hispanic, Asian American, American Indian and Alaskan native languages are targeted for special treatment in the law." In the same articles they argue that foreign language ballots are costly. In California in 1982 the cost exceded $\$ 1,200,000$

Regarding bilingual education, the reading "A war over words" says that immigrants would learn English faster if they were immersed in it and if bilingual school classes were severely cut back." In the same article McBee says that "In most states, it is possible to get a high-school-equivalency diploma without knowing because tests are offered in Spanish and 
French." In the reading "A war over words" the proponents say that "they want to halt the advance of Spanish as an alternative language and to cut back on the $\$ 133$ million spent by the federal government.

On the other hand, we have those who are fighting to keep this safe for those who haven't been born in here. One of the person against U.S. English, Joseph Trevino, says the "proEnglish move will promote racism." He also claims that "Instead of promoting the that language is, this has polarized communities." If English became the official language, that would bring discrimination against all the foreigners that don't speak English. All the program that are bilingual as in the police department, fire department and court services would be eliminated. With English as official language all the bilingual school would be closed. Nunberg argues that "the main effect would make it harder for immigrant who haven't yet mastered English to enter the social and economic mainstream." In the article "A war over words" the opponents of U.S. English think that "making English official could divide people and tarnish this nation's legacy of tolerance and diversity."

In reference to ballots, how the non-English speaking would vote if they don't understand what is on the ballots.

Also, according to "Argument against proposition 38" . . . bilingual ballots encourage assimilation by encouraging all citizens to participate in their government." About the cost of translating the ballots, this article says that the cost is minimal. For example in San Francisco they cost the average homeowner less than 34 annually. The cost is minimal so, what is the big deal about translating ballots.

The U.S. English also want to control immigration, and send back all the illegal aliens. Eventhought they have been living in the U.S. for who knows how many years. Also they're paying taxes and living like any normal American. The proponents of U.S. English, seem to me like if they've forgot how this country was made. This country was made with so many differents cultures and persons from all over the world. Why they cannot share this country with other immigrants? These new immigrant just want to find the same opportunities, freedom, etc. that the first immigrant found. These persons seem to be so selfish because they have what they want and don't want anybody else to come and enjoy this country. If English become the official language, this country would loss the sense of a free country and the land of opportunities.

Each of us could locate a number of errors throughout this text. It is important to recognize, however, that which errors we would focus 
on and how we would respond to these would reveal the idiosyncratic, subjective, and contingent nature of reading and responding to texts. Instead of focusing on these errors, I would argue that we need to note and acknowledge the academic language and moves Edwin is trying out and the risks he is taking in order to deal with the complexity of issues he is writing about. Edwin's attempt to use this unfamiliar language becomes all the more striking when we look at a text he wrote a year earlier, during his first semester at the university:

The Porto Rican culture it's distinguish by its hospitality with the turist for example. The familes are together any time. We enjoy together the traditional parties and days, like Christmas, the Holly week, mothers and fathers day.

Comparing my culture with Jill Stover whose an American, are very similar. But always no matter what culture there is an exception. This exception its the independence the youths have. The american teens to get indipendecize and to get their own money for their needs. At P.R. we don't need to. At P.R. fathers give their kids all what they need and wants and for that reason most of the kids don't adquire any kind of independence, also most of them feel isn't important for their future lifes.

My family is very union we help each other in everything, any trubble, etc. My family consist my mother, sister and I.

This student's remarkable growth as a writer demonstrates why it is critical that writing be sustained throughout the curriculum as a means for learning, as a means for trying out the discourse of an academic subject. It is in this trying out-through, for example, journal entries or through drafts of papers that are responded to in thoughtful and instructive ways - that language and knowledge are, and continue to be, acquired.

I have found it helpful in considering the work we ask of our students to think about our own apprenticeship into our disciplinespecific communities; about the kind of ongoing reading, writing, discussion that have made and continue to make our growing expertise possible; about the recursive and reciprocal way that our writing and reading build upon one another; about the continual drafting we do; about the feedback we depend on from supportive readers long before considering sending these texts off to be evaluated by readers whom we don't know; about how much writing is integral to the thinking we do, not just in recording our thoughts, but in making these thoughts possible by making them visible on paper. If this characterizes our own experiences, if we find these conditions conducive, even necessary, for our own thinking and learning - and we are already expert in much of 
what we think and write about - then it is critical to think about how these very conditions need to be enacted for students who have little understanding of and experience with this process. While this could very well apply to students whose first language is not English, it would have implications for any student whose academic and literacy experiences have been limited and problematic.

It is appropriate, given how much I draw on and learn from students' words and their work, that I close with a student's text. I turn again to Martha, one of the students who was involved in my acrossthe-curriculum case study. After reconsidering the many pieces that she had written about her courses, Martha wrote one final reflection about the process of writing these pieces. She wrote:

I became aware of my needs in classrooms by doing this across the curriculum project. Although I was a timid learner in a foreign country, I came to realize that my needs in a classroom are no different from the needs of many, regardless of their nationality and language, that making connections with the material used in class by continuously being immersed in reading and writing, supported my learning and the vision of my professors. It has been because of some professors, that I have gained understanding about the importance of homework assignments by drafting my papers and pushing my own limits. I became comfortable writing journals and exchanging papers with my classmates as a way to improve my work and also to learn with others and from others. One of the major dynamics that has supported my inner growth as a person has been the art of doing revisions of my academic work in combination with the presence that I sensed from my professors when reading my work, when they responded to my questions, observations and even silence in our classrooms.

Martha goes on to conclude this account by confirming again the central role that writing has played in her learning. In the following sentences, it is worth noting that she uses the word "metamorphosis," a term she had acquired and internalized two years earlier in a course in which she read and wrote about Kafka's work, and that she uses ellipses to punctuate, quite literally, the ongoing nature of learning. These final sentences read:

Writing about all of these experiences helped me be a resilient learner and to reclaim my voice and love for learning in a foreign country. It is like a metamorphosis with no ending ... 
Notes

1. All student entries have been reproduced exactly as they were written.

\section{Works Cited}

Chiseri-Strater, Elizabeth. Academic Literacies: The Public and Private Discourse of University Students. Portsmouth, NH: Boynton-Cook/ Heinemann, 1991.

Elbow, Peter. "Reflections on Academic Discourse: How It Relates to Freshmen and Colleagues." College English 53 (1991): 135-155.

Rose, Mike. " The Language of Exclusion: Writing Instruction at the University." College English 47 (1985): 341-359.

Sternglass, Marilyn. Time to Know Them: A Longitudinal Study of Writing and Learning at the College Level. New York: Erlbaum, 1997.

Walvoord, Barbara E., and Lucille B. McCarthy. Thinking and Writing in College: A Naturalistic Study of Students in Four Disciplines. Urbana, IL: NCTE, 1990.

Zamel, Vivian. "Strangers in Academia: The Experiences of Faculty and ESL Students Across the Curriculum." College Composition and Communication 46 (1995): 506-521. 


\title{
BASIC WRITING, CUNY, AND "MAINSTREAMING": (DE)RACIALIZATION RECONSIDERED
}

\begin{abstract}
This essay begins by using the notion of education as "white property" to explore the racialized discourses surrounding BW students. By analyzing accounts from the early period of open admissions at CUNY, it shows how students are racialized as "minorities" despite the significant numbers of whites in the program. It argues that because open admissions students embody a threat to established structures of white power and privilege, they are discursively coded as non-white.

In its next major section, the essay contends that racialization within contexts like BW needs to be identified and understood in order to truly dismantle these structures of whiteness. As a means of proving this, the essay explores two examples of discourse that is "deracialized" in some way: one pertaining to the end of CUNY open admissions, and one advocating for mainstreamed BW courses. Both examples demonstrate that by not directly addressing issues of race, structures of whiteness are ultimately left intact.
\end{abstract}

In "Race: The Absent Presence in Composition Studies," Catherine Prendergast argues that there exists a complex and relatively unexplored relationship between the field of Composition and the notion of race. Rather than dealing with the effects of race and racism in explicit, concrete ways, Prendergast suggests that much composition literature subsumes race into "'basic writer,' 'stranger to the academy,' or the trope of the generalized, marginalized 'other"' (36). And, as one searches through past issues of a journal like JBW, it seems that Prendergast's description of the trope of "basic writer" holds true: basic writing and discussions of race do often appear hand-in-hand, yet their connection is not always clearly defined.

Consider the following pronouncements drawn from JBW articles. In his 1993 piece "Basic Writing: Pushing Against Racism," William Jones insists that the term basic writer "has been used with notable frequency, as euphemism and code for minority students" (74). A few issues later, in his 1994 article "The Autobiography of Malcolm X as a

Steve Lamos is Acting Director of the Writers' Workshop at the University of Illinois at Urbana-Champaign. This article is part of his larger dissertation project which focuses on discourses of race within basic writing. In addition to this work, he is also conducting research involving discourses of science, and is co-conducting a study of ESL students in the Writers' Workshop. 
Basic Writing Text," Geoffrey Sirc declares in his opening sentence that "Basic writers are almost wholly, racially other by definition" (50). Ira Shor's 1997 piece describes basic writing as "Our Apartheid," thus not only suggesting that basic writing is the territory of racial minorities, but implying that it involves the kind of racially-sanctioned violence and hatred which apartheid entails. Finally, in the most recent issue of $J B W$, Keith Gilyard notes that BW programs consist of a "solid majority of people of color" (36).

If we take these articles as an indication, it appears as though race is a key component of $\mathrm{BW}$ discussions: each article suggests that basic writing and minority students are related in some important way, whether by euphemism, definition, or association. Yet, at the same time, much BW literature is quick to point out that basic writers are a culturally diverse group of students, and not simply people of color. In her rebuttal to Shor's "Our Apartheid," for instance, Karen Greenberg asserts that " $[\mathrm{m}]$ ost basic writing students are not 'Blacks' [referring to the language of Shor's piece]... they are ethnically and culturally diverse" (90). In their piece "Basic Writing Class of '93 Five Years Later: How the Academic Paths of Blacks and Whites Diverged," Eleanor Agnew and Margaret McLaughlin demonstrate that BW students come from a range of racial backgrounds, and suggest that these backgrounds are important to their success or failure. Even Shor's 2000 piece "Illegal Literacy" (his JBW follow-up to "Our Apartheid") mentions both black and white individuals who suffer under the BW bureaucracy at his home institution.

It appears, then, that there is a contradiction here. On one hand, the discourse surrounding basic writing recognizes basic writers as minorities; yet, BW scholars are quick to note that many basic writers do not fit this description. It is worth asking questions about why such a connection exists, and why it has become such a common way of talking about basic writing.

\section{Race and Open Admissions at CUNY}

In order to begin answering such questions, I will turn first to discourses surrounding the early stages of the open admissions program at CUNY. I make this choice for several reasons. First, open admissions is widely regarded as an important home of BW research; from the very beginnings of this program, well-known basic writing scholars like Mina Shaughnessy, Ira Shor, Marilyn Sternglass, Karen Greenberg, and a host of others have spent their energies determining the best ways to serve the influx of non-traditional writers who were entering CUNY for the first time. Open admissions is therefore a context with clear ties to much contemporary BW scholarship, and a con- 
text with which $J B W$ readers are intimately familiar. More important, though, the discourses surrounding open admissions (particularly those from the "mainstream") are rife with references to race. I will argue that these racialized discourses serve to mark open admissions in much the same way that BW discourses do; further, I will argue that by doing so, they mark the phenomenon of educational access as a distinctly racialized space.

The first examples relevant to this discussion are two well-known accounts of open admissions written by CUNY professors in the 1970s. These professors equate open admissions students with minorities as a means of justifying their opinions about who should and should not be granted access to the academy. For instance, in his 1976 work The End of Education, Geoffrey Wagner suggests that he is profoundly disturbed by the influx of open admissions students into CUNY, and implies that this discomfort is based in part upon their racial difference. At one point in his text he describes a group of open admissions students as the "senior class at Rikers Island" (132). ${ }^{1}$ Shortly after uttering this statement, he goes on to make specific comments about the racial and ethnic traits of these students, implying that their perceived criminality and background are closely intertwined. For instance, he characterizes one group of Latinos and Latinas in the following way:

I can testify that one colleague the first term had a group of Panamanian girls in [his] Basic Writing course who were so abusive, stupid, and hostile that he could conduct his classes only by ignoring their presence, as they sulked in the back with their babies. Puerto Ricans, meanwhile, demanded extra credit for having to learn the lingua franca of English in the first place (128).

Clearly, Wagner sees open admissions as a threat, as it allows these "abusive, stupid, and hostile" students (students who are clearly marked as racial, ethnic, and linguistic minorities) into the university where they would not otherwise be. It is interesting, too, to note that he dwells specifically upon the writing classroom as the context for his discomfort; in doing so, he establishes a clear link between the notion of race and issues of literacy, one which suggests that literacy is a privilege inappropriate for people of certain racial and ethnic backgrounds.

Along slightly less caustic lines, Wagner's colleague L.G. Heller writes The Death of the American University in 1973 during an earlier stage of open admissions. His discussion is similar, although perhaps it does not reject minority students as openly as Wagner's does. For instance, Heller insists that "Black and Puerto Rican students" (20) were among some of the groups responsible for the political disruptions which took place on campus, groups which also included the radical 
organization Students for a Democratic Society. Here Heller does not openly reject minority students in the way that Wagner does; however, he does subtly imply that race makes these students appear threatening, in much the same way that the political agendas of the (apparently white) radical groups makes them a threat.

Heller then offers a characterization of the open admissions program as a whole which insists that, although there is room for the

perfectly legitimate escalation of the level of aspiration of some minority groups ... the associated move toward open-admissions policies ... constitutes part of this phase of the problem, at least to the extent that the would-be college or universitybound applicants have not mastered the knowledge and skills heretofore delegated to the elementary and high school levels of education (155).

This passage suggests that open admissions is exclusively the domain of minority students when it speaks of "the legitimate escalation of the level of aspiration of some minority groups." In addition, it juxtaposes race and academic ability by suggesting that these open admissions students are simply not prepared for the university. So, while Heller does not say explicitly that minority students do not belong in the academy, he implies it when he simultaneously suggests that open admissions students are minority students, and that open admissions students are unprepared for (and therefore undeserving of) a college education.

The next piece to which I turn is Bruce Horner's "Discoursing Basic Writing," a contemporary discussion that also notes this tendency to construe open admissions students as minorities. Horner suggests that the popular media constructed open admissions students of color as both political militants and academic failures (202). He also points to several New York Times articles which single out Black and Puerto Rican students as "ignorant and disruptive," others which accuse students from these groups of engaging in the "Wrecking of a College," and still others which refer to these students as "barbarians" (203). In these ways, Horner suggests that the mainstream media in the 1970s reacted to open admissions students of color much like the two professors noted above: they explicitly identified them as minorities, associated them with ignorance and barbarism, and shunned their presence at the university level.

Horner's discussion then provides additional insight into this situation as he focuses specifically on white open admissions students, students who appear to be discoursed very differently. Horner suggests that "unimaginable within the framework [of open admissions discourse] ... were the so-called 'white ethnics': working-class whites, 
many of them at CUNY of Italian or Irish Catholic background" (202). This assertion that whites were "unimaginable" within open admissions is intriguing for two reasons. First, as Horner remarks, "the majority of open admissions students at CUNY were whites of workingclass background" (202); second, articles appeared within the mainstream media with names like "CUNY Open Admissions Found Benefiting Whites Most," and "Open Admissions Found to Benefit Whites Too" (202). These facts suggest that whites were clearly present within open admissions, and that their presence was even discussed to some degree within the mainstream. Apparently, though, because they were not the "right" color, they were still not regarded as the true population of the program. Sociologists David E. Lavin and David Hyllegard also note this paradox when they suggest that "the benefits to whites under open admissions have not generally been recognized" (34), despite occasional stories like the ones that Horner mentions.

When examined as a whole, the accounts of Wagner, Heller, and Horner all suggest that open admissions students are minority students "by definition," much like in the BW literature mentioned previously. These students are labeled as minorities and consequently determined to be unfit for college-level work. This is not to say that whites are totally ignored within accounts of open admissions; after all, they are the focus of the kinds of articles that Horner mentions. However, in these articles whites are not discoursed as "barbarians," but simply as bystanders who happen to derive benefit from a program not intended for them. In this sense, they do not constitute the "legitimate" focus of open admissions talk.

In a broader sense, then, these processes of racialization within BW and open admissions suggest that race is fundamental to issues of educational access. As multitudes of non-traditional students seek higher levels of education, they are clearly labeled and sorted according to racialized conceptions of who does and who does not belong at the university. In the process, notions of race, academic ability, and overall worth become intertwined such that minority status and remedial status become one and the same. With this in mind, I now turn to the work of several critical race scholars who highlight the connections between race and issues of power and privilege in educational contexts. This work will help to explain why such racialized discourses emerge in contexts like open admissions and BW; further, it will illuminate some of the implications that such discourses can have.

\section{Critical Race Theory and the Notion of "White Property"}

My analysis thus far has arisen from the idea that we must identify and analyze the racialization of BW and open admissions rather than leaving it unexplored. By doing this, I think that we take impor- 
tant steps toward minimizing the negative effects that such racialization can foster, particularly with regard to the sorts of racism mentioned above. This claim is similar to one that theorist Ruth Frankenberg makes as she focuses on the structural racism inherent in the concept of whiteness. She defines "whiteness" as

a set of locations that are historically, socially, politically, and culturally produced, and moreover, are intrinsically linked to unfolding relations of domination .... among the effects on white people both of race privilege and of the dominance of whiteness are their seeming normativity, their structured invisibility (6).

Here Frankenberg suggests that the power afforded to whiteness exists in its status as an invisible "default" position; because whiteness is the norm, it is unlikely to be questioned, and the structures of power that undergird it are unlikely to be changed. For this reason, Frankenberg insists that any critical examination of race must attempt to account for the power inherent within whiteness in explicit ways.

One tool for unpacking the effects of whiteness that will prove useful here is the notion of "white property," a concept which critical race theorist Cheryl Harris discusses in detail. Harris insists that notions of race and property have evolved within U.S. law such that they are inextricably linked, constituting a "racialized conception of property implemented by force and ratified by law" (1715). She suggests through multiple examples drawn from U.S. law (both past and present) that whiteness has become synonymous with wealth and ownership, while non-whiteness has come to represent poverty and non-ownership. For instance, when Harris speaks of the evolution of slavery, she suggests that whites became coded as property-owners, while nonwhite slaves came to represent a "hybrid, mixed category of humanity and property" (1718). Later, she argues that whites were legally entitled to usurp Native American lands because "solely through being white could property be acquired and secured by law" (1724). In these ways Harris suggests that whiteness has become a kind of "property" in itself, as it guarantees certain privileges and perks to its possessors, and denies the same to those who do not possess it.

Although her focus in this context is primarily a legal one, Harris does spend one section of her analysis discussing issues related to educational access: specifically, the proliferation of so-called "reverse-discrimination" cases at colleges and universities. Early in her piece, she suggests that this type of case posits whiteness and white property as a kind "baseline" against which the rights of all other groups are judged (1714). Later, she suggests that these sorts of cases provide whites with the power to determine the "extent of infringement on [their] settled 
expectations" (1768); in other words, they allow whites to determine the degree to which college admissions will reflect diversity without upsetting expectations that whites themselves will remain the majority. For support, she mentions a case in which one white student sued for admission to an elite university on the grounds that "less-qualified" minorities took the place guaranteed to him by virtue of his score on a test (1769). Harris sums up this case (along with several others) in the following way:

The underlying, although unstated, premise ... is that the expectation of white privilege is valid, and that the legal protection of that expectation is warranted. This premise legitimates prior assumptions of the right to ongoing racialized privilege (1769).

Harris' comment suggests that educational access itself falls under the rubric of "white property": whites perceive access to educational resources as an exclusive right, one which they are entitled to govern as they see fit. In this particular case, the right is manifested as a (racialized) test score which provides white students with the sense that they should be guaranteed admission to a particular school, as well as the sense that "unqualified" minorities occupy their "rightful" place. This belief is further bolstered by the fact that students are entitled to sue for this right in the U.S. legal system, and to assert that their whiteness is being infringed upon. In this sense, Harris' example suggests that education is not a neutral entity, but one which exists in a larger framework of white power and privilege.

This idea of education as white property has been employed by several other critical race scholars as well, particularly as a means of analyzing the impact of the Civil Rights legislation from which open admissions initiatives were derived. In We Are Not Saved, Derrick Bell applies this notion of white property to the 1954 Brown vs. Board of Education decision. In contrast to the traditional liberal view of this decision, one which suggests that it helped to create more egalitarian educational and social conditions for African Americans, Bell suggests that it actually served to protect white property interests. He argues that

[w] hile the desegregation debate had focused on whether black children would benefit from busing and attendance at racially balanced schools, the figures put beyond dispute the fact that every white person in the city would benefit directly or indirectly from the desegregation plan that most had opposed (107).

The "figures" that Bell refers to here include things like teacher 
salaries, school buses, new school construction, federal and state funds, and taxes (105-106), all of which would accrue to white school districts as they implemented mandatory school desegregation. This suggests that the economic benefits of forced integration were quite apparent from a white perspective, regardless of the Civil Rights agenda which this move was supposed to promote.

Along similar lines, Bell later argues that the Brown decision was not only influenced by immediate economic factors, but also by concerns over the international prestige of the U.S.. For instance, he notes that NAACP court victories must be viewed in relationship to the fact that "abandonment of state-supported segregation would be a crucial asset [in competing] with Communist countries for the hearts and minds of Third World people" (62). To put this comment in terms of the "property rights" mentioned above, Bell suggests here that the (white) image of the U.S. as protector of the free world was placed in serious jeopardy by these negative perceptions, and that white property was jeopardized as a result. Historian Mary L. Dudziak echoes this sentiment in her piece "Desegregation as Cold War Imperative." She suggests, for instance, that

as news story after news story of voting rights abuses, stateenforced segregation, and lynchings appeared in the world media, many questioned whether American constitutional rights and democratic principles had any meaning. In many African and Asian countries, where issues of race, nationalism, and anti-colonialism were of much greater import than Cold War tensions between the superpowers, the reality of U.S. racism was particularly problematic (119).

Dudziak shows here that the primary goal of Brown was to maintain the image of the U.S.. Thus, she too implies that this decision was meant in large part to protect white property interests rather than to address the injustices being perpetrated on African Americans.

Like Harris' analysis of college admissions, the work of Bell and Dudziak posits educational access as a key component of white property. Their work suggests that educational access was given to nonwhites in the hope of larger projected gains, much like an investment or an insurance policy: in the first case, Bell suggests that educational access could guarantee a certain amount of extra income to white property holders; in the second, both Bell and Dudziak suggest that educational access was offered in the hope of preserving larger white property interests against the threat of Communism. Again, then, we see that programs like open admissions exist within a racialized framework of education, one that privileges the status of whiteness over that of all other groups. 


\section{White Property, CUNY, and the Racialized Realities of BW}

At this point, I would like to suggest that the notion of whiteness as a "property right" and the subsequent manifestations of white property in educational contexts can be quite useful for answering the question of why open admissions at CUNY is racialized as a minority position. I've shown that the concept of "white property" codes the power structures of the U.S. according to racial categories, with the term "white" representing power and privilege, and the term "non-white" representing an absence of these assets. Educational institutions are definitely among these power structures, since educational access is contingent on issues of race and racism.

This line of argument suggests, I think, that open admissions at CUNY (and by implication BW) is racialized as a minority position precisely because it stands in discursive opposition to white property. Programs like open admissions and BW seek to extend the white property of educational access to underprivileged groups; in this sense, they pose a potential threat to the hegemony on which this property depends. Within this context of educational advancement, then, individual minorities are perceived as the "best fit" for open admissions/ BW discourses because they embody this threat to dismantle white property and redistribute it more equitably for all people. In contrast, white open admissions/BW students are perceived as little more than a categorical mismatch within such discourses, since they ought to possess some measure of this property in the first place. ${ }^{2}$ In this sense, the larger framework of white property does in fact label open admissions/BW students as minorities "by definition," even if a majority of them are in fact white.

In turn, I would argue that recognizing these discourses of racialization is extremely important. If we focus attention on white property in the educational arena, we can begin to expose it and thus prevent it from operating unnoticed. Rather than being satisfied with unexplored tropes, unclear associations, or hazy definitions, then, we can demonstrate just how important race is to issues of education and educational access.

We might focus, for instance, on the negative potential of this racialization. Attitudes like those expressed by Wagner and Heller are enabled to some degree by this racialized discourse if it provides a structure into which negative stereotypes of minorities can be easily fit. After all, if open admissions students are minorities "by definition," and if they are typically viewed as academically unprepared, it may be easy for some people to draw essentialist connections between race, intelligence, and overall ability. I would argue that the more we expose the mechanisms of this racialization, the more we problematize 
this larger discursive framework that makes racism appear "natural."

At the same time, though, we can acknowledge that racialization is not always a negative thing; in fact, it can serve as an important basis for resisting whiteness and white property. If we recognize that whites have access to privileges and perks that others do not, we can begin to critique educational discourses which insist that all students are the same. We can scrutinize seemingly race-neutral terms like "equal-opportunity," "democracy," and "freedom," and suggest that these terms do not apply to minorities in the same way that they might apply to whites. Or, when speaking of contexts like open admissions and BW, we can contest the white properties of "literacy," "competence," and "intelligence," and insist that mainstream white standards are not the only ones by which these ideals can be measured. Cognizance of racialization helps us to oppose the idea that whiteness ought to be an educational "baseline" against which all other groups should be judged.

For these reasons, I argue that race and the racialization of educational access must be talked about openly. Doing so will not only help us to better understand the problems inherent within this racialization, but also to understand the important social and educational realities to which this racialization points. In this way, we can both confront racism on many levels, and establish an informed position from which to critique the operation of white property on a larger scale.

\section{A Few Clarifications-Whiteness and White Property}

At this point in my argument, I want to pause and make a few clarifications. In particular, I want to address the complexities of a notion like "white property," and to explain the implications of these complexities for my overall analysis.

I do not want to give the erroneous impression that white property is something unilaterally available to whites or unilaterally unavailable to peoples of color. Because white property entails a hybrid of race and economics, it follows that only those who possess significant power and privilege truly possess white property in its fullest sense. For example, Bell notes that poor whites are barred from full possession of "white property" simply because they do not have access to the power and prestige which is essential to it. He suggests that for many whites, white property may entail little more than "[living] out the lives of the rich and famous through the pages of the tabloids and television dramas like Falcon Crest, and Dynasty" (81). In this way, Bell argues that race does not guarantee economic success. However, as Cheryl Harris notes, this does not imply that the situation of poor whites and people of color is therefore equal. She suggests that even 
poor whites retain "relative privilege ... in comparison to people of color ... whiteness retains its value as a consolation prize: it does not mean that all whites will win , but simply that they will not lose" (1758). In other words, even if privilege is not distributed to all whites on an equal basis, it is nonetheless more readily available to whites than to minorities. ${ }^{3}$

It is clear, then, that white property is a complex idea that cannot be applied reductively. Rather than confusing my overall analysis, though, I would argue that this complexity actually adds to it. As I've outlined, white students at CUNY seem to be ignored or glossed over rather than identified explicitly. We can say that these white individuals lack the resources and power to be raced as "truly" white; instead, they are treated as little more than (embarrassing) exceptions to this "natural" rule that open admissions and BW are the domain of minorities. Yet, at the same time, the situation of these whites is not identical to that of people of color within these programs. Whites seem to fare much better in these programs on the whole: they are more likely to get good grades, more likely to graduate, and more likely to obtain higher-paying jobs than their minority counterparts. In a study of BW in their home institution, for instance, Agnew and McLaughlin point out that white students have a much higher chance of passing their BW courses on the first try, and a significantly better chance of graduating within five years of beginning their degree (46). Similarly, Lavin and Hyellgard suggest that open admissions as a whole "did not entirely erase inequalities that separate minorities from whites in educational attainment and in labor-market rewards" (198).

Again, then, I want to recognize that white property is not a simple concept. We cannot assume that being labeled as white or as a person of color guarantees a particular economic or social status. At the same time, though, we should still recognize the importance of white property and its implications for educational access. ${ }^{4}$

\section{Deracialization and the End of Open Admissions at CUNY}

I have been arguing thus far that racialization is endemic to educational enterprises, and that we must work to explore the implications of this as much as possible. However, I have only focused on discourses in which race is clearly foregrounded. It is just as important to look at discourses in which race is conspicuously absent; after all, this absence can hide a great deal, and may work to further mask the operation of white property. As a means of proving this, I will now focus upon instances in which race has been omitted (either deliberately or unintentionally) from discussions of open admissions and $\mathrm{BW}$, and analyze the consequences of this omission. I begin with the 
recent decision to end open admissions at CUNY, and suggest that this decision has been enabled largely by an avoidance of race and the power structures intertwined with it.

At first glance, many of the debates over the recent decision to end open admissions at CUNY seem to treat race differently than the texts which I have analyzed thus far. Rather than making explicit references to race, these debates rely heavily on ideas like "standards" and "academic excellence." New York Mayor Rudolph Guiliani suggests that he supports the abolition of open admissions only because it will help to "restore [CUNY's] reputation as one of the great institutions of higher learning in this country" (Arenson A1). Similarly, a spokesperson for Governor George Pataki insists that "We're pleased that the board voted to restore standards at CUNY" (Arenson A1). Here both the Mayor and the Governor insist that the move to end open admissions is based only on academic standards, and hence, by implication, not on issues of race.

Other accounts pay a bit more attention to race, but even they focus most of their attention on this notion of standards. In an op-ed piece, John Patrick Diggins insists that administrators who oppose this plan are only "committed to achieving 'diversity' at four-year colleges, even though this means admitting unqualified students" (A1). Along similar lines, James Traub (author of City on a Hill, a book-length account of the problems which he perceives with open admissions) mentions in another op-ed piece that "perhaps there's an element of exclusion to these mild reforms, but it's an exclusion that is plainly good for the institution and the students" (A13). Both of these accounts do make veiled reference to race through the terms "diversity" and "exclusion," yet they do so only to characterize it as irrelevant in comparison to standards. It seems that race only emerges here briefly in order to be dismissed in light of the "truth" of the standards argument.

In one sense, all of these comments represent a mild version of Heller's argument, as they champion the notion of high standards, and suggest to some degree that racial minorities represent the antithesis of those standards. Yet, they seem much more wary of race in general, only alluding to it in off-hand ways (if at all). It seems that these proponents of the end of open admissions are engaging in what Frankenberg calls a "color/power evasive" discourse, one which "insists that we are all the same under the skin; that, culturally, we are converging; that materially, we all have the same chances in U.S. society; and that - the sting in the tail-any failure to achieve is therefore the fault of people of color themselves" (14). By simultaneously championing standards while downplaying race these proponents imply that indeed "we are all the same under the skin," and hence deny that there are structures of white power (including educational opportunity, school funding, and testing programs), which grant privileges to 
whites while denying them to others. Basic writing scholar Tom Fox puts it another way when he suggests that such claims "[reassert] a standard that supposedly existed in the past and is now threatened or abandoned, without having to deal with the fact that we now face students whose diverse histories and cultures challenge an easy sense of comparison" (41).

Several critics have insisted, in fact, that this de-emphasis on race clearly contributed to the end of the program. Journalist Richard PerezPena insists that the stance of Guiliani and Pataki allowed them to limit open admissions while simultaneously avoiding charges of racism by their opponents (B 8). Journalist Karen W. Arenson notes the presence of many protesters at CUNY board meetings who argued that the abolition of open admissions at CUNY would have explicitly racial repercussions; she also suggests that several groups such as the NAACP, the Puerto Rican Legal Defense Fund, and the American Jewish Congress had considered taking legal action against the move (A1). However, she notes that because open admissions served white students, the likelihood of obtaining favorable court decisions upon racial grounds was slim. (A1). Apparently, some groups involved in the debate did recognize this link between access to power and notions of race, even though their voices ultimately were not recognized. It is particularly ironic to note that one cause of their silence was the presence of individual whites in the open admissions program - the very same whites who had been largely ignored throughout the history of CUNY. In this case, though, they were specifically identified as "white" so that proponents could assert that such cuts were not "racist" (after all, whites who didn't "measure up" were being excluded too). This again shows white power interests utilizing notions of race to serve their own needs; avoiding or reframing issues of race here proved to be the most expedient way to do so.

For these reasons, I would argue that the implications of intentionally deracialized discourses may be just as damaging (or even more damaging) than the unabashedly racist remarks made by the likes of Wagner; whereas openly racist discourses are at least straightforward in their aims (and therefore easily identified), these discourses of "standards" attempt to re-render whiteness and the power attached to as invisible. Fruitful debate about the nature of power relationships is unlikely to take place in contexts where such discourses take hold.

\section{CUNY as Lesson for Basic Writing: Race and Mainstreaming}

In this final section of the argument, I'd like to suggest that the risks of deracialization within educational discourses are not only 
present among discussions designed to promote white hegemony. Ironically, they can also be found in discourses meant to increase educational access for all students. As a means of demonstrating this, I now turn to several well-known accounts of "mainstreaming" within the BW literature. While these approaches no doubt operate with the best intentions of BW students in mind, they exhibit a relative inattention to the racialized context of BW that might prove detrimental in the long run.

I'd like to turn first to David Bartholomae's oft-cited 1992 piece "The Tidy House: Basic Writing in the American Curriculum" in order to provide a sense of history for this mainstreaming movement. In this piece, Bartholomae makes the general claim that while BW operates with the general goal of improving students' chances of success, it unintentionally creates the very inequalities which it purports to be addressing. Perhaps the most well-known quote from this piece is the following:

I think basic writing programs have become expressions of our desire to produce basic writers, to maintain the course, the argument, and the slot in the university community; to maintain the distinction (basic/normal) we have learned to think through and by. The basic writing program, then, can be seen simultaneously as an attempt to bridge and preserve cultural difference, to enable students to enter the "normal" curriculum but to insure, at the same time, that there are basic writers (8).

Here Bartholomae suggests that basic writing creates a false binary of "basic" and "normal," then treats students according to that binary: "normal" students are provided with challenging curricula and instruction because they are assumed to be capable of success; "basic" students are relegated to meaningless skill-and-drill exercises because they are assumed to be capable of nothing more. In this sense, Bartholomae suggests that BW is itself responsible for these problems, and that it must be abolished in order to address them.

And, while it has been nearly a decade since his argument first appeared in print, Bartholomae's admonition appears quite frequently in the recent mainstreaming debate as well. For example, in his wellknown 1997 piece "Our Apartheid," Ira Shor makes a somewhat similar claim:

I see the BW/comp story as part of a long history of curricula for containment and control, part of the system of tracking to divide and deter non-elite students in school and college. The students themselves are tested and declared deficient by the 
system, which blames the apparently illiterate and cultureless victim, stigmatizing the individual as the problem while requiring BW/comp as the remedy (98).

Here Shor paints BW more as a malicious attempt at social control than as a good-hearted attempt gone awry; nonetheless, he shares Bartholomae's view that BW creates basic writers. Shor attempts to prove this by pointing to specific structures within his own institution which he deems responsible for such "containment and control." For instance, he criticizes the use of unfair assessment tools like the "infamous Writing Assessment Test" (96), and rejects the institutional structures which force students to take non-credit courses that slow their progress toward a degree (96). In "Illegal Literacy," Shor speaks of non-credit courses in greater detail through the situation alluded to earlier. He outlines the story of two women (one black and one white) who were deemed basic writers by virtue of test scores, even though they had already passed the "normal" freshman composition course without completing the non-credit prerequisite. They were ultimately forced to take the BW course for no credit despite the fact that it was clearly unnecessary (101-103). Again, Shor makes this point in order to show that BW creates basic writers out of individuals who can clearly succeed in "normal" courses.

Other well-known versions of these mainstreaming programs stem from this same premise. In their account of the mainstreaming program at South Carolina, for instance, Rhonda Grego and Nancy Thompson cite the same Bartholomae passage that I mention above, and suggest that they had grown weary of "the basic writing 'slot' and the argument that holds it in place" (62). They too agree with the fundamental belief that BW helps to foster a divide between "basic" and "normal" writers. ${ }^{5}$ Similarly, a recent account of the program at Cal State, Chico offered by Judith Rodby and Tom Fox traces its theoretical heritage to Bartholomae and "[questions] both the definitions of 'basic writers' and the effectiveness of [BW] programs" (85). They also remark that the that the term "'basic' did not describe students' practices, but operated as a construct that supported a remedial economic structure that distributed 'credit' unequally'" (85).

As a result of these fundamental beliefs, all three sets of authors propose alternatives to current BW configurations. Shor's project is entitled "Critical Literacy Across the Curriculum," and features group work, ethnographic research, and support services designed to insure that students succeed. In a recent interview with Howard Tinberg, he suggests that in his program

subject matter [should be] situated diversely and critically in the identities, interests, and conditions of the students... [this 
subject matter will be used in] a field-based, project-oriented, action-centered approach which develops critical literacy through student participation in diverse organizations on and off campus as ethnographers and writing interns (166).

Similarly, the programs at South Carolina and Cal State, Chico seek to foster literacy experiences through group work and support. Grego and Thompson's program offers a non-credit "studio" which is held in conjunction with regular for-credit freshman composition. In these "studio" sessions groups of four or five students meet with experienced instructors to discuss readings from their courses, to discuss the writing that they are engaged in, and to provide a general atmosphere of encouragement and support for one another (75-81). Rodby and Fox's program is structured similarly, as students are placed into small discussion groups dedicated to reading, writing, and thinking (91-93). Both programs offer plenty of opportunities for students to discuss their work with other students at their level in a low-pressure environment (Grego and Thompson 76; Rodby and Fox 92-93), to compare and contrast their workloads and experiences in various sections of the course (Grego and Thompson 76; Rodby and Fox 97), and to use the groups as a source for venting frustration or critiquing the academic settings in which they find themselves (Grego and Thompson 77-80; Rodby and Fox 94-95).

In this way, Shor, Grego and Thompson, and Rodby and Fox all argue that their mainstreaming solutions can counteract the ill-effects of BW programs by restructuring these programs more fruitfully. Their solutions expose students to the standard first-year curriculum while offering support mechanisms to improve their likelihood of success; they provide a for-credit context for former BW students, thereby rewarding effort and achievement on the part of students; finally, they operate on pedagogical principles that reject skill and drill type of work and in favor of contextualized and collaborative literacy learning.

\section{Race and the Question of Mainstreaming}

Before I move on to discuss these projects in light of the larger issues I've raised concerning race and property, I would like to state that there is much merit in all three plans. I find their arguments regarding non-credit courses to be quite compelling, insuring that students receive credit for their hard work makes good sense. Similarly, I find the pedagogical approaches which all three programs employ to be laudable, as they feature principles of collaboration and collegiality that are admirable bases for any writing program. I imagine that under the supervision of thoughtful and knowledgeable individuals like 
Shor, Grego and Thompson, or Rodby and Fox, all of these programs can and do serve as excellent sites for teaching and learning.

Yet, in light of the critical race perspective that I've presented in the essay, I do find myself concerned about the macro-level social and political implications of these mainstreaming arguments. In effect, they suggest that BW creates inequality through its practices; thus by removing BW, they insist that inequality is removed along with it. In contrast, though, the critical race perspective I've outlined here suggests that inequalities present in BW are largely effects of racialized economic, legal, and educational processes; thus, simply removing BW will not ultimately foster significant change, since it does not address the source of the problem. It seems that at best, then, the mainstreaming argument is focusing its energy in the wrong place. Regardless of the form of the program (traditional BW program, critical literacy program, or mainstreaming program with studio support) students will face racialized inequalities endemic to the academy.

At worst, though, there is the potential for much more than misspent energy here: namely, the "de-racialization" of discourses surrounding BW, and the subsequent problems that can arise from this. In particular, I am concerned that former BW students will be placed into mainstream FYC without recognizing the ways in which that mainstream can serve to protect white property interests. I realize of course that racializing FYC as a "white" space might raise some eyebrows, especially since all of the programs mentioned above employ critical literacy and group approaches that can certainly address issues of race and racism. While I agree that the mainstream can be made more equitable through these means, I am worried about the possibility that the mainstream will not be radically restructured in the long-term, particularly in light of the work of Bell and Dudziak. Recall that even the Civil Rights movement itself (complete with its federally-mandated attempts to restructure racial hierarchies in fundamental ways) seems to have fallen far short of complete equality for all races. I fear that FYC will likely suffer the same fate.

I think for instance of Linda Brodkey's ordeal at the University of Texas at Austin in the early 1990s, in which the introduction into standard freshman comp of material considered "too political" resulted in national outcry from the white mainstream. I strongly suspect that the outcry would not have been nearly as great had the same material been introduced into a BW course; after all, BW exists on the fringes of the academy by definition (as suggested by the notion of "white property"), and therefore is perhaps viewed as a more "proper" context for such discussions.

Furthermore, I worry that our current political situation is even less amiable than it was during the early 90s. The tenor of our time seems to be increasingly anti-egalitarian, as demonstrated by the de- 
mise of open admissions as well as by the recent moves in California, Florida, Texas, and other places to end affirmative action. Thus, the kind of outcry voiced a decade ago may be even more intense today if we attempt to radically restructure FYC. ${ }^{6}$

For these reasons, I would suggest that the critical race perspective demands that we reframe this mainstreaming debate in more racecognizant terms. Rather than asking whether BW programs should be converted into mainstreaming programs (thus posing an either/or question), we might be better off asking how any and all programs for students at risk can be best equipped to recognize the racialized context of the academy, and how they can best work to prepare students to operate within it. Among the questions we might ask are the following: In what sense do current BW programs contribute to racism? In what ways do they help students to identify racism and work against it? How might we better prepare students to recognize the functioning of race in their lives, and better assist them in dismantling white property? How might mainstreaming proposals help us to reach these goals? How might they prevent us from doing so?

In answering these questions, I think that we can profitably borrow much from the aforementioned mainstreaming approaches to $\mathrm{BW}$. Critical literacy practices can help students to identify the ways in which racialization affects them in their educational pursuits, and can help them to change their own realities; similarly, studio programs can allow students to discuss the racialized nature of their educational experiences and thus negotiate these experiences more comfortably. Yet, I think that in addition to these measures, we need to insure that our programs (in whatever form they ultimately take) clearly preserve some sort of institutional space in which opposition to the white mainstream can be openly maintained. As Keith Gilyard notes, we ought to be wary of totally dismantling old BW structures, since "any space one gets to promote agency and critical faculty is valuable territory not to be conceded" (37). As we consider ways in which BW programs can better adapt to reflect the racialized realities of the academy, we simply cannot forget the institutional dimensions of our actions.

Mary Soliday offers important food for thought toward this end in her discussion of her own attempts to improve BW conditions through mainstreaming. She agrees with many of the goals of the mainstreaming enterprise, yet notes her hesitancy to completely do away with established forms of BW. For instance, she writes that she was given a special grant to explore the possibilities of mainstreaming; from this experience, she warns that "once [a program is] no longer protected by the prestige and funding of a special grant, politics can redefine the [program's] original goals" (96). In this sense, Soliday feels that if such programs are not assured of an institutional home, they can be placed in jeopardy. She also argues that any move to restruc- 
ture current programs must be accompanied by two things: a move to firmly entrench the new programs within the academy (97), and a push to convince administrators that these programs are not meant as costcutting measures, but rather as a means of improving the education that can be offered to students who enter at relative disadvantage (97). I concur with all of these suggestions, and would further add that discussions of race and the racialization of educational access need to be made explicit within these attempts at institutionalization. This will insure that issues of race cannot continue to be swept under the rug of "standards" as they were in the case of CUNY.

\section{Carrying on Our Work}

Throughout this piece I've insisted that we take a closer look at the operation of race and racialization within the context of BW. We must recognize that our students are discoursed in opposition to the white mainstream, and we must continue to explore the effects of this process as much as we can. This is especially important for us as BW teachers and scholars. We have direct influence on the ways in which our students gain access to the discourses and knowledges that are valued within the (white) academy, and thus are in a prime position to address racial issues in a significant way. As we expose students to various literacies and discourses, then, we must teach them to recognize the role that race plays in the academy, help them to negotiate this academic environment more successfully, and ultimately give them the tools to change this environment in ways that they see fit. I think that the very fact that we spend so much time in a journal like $J B W$ discussing issues of race and racism shows our collective commitment to helping our students succeed; defining and clarifying the importance of race in the ways that I've outlined can help us to do an even better job.

\section{Notes}

1. Rikers Island is regarded as one of New York's most notorious prisons.

2. I will have much more to say about whites and white property in a later section.

3. Similarly, there might be instances in which people of color possess significant amounts of white property, particularly if their economic and/or social status is high (for example sports figures, entertainers, 
politicians, and others). Again, though, this idea of white property suggests that the experience of such individuals, while perhaps more favorable than that of other minorities, is still somehow different than the experience of whites from similar economic and social backgrounds.

4. I should note too that some of my claims about racialization may seem to rely quite heavily on essentialist notions of "white" and "black." I agree that such notions can oversimplify otherwise complex ideas if they are employed haphazardly; after all, "whiteness" and "blackness" are socially-constructed terms, and therefore open to continual interpretation and change. However, I would argue that the use of such terms is justified in part by the way in which these binaries have been employed historically in the U.S.. At some level, these binaries have been instrumental in creating racialized material realities that rely on simplified notions of race (i.e. race-based slavery). Thus, while I do not want to posit essential difference between black and white in these contexts, they have always held a great deal of significance in the U.S., and hence are still useful for describing the ways in which power is negotiated between different groups.

5. I should mention, however, that Grego and Thompson do ultimately extend this argument by taking particular issue with the way that BW programs serve to mask the "personal and interpersonal mental processes that compositionists (especially teachers of those designated as 'basic writers') engage in with student writers and student writing" (64).

6. Recent discussions on WPA-L suggest that there is a debate brewing over whether on not FYC itself ought to be abolished. My wariness of unqualified mainstreaming efforts is only further intensified by the presence of such debates. Without any sort of institutionalized writing requirement, it seems that former BW students will have even fewer resources to help them negotiate the racialized realities of the academy.

\section{Works Cited}

Agnew, Eleanor and Margaret McLaughlin. "Basic Writing Class of '93 Five Years Later: How the Academic Paths of Blacks and Whites Diverged." Journal of Basic Writing 18.1 (1999): 40-54.

Arenson, Karen. "CUNY to Tighten Admissions Policy at 4-Year Schools." New York Times 27 May 1998: A1

Bartholomae, David. "The Tidy House: Basic Writing in the American Curriculum." Journal of Basic Writing 12.1 (1993): 4-21. 
Bell, Derrick. And We Are Not Saved: The Elusive Quest for Racial Justice. New York: Basic Books, 1987.

Diggins, John Patrick. "Remedial Lessons for CUNY." New York Times 18 May 1998: A19.

Dudziak, Mary. "Desegregation as Cold War Imperative." In Critical Race Theory: The Cutting Edge. Ed. Richard Delgado. Philadelphia: Temple UP, 1995: 110-121.

Fox, Tom. "Standards and Access." Journal of Basic Writing 12.1 (1993): 37-41.

Grego, Rhonda and Nancy Thompson. "Repositioning Remediation: Renegotiating Composition's Work in the Academy." College Composition and Communication 47.1 (1996): 62-85.

Frankenberg, Ruth. White Women, Race Matters: The Social Construction of Whiteness. Minneapolis: Minnesota UP, 1993.

Gilyard, Keith. "Basic Writing, Cost Effectiveness, and Ideology." Journal of Basic Writing 19.1 (2000): 36-42.

Greenberg, Karen. "A Response to Ira Shor's ‘Our Apartheid: Writing Instruction and Inequality.'” Journal of Basic Writing 16.2 (1997): 90-100.

Harris, Cheryl. "Whiteness as Property." Harvard Law Review 106 (1993): 1709-1791.

Heller, L.G. The Death of the American University. New Rochelle, NY: Arlington House, 1973.

Horner, Bruce. "Discoursing Basic Writing." College Composition and Communication 47.2 (1996): 199-222.

Jones, William. "Basic Writing: Pushing Against Racism." Journal of Basic Writing 12.1 (1993): 72-80.

Lavin, David E. and David Hyllegard. Changing the Odds: Open Admissions and the Life Chances of the Disadvantaged. New Haven: Yale UP, 1996.

Perez-Pena, Richard. "CUNY and California Curbs: Parallels in Approach." New York Times 13 May 1998: B8.

Prendergast, Catherine. "Race: The Absent Presence in Composition Studies." College Composition and Communication 50.1 (1998): 3653.

Rodby, Judith and Tom Fox. "Basic Work and Material Acts: The Ironies, Discrepancies, and Disjunctures of Basic Writing and Mainstreaming." Journal of Basic Writing 19.1 (2000): 84-99.

Soliday, Mary. "From the Margins to the Mainstream: Reconceiving Remediation." College Composition and Communication 47.1 (1996): 85-101.

Shor, Ira. "Our Apartheid: Writing Instruction and Inequality." Journal of Basic Writing 16.1 (1997): 91-104.

-. "Illegal Literacy." Journal of Basic Writing 19.1 (2000): 100-112.

Sirc, Geoffrey. "The Autobiography of Malcom X as Basic Writing Text." 
Journal of Basic Writing 13.1 (1994): 50-77.

Tinberg, Howard. "An Interview with Ira Shor-Part II." Teaching English in the Two-Year College 27.2 (1999): 161-175.

Traub, James. "Raising CUNY to a New Level." New York Times 14 Feb. 1998: A13.

Wagner, Geoffrey. The End of Education. New York: A.S. Barnes and Co., 1976. 


\title{
Mary Kay Crouch and Gerri McNenny
}

\section{LOOKING BACK, LOOKING FORWARD: CALIFORNIA GRAPPLES WITH "REMEDIATION"}

\begin{abstract}
This article describes both past and more recent efforts by the California State University system to come to terms with "remediation" as defined by various legislative and system wide bodies. It then goes on to describe recently mandated collaborations between high school language arts faculty and CSU English faculty to reduce the need for remediation. By tracing the momentum within the CSU to reduce the number of underprepared students down to $10 \%$ of the entering first-year students by the year 2007, we show the ways in which the needs of basic writers have been defined and delineated by political bodies uninformed by recent scholarship in the field of basic writing. We then describe an ongoing outreach program that attempts to address the needs of basic writers at the high school level. By relying on a collaborative needs assessment of high school writers structured on Freirean principles of codifications of community situations by community leaders, in this case high school instructors, we document the ways in which high school professionals and university collaborators can work respectfully together to support each other in their professional efforts.
\end{abstract}

While those of us in basic writing have been absorbed by the challenges posed to basic writing programs across the nation, through the downsizing of academic support programs, as in Georgia (Singer), or in the total dismantling of basic writing, as at CUNY (Gleason; Soliday, "Class Dismissed"; Wiener), a dialogue centered on the transfer of all responsibility for underprepared college students to the high school level has been going on at both national and state levels. With the passage of Goals 2000: Educate America Act in 1994 to authorize and fund the establishment of statewide standards for $\mathrm{K}-12$, the nation moved ever closer toward a top-down curricular system, with content and performance standards stipulated for each grade level by each state's board of education. The perception, that the alignment of high school performance expectations with college admissions standards should

Mary Kay Crouch is an Associate Professor of English at Califormia State University, Fullerton. She directed the Developmental Writing Program for 15 years and currently is Coordinator of Composition. With Gerri McNenny she is coordinating the work of the CSU Collaborative Academic Proparation Initiatives Grant. She also regularly travels to Vietnam to work with teachers there who teach English. Gerri McNenny is an Assistant Professor of English at California State University, Fullerton. She currently directs the Developmental Writing Program and teaches Writing in the High Schools and basic writing. She is also involved in the development of first-year learning communities incorporating community service learning and coordinates the CSU CAPI Grant with Mary Kay. 
be the top priority for statewide boards of education, has been repeated again and again in strategy briefs and reports (See, for example, "Statewide Remedial Education Policies" and "State Strategies that Support Successful Student Transitions from Secondary to Postsecondary Education."). By increasing the stakes tied to students' performances on standardized tests that administrators assume correlate with the classroom content delivered under their statewide standards documents, state legislators and boards of education hope to preempt the admission of underprepared students to colleges.

Given the renewed scrutiny that "remedial" writing programs have been experiencing, we want to document the ways in which basic writing is perceived and dealt with at the university level in California by examining various state documents. We follow the historical development of system-wide policies on remediation, examining the complexities and contradictions of a state-mandated higher education public university system and its desire to eliminate academic support programs for underprepared college students. We also look at recent partnership efforts between the high schools and the California State University system to reduce the need for remediation and then go on to problematize the assessment of student writing the state has proposed and suggest a more credible means of forming partnerships with local high schools in addressing students' writing competence. Finally, we describe a Freirean model of community collaboration among high school and university instructors that validates and builds on the knowledge and experience of high school instructors while drawing on the specialized training that composition/rhetoric specialists can bring to equitable partnerships with our high school colleagues.

\section{The Deep Roots of EO665: 1960-1990}

It is CUNY, of course, which has made national headlines as the governor of New York and the mayor of New York City have attempted to do away with what they term "remedial" education, placing it instead in the community colleges. On the other side of the country, the Los Angeles Times has called these measures "draconian," yet the titles of two editorials it ran - "Cal State Is for College Work" (Sept. 9, 1999), and "College Is for the Prepared" (Nov. 22, 1999) - make rather clear the stance the LA Times is taking. While rightly arguing that the CUNY policy will punish students, especially minorities, for poor preparation in high school, these editorials reflect the general sentiment afloat in the state regarding remediation and the students who take remedial courses. According to the LA Times, CSU schools need higher academic standards for entering freshmen. CSU schools are not colleges of "last resort, and the system is right to demand more from students." 1 
The editorials favor what are seen as more reasonable measures being taken by the California State University system (CSU), embodied in Executive Order 665, or EO665, which was designed by the Board of Trustees in 1996 under former Chancellor Barry Munitz and went into effect in the fall of 1998 under the current chancellor, Charles Reed. On the surface this order simply requires entering freshmen to "take the CSU English Placement Test for placement in appropriate English programs/activities. .." (EO665 Memo, p.2). But EO665 is not so benign as this simple requirement seems to signal. It places testing as the lead indicator of student success and it overlooks by and large the population the CSU is called on to serve through state mandate.

Unlike CUNY, both the CSU and the University of California are bound by the 1960 Master Plan for Higher Education which remains in force. The Plan outlines the purview of the various segments of higher education in California and has been further refined by the document "The Master Plan Renewed" (1987). ${ }^{2}$ The CSU is required to accept the upper one-third of high school graduates, whether or not they are proficient in English and/or math, as long as they have a 3.0 GPA and have completed their required high school courses for admission. Students, in fact, take no test for admission. If they submit SAT or ACT scores, these are used only to place them in the proper math or English classes; the tests do not determine if students will be accepted to the university. If students choose not to take either of these exams, then they must take the English Placement Test (EPT), instituted as a statewide requirement in 1977, which determines whether a student takes a credit-bearing course in writing or not. The EPT has a writing component which is heavily weighted in the overall score. Until Fall 1998 when EO665 went into effect, the requirement that students take the EPT when they are accepted at a CSU was somewhat loosely enforced, and in some cases students did not take the EPT until well into their freshman year. Some did not even complete their lower division writing requirement until "caught" by the computer (or an alert counselor) in their sophomore year. Putting off this requirement is no longer possible under EO665; students must begin their remedial work in their first semester and must complete it within one calendar year.

The California State University system has documentation on remediation issues from as long ago as 1964 when its Board of Trustees began to question whether or not remedial activities should be part of the CSU curriculum. By 1975, the Board had decided that if remediation were needed, "instruction in the CSU shall include provision for such basic skills and remedial improvement as are necessary to provide a quality education to students who are otherwise qualified to enroll in ... degree programs," ("CSU Plan" 2). However, no credit would be given for these courses. 
In the 1980s a number of documents were produced concerning the educational quality of higher education by various committees and commissions created by the legislature and the governor. Some of these reports dealt solely with issues of remediation; others took up remedial issues only as one part of their reports. In 1982, for example, the "Statement on Competencies in English and Mathematics Expected of Entering Freshmen" opened with this sentence: "A substantial number of students who enter Californa colleges and universities are not prepared for college-level work. Deficiencies in basic skills, particularly in English and mathematics, prevail ..."(2). This report set out the skills needed by entering freshmen in both writing and reading and cautioned that the minimum requirements for high school graduation and entrance to higher education were too low. At least four years of high school English were recommended, for example. The recommendations here ultimately had the effect of changing the minimum requirements for students who planned to enter California fouryear colleges, although these changes did not alter the number of students who entered the CSU underprepared for writing.

One of the most carefully thought out and theoretically informed documents about the complexities of remediation, Promises to Keep: Remedial Education in California's Public Colleges and Universities (1983), was put together the following year by the California Postsecondary Education Commission. ${ }^{3}$ The report begins by defining terms of reference (remedial, developmental, and compensatory, among them), and it states why the members of the commission chose the term remedial. ${ }^{4}$ Looking at the issues of remediation historically, taking a quote from a 1912 issue of English Journal decrying poor writing skills and referring to the 1975 article in Newsweek, "Why Johnny Can't Write," the report asks whether remedial education should even be part of the academic enterprise of higher education.

The commission showed concern over the number of underprepared students nationwide who by 1983 had begun to enter higher education with low SAT scores and with the fact that exit exams in the California schools reflect less student preparedness than they do "local political realities" (Promises 4). Promises To Keep also recognized that remediation was not going away, but it hopefully stated that, "the four year segments should continue their efforts to maintain collegiate standards and to influence student preparation at the secondary level with the ultimate goal of reducing the need for remedial offerings" (102). While this last statement is echoed as well in later reports, prior to 1999 few funds were ever budgeted to pay either the college or secondary English faculty for programs which would provide for staff development activities. It has only been within the last year, with the latest incarnation of concern over remediation, that the chancellor has obtained funds for collaborative projects between the 
CSU and the high schools. Promises To Keep also indicates that cooperative arrangements should be set up between two-year and fouryear colleges so that the community colleges can provide "remedial activities in reading, writing, mathematics, and English as a Second Language" (102), thus relieving the CSU and the UC systems of the burden of providing remedial classes in English and math. ${ }^{5}$

Following Promises to Keep, the higher education segments were required to come up with a concrete plan for reducing remediation by 1990. The Commission therefore put out a shorter, more performanceoriented report, the "CSU Plan to Reduce Remedial Activity, 1985 1990." This report suggested, for example, that one way cut back on remedial courses was to require that students take "but not to pass" the EPT as a condition of admission to any CSU school; however, the report writers also noted that "such a policy would clearly reduce the admissions pool well below the upper one-third of high school graduates called for in the Master Plan. CSU does not have the authority to make such a determination on its own" $(1984,19)$. In fact, the CSU cannot act unilaterally on any policy affecting admissions to its schools. The Master Plan stipulates that students in the upper $12.5 \%$ of their high school graduating classes are eligible for admission to the UC system; those in the upper $33.3 \%$ are eligible for the CSU; and anyone over the age of 18 is eligible for the community colleges, in effect making these colleges our open admissions schools in higher education.

In an attempt to cut back on remedial activities by the CSU system, the following initiatives were suggested by the "Plan":

- raise the number of courses students would be required to take in high school as prerequisites for entry into the CSU;

- carry out diagnostic testing in the high school to alert students to their deficiencies;

- improve pre-service teacher education;

- institute discussion between high school and university faculty regarding competencies required for admission to the CSU; and

- set up cooperative "arrangements" with the community colleges to teach remedial courses on their campuses.

The report projected that by 1990 -just five years later - " $88 \%$ of regularly admissible CSU first-time freshmen will demonstrate competence in writing on the EPT. .." (32). Since in the 1983-84 school year nearly $52 \%$ of first time regularly admissible freshmen could not demonstrate competence on the EPT, a decline of those needing remediation to $12 \%$ in just five years would represent quite a significant reduction. However, the targets set were "modest" in the beginning (the 
commission's term) from 1986 - 1988, but accelerated for the following years. Ironically, this follow-up report to Promises to Keep attempts to drastically reduce remediation within a period of five years, while Promises clearly states that remediation is "a problem of enormous magnitude and complexity in need of long-range solutions rather than shortterm holding actions" (10). The five-year time line, however, had little noticeable effect on student preparedness. While the CSU universities worked to follow what the 1984 report recommended and the system and the state seemed to insist on, the recommendations were not strongly enforced. And other issues presented themselves.

\section{Where EO665 Is Taking Us: 1994 to the Present}

What happened between 1984 and 1994? California went into a deep recession and severe cutbacks were made in classes and the faculty who taught them. By 1994, however, we were coming out of the hard monetary times, and we had a can-do Board of Trustees who were ready to respond to what they perceived as an educational crisis in California. Tests continued to show that students entering the CSU system were poorly prepared for writing and math, and those percentages had not changed much since $1984: 51 \%$ who entered the CSU had to take some sort of remedial course in writing. A report by the Academic Program Improvement Workgroup on Support for Underprepared Students ("API"), published in 1994, noted that "enrollment in remedial/developmental (including ESL) courses in the CSU continued to grow in the late 1980's [and] a reexamination of remedial enrollment in 1990-91 showed numbers still on the rise" (3).

This report, like Promises to Keep, was written by faculty who were knowledgeable about students who lacked the background they would need to perform successfully at the university. It defines the student who is "underprepared" as "one who requires additional academic work in order to be able to perform at a minimal level in university GE and discipline specific courses" ("API" 4), but it takes issue with such an easy definition: Does the problem for this underpreparedness reside in the student or in the university? If the student is underprepared, then actions, such as requiring remedial work or denying admission to students not ready for university work, are necessary. If, however, the university is underprepared, then remedies, such as providing "specialized courses aimed at expanding non-standard English competencies" and providing auxiliary services for the students need to be in place: "In such a formulation, the University would act as a community welcoming these individuals (who we say are admissible, anyway) and seeking ways to make them successful members of our community" ("API 4). The API Faculty Workgroup reacts to the issues 
around underprepared students both intellectually and sensitively. The reports that followed this one seem not to know what this group set out, or they chose to ignore many of its recommendations.

The problem of underprepared students was placed squarely with the students in the 1995 report by the Committee on Educational Policy. The chair of that committee and a member of the CSU Board of Trustees, Ralph Pesqueira, a restaurant owner from San Diego, led a nearly one-person crusade against remediation. He headed another group of trustees which held meetings at several CSU schools to hear what students, teachers, and the general public thought about the basic skills crisis. From these meetings came a report in which some heavy-handed suggestions were made. While these proposed changes have not been implemented, primarily because of the constraints imposed on the CSU by the Master Plan, they provide some chilling portents for what might still be attempted by this board of trustees. For example, the Board had intended that by Fall 2001 all entering freshmen with few exceptions would possess what they call "basic skills," a term which they do not define and which may refer simply to placing commas and periods in the right place. ${ }^{6}$ First time freshmen would submit results of a basic skills assessment before registration, and these results "may require enrollment in a basic skills course before registering for their first term" at a CSU campus ("Subcommittee," emphasis added, 5) a plan which would send students to community colleges prior to their enrolling in a CSU.

There was even talk of requiring students to take the ACT or SAT, so that these scores would be available for all students who applied to the CSU. Neither of these exams has a writing component, as does the system wide English Placement Test. Development of an "experimental competency-based admission program" ("Support" 8) in which students would be required to meet certain performance criteria by the time they graduate from high school is looming on the horizon, although it has not yet been implemented. The Stanford 9 exam, a standardized test developed by Harcourt Educational Measurement and adopted statewide to test students in grades 2 through 11, appears to be a means to put such criteria in place. This test is already being suggested as a way to give cash rewards for schools whose students are successful on the exam, to decide on merit pay for teachers, and to determine advancement of students to the next grade. Governor Gray Davis is even suggesting that he will award $\$ 1000$ college scholarships to students who score in the top brackets of the Stanford 9, the standardized test that assesses how well students have met grade-level standard, although the test has proved problematic in California due to a lack of alignment between the state curriculum and the content tested for on the exam. 
For the follow-up report, published in July of 1995, the other requirements proposed by the committee appeared to administrators of university writing programs to set out expectations that could hardly be met. Here is one example: Until Fall 2001, the committee recommendation stipulated that students whose scores indicated that they must take remedial course work would be required to begin their remediation in their first term of enrollment "so that they will be able to perform at acceptable levels in General Education courses" ("Report" 10). However, after that date, incoming freshmen would not be admitted to the university "if they require remedial study" (10). It seems that the Board of Trustees was thinking along the same draconian lines as those responsible for CUNY's changes in remedial policytheir corporate version uses the phrase "expedite [students'] acquisition of basic skills" - , even if, in the end, they were prevented from enacting them because the proposal went against the Master Plan. ${ }^{7}$ Sensibly, this proposal was transformed in the final version of EO665, so that the following statement has become the one which all CSU schools are required to follow: "[B]y fall 2001 key implementation components, e.g., standards, assessment, early intervention, will be in place leading to the expectation that by fall 2001 there will be a 10 percentage point decline in the number of regularly admitted new freshmen needing remediation ... and that by fall 2007 no more than $10 \%$ of these students will require remediation" ("Precollegiate" 6). Those of us administering writing programs gave a collective sigh of relief. We had time to re-examine our programs and effect changes that might be needed.

First time freshmen are now required to take the English Placement Test (EPT) once they are accepted at a CSU school and to begin remediation in their first semester. Students cannot wait a semester or two, or even a year or two, before they begin their writing courses, which has happened in the past. This requirement is one that writing program administrators have no quarrel with, since we know that students should begin writing courses as soon as they enter the university. However, with 22 campuses forced to meet this goal in Fall 1998, we all had to scramble to find instructors. At Fullerton, for example, we went from 23 sections of Developmental Writing in Fall 1997 to 50 sections in Fall 1998. This hiring dilemma was especially acute in the greater Los Angeles area where six campuses needed far more instructors than they had ever hired previously, Fullerton among them, and we were often drawing from the same pool of adjuncts. These adjuncts had more teaching that fall than they could handle. Yet the $L A$ Times editorial titled "College Is for the Prepared" implied that the focus on remedial education was "draining professors' time." In reality on our campus, Gerri McNenny was the only full time faculty member who taught one of those 50 sections at CSUF that semester. The 
Times failed to note later that many of those instructors who were hired to meet the greater number of remedial sections of writing were quietly let go in the spring when the number of sections was reduced by over half.

Students must complete their remediation within one calendar year or they will be disenrolled from the university. Cal State Fullerton disenrolled 3\% of the first-time freshmen who enrolled in Fall 1998 and had not completed their remediation by Fall 1999. This figure was $7 \%$ system wide. These figures indicate that $97 \%$ of those needing remediation at CSUF were successfully remediated under the one-year mandate. In fact, this percentage held true for our Developmental Writing Program prior to the institution of EO665. We continued to do well those things we had been doing well all along. Whether setting deadlines will ensure the reductions in remediation that the board is demanding over the next seven years remains to be seen, but several realities argue against the board's optimism. Right now California ranks about $10^{\text {th }}$ from the bottom in per pupil expenditure; a nine million dollar influx of money for collaborative projects between high schools and CSU schools cannot quickly change years of low state expenditures on education. When one considers that California is probably one of the most ethnically and linguistically diverse states in the country, that many of its students do not have the advantage of wellsupported schools, that English classes range in size from 35 to 45 students, and that five such classes are assigned to teachers each day, how, then, will these mandated changes be effected? An ironic note here: our current chancellor, Charles Reed, whom the LA Times affectionately dubs the "Vince Lombardi of higher education," wants to continue to increase the numbers of students who enter CSU campuses in the next 10 years to accommodate the influx of students now arriving on campuses with Tidal Wave II. Also referred to as the "Baby Boom Echo" by the U.S. Department of Education, this surge in the school age population is predicted to add 428,000 students to California's public schools by 2009 (LA Times 8/20/00,33). EO665 has Reed's blessing. Can he-and we-have both diversity and access at the same time, given the reduction in remedial programs proposed by the CSU trustees?

\section{E0665: The Rhetoric of Access with Diversity}

Throughout the reports generated by the state and/or the CSU over the past 40 years, one of the issues bound up with remediation deals with providing access for the students the CSU is required to serve under the Master Plan. EO665, the latest directive, does not exclude anyone who meets the basic requirements for admission. In fact, 
the order reads as follows: any student who enrolls as a freshman and cannot show "requisite competence" in written English must take "appropriate remedial or developmental programs/activities during the first term of enrollment and each subsequent term" until competency has been demonstrated $(E O 665,9)$. However, it does stipulate that time limits should be established, and students "who are not making adequate progress in developing foundational skills [should] consider enrolling in other educational institutions as appropriate" (9). As noted earlier, the limit is set at one year; by that time students must be ready for the credit-bearing course in writing or they will be disenrolled from the university. The LA Times front page headline regarding enforcement of this limit was titled, "Cal State Boots Students Weak in Basic Skills", and it quoted Chancellor Reed as saying that the CSU wants to be "firm and fair. ... The message is that we mean business" (November 18, 1999 1).

However, this "business" is not neutral. It affects thousands of students who apply to the CSU. When the Master Plan was developed and went into effect in 1960, California had a fairly homogeneous population, the largest percentage being white, native English speakers, many of whom were able to afford a college education. By 1987, when the Master Plan was reviewed, that population had changed dramatically and the report takes note of this fact in its section titled "Toward Greater Equity." The commission stated that to achieve educational equity, the campuses should work toward increasing on campus the numbers of "minorities and women students." Their report also states that remediation "is essential to retention" (27), although the members of the commission are careful to specify that both the UC and the CSU must "establish and maintain clearly defined academic floors below which they shall not offer remedial courses and they shall eventually phase-out [sic] remedial instruction, other than that required for reentry students, as preparation of students by the public schools improves" (emphasis added, 28). Here again one finds a recurring theme from the 80 s on: remediation can be tolerated but only for limited periods of time. When remediation is thought of simply as a term rather than as a population of students, limits for it are easy to set.

In 1987, when Mary Kay Crouch was administering the Developmental Writing Program at CSUF, many of the students who took the course were non-native speakers of English, primarily Vietnamese. Like many other campuses in the system, Fullerton has no ESL program, so students in need of language development, and perhaps needing to develop their writing skills as well, are funneled into the remedial course. As demographics began to change, more and more students-often the first in their families to attend a university-came from the large Mexican American population that lives in Orange County. ${ }^{8}$ Similar situations existed at other CSU campuses, especially 
at CSU Los Angeles and San Francisco State which serve large urban populations.

Min-Zhan Lu and Bruce Horner point out in a recent article that "institutions across the nation expect to serve a new student body in not only race and ethnicity but also economic class, gender, sex, age, and educational or work experience" (43). This is certainly true of the CSU system and its stated policy which intends to "maximize access to a university education guaranteed by the Master Plan, and ... promote excellence with diversity within the student body of the CSU" ("Brief" 2). However, their diversity is acceptable, it seems, only if they can turn themselves into what the university sees as the right kind of students, ones who need no real help beyond financial assistance once they are accepted. Lu and Horner argue that the theory and praxis which has developed from Basic Writing as an area of study "can provide insights on how to improve student retention, especially the retention of those students who have taken seriously our catalogued expectations of diversity ..." (48).

Unfortunately, boards of trustees do not look at this research, and few if any who carry out research on Basic Writing are asked to sit on state commissions and committees which make decisions affecting the students who take Basic Writing courses. The CSU Board of Trustees has bought into the notion that the barbarians-these diverse students who represent "a source of great pride" - are at the gates when it says that providing courses in "precollegiate skills ... threaten the university's ability to offer undergraduate instruction at a level that will prepare a competitive workforce and an enlightened citizenry" (emphasis added, "Item" 3). The Institute for Higher Education Policy, which published a report on college remediation in 1998, argues that remediation for three centuries has been and still is important to the enterprise of higher education and that it will continue to be so as colleges and universities educate more and more students who want to pursue college degrees. In fact, the report states flatly that remedial education "will continue to be a core function of higher education for the foreseeable future" (6). If this report is correct, then the university must look at all of the students, including those of different ethnicities, races, and economic levels, who meet its admissions requirements as the future competitive workforce and enlightened citizens it seeks to educate.

The report which the Board of Trustee's Subcommittee published makes the point that the CSU is committed to equity and diversity and describes the CSU as a system "open to students from all social and economic backgrounds, [which] enrolls the most culturally diverse student body of any senior college system in the nation, a student body that closely mirrors the diversity of California's population" ("Precollegiate," Attachment B, np). But while the Board of Trustees 
takes pride in this, it is of two minds about the situation. On the one hand, it applauds diversity; on the other it wants to homogenize the population the CSU serves by greatly reducing the kinds of courses which will serve students who bring diversity to the campuses. One cannot argue that it is a good thing when nearly $50 \%$ of entering freshmen need remedial course work in English, especially when the students themselves are unhappy when placed in such courses. However, when faculty respond to the question of remediation by saying that they are concerned that they can "no longer conduct many undergraduate courses at a level that fully reflects collegiate expectations" ("Item," 3), one has to wonder if these professors are decrying a lack of student skills or the increasing numbers of students who look very different from the largely white male professorate. As Mary Soliday writes in a forthcoming essay, the university seems to have a "need to admit a new population of students without transforming the traditional college" ("Ideologies of Access"). Alexander Astin puts it less subtly: "If bright students enroll at our institution and take our classes, this reflects well on our own brightness.... [I]f our students are not so smart, then this reflects poorly on us" (3). In other words, the logic that drives the CSU report on remediation seems to dictate that we should only admit students who already know what we will teach them.

\section{"Remediation": Where High School and College Standards Meet}

We turn now to the logical alternative to providing academic support to underprepared college students - that of preempting any such need by addressing students' academic preparation at the high school level. Indeed, the need to strengthen high school students' college readiness had been anticipated at the national and state levels many years prior to the imposition of Executive Order 665. As mentioned earlier, in 1994 the federal government passed Goals 2000: Educate America Act, a piece of legislation that formally called for state and local school districts to develop statewide standards for schools in a "top-down and bottom-up" effort by supporting school reform at the state and local levels through the use of federal grant money. (Bodell; Goals 2000 2). Part of the overall reform effort advocated in that document called for improved teacher education and collaboration between local school districts and colleges and universities to articulate performance expectations for students and to align curricula so that students arrived at institutions of higher education fully prepared to succeed. The results, the Goals 2000 report issued four years later tells us, are promising: "schools and school systems are organizing themselves around teaching and learning to high expectations, and students are 
beginning to meet these high standards" (2). Others, however, are less sanguine about the imposition of statewide standards. ${ }^{9}$

Coming at the issue of student achievement from another angle is the "Statewide Remedial Education Policies" report, issued in 1998 by the State Higher Education Executive Officers (SHEEO), "a nationwide association of chief executive officers serving statewide coordinating boards and governing boards of postsecondary education" (SHEEO). In that report, Edward Crowe, Senior Associate Director at the Arkansas Department of Higher Education and a member of the team conducting the nationwide study of remediation policies in the 50 states, recommends the establishment of K-16 partnerships as a more effective, systemic approach to addressing the needs of underprepared students. The conclusions reached by many states participating in the study are that K-16 partnerships are a key component in identifying and addressing students' needs, with universities and colleges working with local school districts to implement "comprehensive studies of remediation and its causes, formal partnership structures that run across education and higher education systems within [those] states [with K-16 partnership programs] and new policies to deal with remediation issues at all levels of the K-16 system." (Crowe 6).

In step with these moves toward statewide standardization and curricular alignment between the high schools and colleges, the CSU Committee on Educational Policy, in its report on "Precollegiate Skills Instruction," saw as a key component the need to strengthen the academic preparation of CSU first-year students through a number of initiatives, including the need to work together with the K-12 system to "intensify and expand CSU's work with elementary and secondary schools . . . to ensure that students arrive ready for college" ("Precollegiate Skills" ). Here the CSU listed a number of strategies needed to achieve the goal of a decreased need for remediation. These include, among others, the following:

Develop assessment and intervention programs that would help determine the skill levels of high school students with the intent to identify the remedial and developmental needs of college-bound students early enough to address them while the students are still in high school.... Expand the use of CSU students as interns to provide assistance to skill instruction in middle and high schools. ... [and] communicate CSU collegiate skill standards and expectations clearly and early to students, parents, schools, and communities." ( "Precollegiate Skills" )

With a new infusion of funds from the legislature, the CSU system is 
now able to fund various initiatives to implement their plans for reducing remediation at the college level.

\section{CSU's Solution to the Remediation Crisis}

In the fall of 1999, the California state legislature provided the CSU system with nine million dollars "to work collaboratively with selected California high schools that send the most students to CSU who need remediation in English or mathematics, or both" (Spence). The call for proposals to implement the CSU-High School Collaborative Academic Preparation Initiatives (CAPI) was sent out with the express purpose "of reducing the need for collegiate-level remediation andof assisting high school efforts to apply new content, performance, and graduation standards," California's newly adopted Content Standards. The intent of the initiative was laudable: "to clarify and bring into closer alignment CSU academic preparation standards and high school content and performance standards" (Spence). In effect, the state and the CSU system provided a funded mandate to extend the dialogue between public high schools and institutions of higher education for the purpose of meeting mutual goals.

With the call for proposals for the Collaborative Academic Preparations Initiative, we see a well-intentioned alignment of the various components surrounding college readiness - that of high school content standards, performance standards, and college entrance requirements. Through K-16 partnerships, both universities in the CSU system and the high schools hope to articulate and clarify for students, parents, and administrators alike the ways in which students can better prepare themselves to meet the challenges of college. What we must ask ourselves is whether the means for the assessment of college readiness truly measures students' achievement.

In the instructions given to applicants of the grant proposal, the assessment of the success of the CSU/High School Collaborative Initiative in "preparing students for college" is directly tied to students' success on the English Placement Test, the most heavily weighted part of which consists of a timed impromptu writing assessment instrument in which students are given 45 minutes to respond to a previously unknown topic. Moreover, in the evaluation component of the grant, CSU administration officials state that "Growth in writing skills [for students participating in the grant initiative] will be measured using services of the CSU/Diagnostic Writing Service," an online counterpart of the English Placement Test that duplicates the conditions of the EPT.

Even more revealing is the assessment of participating high school teachers and what they learned from the collaboration. The conditions 
of the CSU/High School Collaborative Grant state that all participating teachers will be assessed by a combination of questionnaire and interview. All teachers who attend the "College Preparatory Institute" colloquium will complete a questionnaire focused on teachers' familiarity with the CSU/Diagnostic Writing Service. One or two teachers from each school will be randomly selected for follow-up, in-depth interviews about the teachers' curricular decision-making. At the end of the school year, the participating teachers will complete a second questionnaire focused on the extent to which they will use the CSUDWS in the future and what they learned from the EPT workshop. (Grant Proposal 5).

What is most striking in the layout of the grant, in the instructions given to each CSU campus, is the assumption that enriching the high school language arts environment and supporting teachers in the teaching of writing is synonymous with the assessment provided by the use of a single timed impromptu writing sample and the instructors' understanding of the demands of that instrument of assessment. For years, the use of the timed impromptu essay test as an accurate indicator of students' writing competence has been roundly challenged (Shor; Gleason; Soliday; Lewiecki-Wilson and Sommers). As far back as 1977, Mina Shaughnessy challenged the adequacy of timed writing tests as placement instruments. The absence of an authentic rhetorical situation, along with the artificiality of responding to a prompt on a topic that may be of little interest or for which the student possesses little background knowledge, all conspire to create an awkwardness within the writer that many find hard to overcome. As Shaughnessy put it, "Without strategies for generating real thought, without an audience he cares to write for, the writer must eke out his first sentence by means of redundancy and digression, strategies that inevitably disengage him from his grammatical intuitions as well as his thought" (82).

Another factor that comes into play in the staging of the timed writing test is the degree to which the test mirrors a student's sense of ease in participating in a typically middle-class Western pursuit, advancing his or her point of view authoritatively. As Tom Fox points out, "These [placement] exams test both writing ability in a timed-test context and the degree of comfort and authority that students feel in such circumstances. This second fact may be the reason for the higher representation of socially marginalized students in basic writing programs" (73). If students have been schooled in environments that fail to emphasize that sense of authority and voice, as is often the case in working class and lower income schools (Anyon) or in different cultural contexts, then student performance in timed writing situations may fail to measure up to the tacit expectations of test readers.

The most compelling criticism of a heavy reliance on the timed 
impromptu writing test as the measure of writing competence comes from nationally recognized authorities on writing assessment, the Conference on College Composition and Communication's Committee on Assessment. In 1994, the committee released a position statement articulating the professional stance of the CCCC on this issue. In addition to acknowledging the social and contextualized nature of language usage along with the importance of authentic rhetorical situations in writing assessment, the CCCC Committee on Assessment also noted the limitations of a single timed writing evaluation instrument by asserting the following:

... any individual's writing "ability" is a sum of a variety of skills employed in a diversity of contexts, and individual ability fluctuates unevenly among these varieties. Consequently, one piece of writing-even if it is generated under the most desirable conditions - can never serve as an indicator of overall literacy, particularly for high stakes decisions [such as admission and placement]. Ideally, such literacy must be assessed by more than one piece of writing, in more than one genre, written on different occasions, for different audiences, and evaluated by multiple readers. This realization has led many institutions and programs across the country to use portfolio assessment. ("Writing Assessment")

While portfolio placement may not be a viable option for placement in the CSU, due to the costly and time-consuming process, many universities have moved to portfolios as a valid means of placement, including the University of Arizona, Miami University of Ohio, and others (Borrowman; Sommers, Black, Daiker, and Stygall; Yancey and Weiser).

More to the point, we were concerned with the impact that an emphasis on timed impromptu writing tests would have in the classroom, on the curriculum and on the energy spent preparing for them. Cynthia Lewiecki-Wilson notes that no matter how process-centered the writing class may be, if students must do well on a timed writing test, "producing a single piece of writing with no chance for revisions, then a pedagogy emphasizing a few narrow forms of argumentation and surface correctness prevails" (Lewiecki-Wilson and Sommers 448). By limiting course content, she argues, the test, along with the practice of teaching to the test, hardly encourages students to make a commitment to literacy as a lifestyle that in the final analysis is what truly prepares them for college. With these considerations in mind, knowing the research and scholarship surrounding the timed impromptu writing test, we set out to structure equitable and informed partnerships with our local high schools. 


\section{Establishing Equitable Partnerships}

High school/university partnerships hold enormous potential, yet the dialogue that exists at present between many high schools and local universities is often vague at best, at worst condescending and disparaging of the efforts that high school English teachers make in preparing students for college writing. Too often universities fail to work equitably with high schools, and the potential dialogue between the two levels of education breaks down at a number of points. Universities often fail to communicate the expectations for writing proficiency and critical thinking which vary from institution to institution. At the same time, high school English instructors rarely receive any feedback about which students succeed at the college level. While they are generally well prepared to teach literature, many teachers have not received any concentrated preparation for the teaching of writing. Nor is there always a clear correlation drawn between the work a student does in high school English classes and the success he or she experiences in college-level writing courses and on placement tests. To those outside the educational system, the most visible sign of the gaps in teachers' and students' understandings of expectations for writing competence are evident in the placement results. In the CSU system, the most recent statistic shows that $47 \%$ of all eligible students ranking in the top two-thirds of all high school students place into what is commonly referred to as "remedial writing" after taking the English Placement Test ("CSU Remediation").

Given the parameters of the CAPI Grant, in which every measure of success is tied to the results of a controversial placement instrument and in a situation in which a top-down relationship has traditionally existed between universities and high schools, we decided to do our best to work around these conditions. We set out to prioritize those issues that we felt were most conducive to overall gains in writing competence and literacy and in establishing equitable relationships with the participating teachers at the four high schools that had chosen to work with us on this project. We both believe that any successful collaboration between universities and high schools must recognize and materially validate the professional status and expertise of high school teachers while at the same time making available to them our own expertise in Composition and Rhetoric. For these reasons, we chose a Freirean model as the basis for the framework of our joint efforts, which emphasized the high school community's role in problem identification, problem solving, and collective action. We felt strongly that in order to have any positive impact on students' writing and teachers' knowledge of writing instruction, teachers had to have a major role in articulating what their students' needs were and in determin- 
ing how to address those needs.

One of us, Gerri McNenny, was first introduced to the principles of Paulo Freire's work, not through the reading of his theoretical works, but through the implementation of those principles while working in the Peace Corps. The essence of Freire's approach to community work, it seemed at that time, emphasized the need to rely on the people living in the midst of a situation to codify and problematize that situation for themselves. Their ability to "name the world," so central to Freire's approach to community work, was the single most important factor in their sense of empowerment and their ability to act in that particular context.

As we set out to design a high school/university partnership, we saw these same conditions as necessary to the success of any joint venture. Despite the complexities of Freire's theoretical framework, we still believed that a Freirean model of community work would be the most appropriate approach. As Denis Goulet notes in his introduction to Education for Critical Consciousness, Freire clearly understood the adaptive nature of the liberatory pedagogy he sought to interject into the communities that he and his fellow cultural workers lived in:

Paulo Freire's central message is that one can know only to the extent that one "problematizes" the natural, cultural and historical reality in which s/he is immersed. Problematizing is the antithesis of the technocrat's "problem-solving" stance. In the latter approach, an expert takes some distance from reality, analyzes it into component parts, devises means for resolving difficulties in the most efficient way, and then dictates a strategy or policy. Such problem-solving, according to Freire, distorts the totality of human experience by reducing it to those dimensions which are amenable to treatment as mere difficulties to be solved. But to "problematize" in his sense is to associate an entire populace to the task of codifying total reality into symbols which can generate critical consciousness and empower them to alter their relations with nature and social forces. (ix)

This reflective group exercise is achieved only if participants experience their roles in the dialogue as pivotal to the transformation of their situation. By doing so, community members, in this case high school professionals with ample experience and education, "become transforming agents of their social reality. Only thus do people become subjects, instead of objects, of their own history" (Goulet ix).

With these rather high ideals in mind, we collaborated with high school participants to design a needs assessment questionnaire to identify and codify site-specific issues and to initiate a dialogue among 
ourselves for the purpose of improving and encouraging students' reading and writing. We invited high school teachers who wished to participate in the collaborative project to come talk about their perceptions of students' impediments to improved writing and literacy and to identify strategies for addressing their needs. We also asked high school professionals to identify for themselves what they believed would be appropriate roles for university collaborators to play in working with high school instructors. We attempted to leave the dialogue as open-ended as possible.

As we met to identify and discuss key issues, what really impressed us was the incisiveness of our high school colleagues' observations. In their responses to the needs assessment, they identified key impediments to student progress and preparation for college level writing. They determined what kinds of collaboration and intervention would work best for them in their contexts, and they let us know exactly what they needed from us as university colleagues to help them improve student writing.

Among the hurdles they face, high school teachers noted class size as the foremost, with 38-40 students per class, with five sections per day, for a total of 200 students contacted each day. As a result, teachers have no time to talk individually with students about their writing. Moreover, assuming that each essay can be read and commented on in a fifteen- to twenty-minute period, if a teacher assigns one essay assignment to her classes, that two- to three-page assignment will take each teacher from fifty to sixty-six hours to grade. This work is in addition to a full week of planning classes and teaching five sections per day. Thus, high school English teachers have significant demands placed on them for work hours outside the classroom.

Participating teachers also noted a decrease in the amount of time junior high schools devote to language arts, along with a lack of specialized training to deal with developmentally delayed students and their writing. Instructors also face an increase in the number of requirements in the curriculum that have in turn reduced the time for writing instruction. A new speech component has been added to the high school curriculum, to meet the mandates of the California Content Standards document, and that requirement also cuts into time for writing. A wide range of skill levels in any given class, along with limited staff development planning and utilization and a lack of print literacy as a lifestyle for students, were all identified as impediments.

With all of these difficulties, teachers still assign and respond to quite a lot of writing. Honors seniors write nine essays a semester at one school. Freshmen write four essays per semester, with the number of essays varying for each level. District and state standards require that students write narrative, descriptive, expository, and persuasive essays, which include autobiographical incident, biographical incident, 
comparison/contrast, cause and effect, division analysis, process analysis, and example. Teachers thus noted the extraordinary curricular demands to organically integrate these genres into the school year.

Perhaps most interesting to us were the activities that high school teachers identified as being potentially beneficial and appropriate for our project. They requested presentations of college-level expectations for writing, more information about the content of the Developmental Writing course at Cal State Fullerton, statistics on how their seniors do on the EPT, more information about what kinds of questions are asked on the English Placement Test, and samples of prompts and syllabi. Nearly all indicated a desire to continue meeting together at symposia in which high school and university professionals could discuss issues of articulation to college for an increasingly complex student community. With a large population of working class students holding 20 - to 40-hour a week jobs and with a large percentage of the students coming from homes in which English is not their first language, the student community that both the university and high school instructors confront continues to create some interesting challenges. As we discussed these issues, we all agreed that working together to understand those challenges is something we should have done long ago.

The types of support that teachers determined would be most appropriate in working with them in the classroom range from in-class workshops for college prep students on timed impromptu writing tests to teacher workshops that include instruction on what the EPT consists of, its rating systems, and its criteria for success on the placement instruments. They indicated that students need more practice and feedback for the timed impromptu essay, along with strategies for time management and composing in a timed writing situation. Developing a common language to discuss writing and a greater ease with a timed writing situation were also high on the list.

For both of us as co-coordinators of the project, what mattered most was the level of investment that a needs assessment engendered among our high school colleagues. By asking them to identify the issues that we need to deal with together, along with what they see as appropriate site-specific strategies for supporting them with their writing instruction, we were able to elicit a plan that we could come back to. Since the administration of the questionnaire, we have proposed a teacher-researcher collaboration between university and high school participants. Through the teacher-researcher project, we will work with teachers to identify authentic research questions and appropriate research methodologies for studying and evaluating our collective efforts to improve students' writing. By generating research methods suitable to the rhythms of their teaching and writing and by meeting together to share our findings from the various classroom research projects we have launched, we hope to build on the dialogue that will 
enable all of us to study the classroom context together, designing action research agendas that enable teachers to own the research process in ways that a top-down research agenda disallows (Bisplinghoff; Ray). What is most essential is that our high school colleagues experience their participation in this project as fellow professionals, fully capable of determining what strategies and interventions will work for them. Regardless of what changes we make collectively in the project plan, we know that their participation will help to shape a project that we hope makes a difference for them and their students.

\section{Coda}

Looking historically at the CSU's attempts to grapple with what it views as the "problem" of remediation, we see that the solutions proposed during each cycle of concern have rarely varied. The major impetus toward real change in the number of students requiring remediation, working at increasing literacy skills throughout the entire educational system in California, has come about because at the moment, at least, the state is in the best financial situation it has enjoyed for several decades, even as its ranking in the nation's schooling systems places it in the lowest $25 \%$ (Baron). Money is available for collaborative projects, and the state finds that it can pay to reduce class size in ninth grade English to twenty students per class, thus enabling teachers to work more effectively in developing literacy skills. Money is also available for tutors from the university to work in the schools in several outreach programs. Teacher education programs are being funded by the state legislature to strengthen their academic content. The Collaborative Academic Preparation Initiatives project we are working on was impossible six or seven years ago when CSU schools had to operate under tight budgetary constraints.

One wonders, however, what this most recent infusion of money will bring. With classes in the high schools from the sophomore to the senior level still averaging 35 to 40 students each, what impact will an occasional tutor or improved teacher training have in the long run? Teachers still struggle with forty to sixty hours of grading per week after assigning a simple two or three page assignment. We must also recognize that the mission of the high schools varies from that of the university. To assume otherwise would be to appropriate the prerogative of the high schools to work within their communities and respond to their needs. 


\section{Notes}

1. These editorials reflect, as well, the push for tougher standards and more testing, two issues that make the news regularly. On September 9, 1999, a Times' editorial stated almost gleefully that if students cannot meet proficiency standard of EO665 by the end of their first year then ". . it's back to community college to finish remedial work." Of course, these students didn't come from a community college which the Times suggests sending them back to. In a November 22, 1999 editorial, the paper-again rather gleefully-noted that "school officials announced that they were kicking out $5 \%$ of last year's freshman class" who did not pass remedial English and/or math courses. Colleges and taxpayers, it said, should not be paying for "earlier educational failures." Here is the get-tough policy that plays so well among those who write about education today and that ignores the reality of poor schools with even poorer funding. It is no wonder, as stated further on in this essay, that the Times is so enamored of the former football star Charles Reed who now sits in the CSU chancellor's office, who is promising reforms.

2. The Master Plan was set up to stem "intersegmental competition" among the public universities and community colleges (MPR, 3). The mission of the University of California was established as offering, for example, professional education through the doctoral degree, while the CSU was to take as its purview "professional education, including teacher education, through the master's degree" (MPR, 11) Community colleges offer vocational as well as academic instruction and "provide remedial instruction for students inadequately prepared for postsecondary education" (MPR, 10).

3. Much of the research cited in the report comes from developmental education studies. Interestingly, although Shaughnessy's Errors and Expectations is listed in the References at the end of the report, no internal citation to her work can be found. Still, the report takes a realistic and reasonable look at remediation.

4. The report's writers base their choice of "remedial" and "remediation" on the work of K. Patricia Cross, who distinguishes the terms in this way:

If the purpose of the program is to overcome academic deficiencies, I would term the program remedial, in the standard dictionary sense in which remediation is concerned with correcting weaknesses. If, however, the purpose of the program is to develop the diverse talents of students, whether academic or not, I would term the program developmental. Its mission is 
to give attention to the fullest possible development of talent and to develop strengths as well as to correct weaknesses (31).

In the 1990s, commissions and members of the BOT who wrote about remediation seemed not to know that Promises to Keep had defined terms and provided an explanation for its choice. The "Report of the Subcommittee on Remedial Education, Executive Summary" (July, 1995) uses developmental and remedial interchangeably, often writing these words as "remedial/developmental." A June 1994 report on underprepared students in fact indicated that the system had no working definition of these words ("API" 3). The term developmental has been used in reports since 1994 to describe students who are non-native speakers of English and have trouble with written communication, although this term has not actually been defined in the reports.

5. The math department at Cal State Fullerton hired a local community college to teach its remedial courses (that is, until the dean of the School of Natural Sciences and Mathematics realized that over $\$ 40,000$ annually was going to the local college instead of to his school), as did other CSU schools. Many CSUs placed the remedial English courses in basic skills departments or hired community college instructors to teach these courses, and paid the teachers lower, community college wages, although others, including CSUF, retained control of its Developmental Writing courses and continue to teach them through the English Department.

6. Many terms which the BOT uses are not well defined. The Committee on Educational Policy uses other terms in its report which are also not well defined, terms like "remedial/developmental," "precollegiate skills," and "basic skills." For example, precollegiate skills is defined in this way: "the term ... means attainment of the understanding and knowledge that enable students to handle the demands of beginning university study" $(1996,3)$. This is a non-definition if ever there was one.

7. Here is a case of business running education the way business runs itself. Under the heading "Implementation" in the 1995 report, the BOT states that the five-year phase-in plan is crucial. "This will enable all students in the 'pipeline' ample time to develop the required skills in English and mathematics" (12). The board believed that five years would be ample time to make the secondary schools aware of the changes in CSU policy and to give the CSU schools time to assist secondary schools in developing "new tools for learning basic skills." The sentiment seems to be that if five years works to change the assembly line for Ford Motor Company, for example, it can certainly work for educational reform. 
8. Thomas Saenz of the Mexican American Legal Defense and Educational Fund notes that " $\mathrm{Cal}$ State is a prime avenue for Latinos to get a bachelor's degree." (Quoted in the Times, Nov. 18, 1999)

9. The debates surrounding statewide standards for schools have been developing apace with state and local efforts, and many valid objections to state-imposed curricula have peen posed, including criticisms involving the wide ranging authority of the state to shape culture (Sizer 73), to determine the sequence of learning, in the sciences, for instance (Nathan 54), to dictate a laundry list of facts and skills (Nash 47) and to require excessive quantities of knowledge, as in Massachusetts' fourthgrade requirement that all students be responsible for world history to A.D. 500 and U.S. history up to 1865 (Nash 46). Others note the propensity of standards to set up the state as a central authority which is then empowered to dictate and require certain ways of knowing and thereby suppress teacher innovation and democratic education (Meier 6; Sizer 73). Still others note the ways in which standardized tests cannot begin to measure the richness of an individual's intelligence, an argument amply supported in Peter Sacks' Standardized Minds: The High Price of America's Testing Culture and What We Can Do to Change It. One of the more useful critiques comes from Bob Chase, president of the National Education Association, an organization representing 2.4 million teachers across the nation. Chase concedes that standards can indeed be effective in promoting student learning, but only if certain conditions are met: "First of all, the standards must reflect the wisdom of parents and classroom teachers. Second, the curricula we teach must be aligned with the new standards. Third, teachers must be provided the professional development they need to incorporate the new standards into their teaching practice. Fourth, we must insist that no single high-stakes test can measure the academic progress of any studentthat multiple indicators must be employed." (41). Chase's criteria receive support from educators in other areas, especially his insistence on multiple indicators of student achievement (CCCC Position on Assessment). What is most striking is his final condition, that of validity in assessment: "It is intellectually and morally dishonest to raise the bar for all students to a level that is currently being reached by only a relatively few" (41), a mindset akin to the character's belief in the film Field of Dreams: "If we set high standards, students will magically achieve" (41-42). All of these criticisms come into play when discussions about alignment of student achievement with statewide standards and college-level expectations begin. 


\section{Works Cited}

Academic Program Improvement Workgroup on Support for Underprepared Students. "Memorandum." June 20, 1994.

Anyon, Jean. "Social Class and the Hidden Curriculum of Work." Journal of Education 162 (1980).

Astin, Alexander W. "Remedial Education and Civic Responsibility."

National Cross Talk. The National Center for Public Policy and Higher Education. Summer 1998.

Ayers, William. "The Standards Fraud." In Will Standards Save Public Education? Deborah Meier. Boston: Beacon Press, 2000: 64-69.

Balz, John. "'Baby-Boom Echo' Is Putting a Strain on Schools, Study Finds." Los Angeles Times. August 20, 1999.

Baron, Christine. "Improving Education Amounts to Pennies a Day." Los Angeles Times. December 1, 1999: B9.

Bisplinghoff, Betty Shockley, ed. Engaging Teachers: Creating Teaching and Researching Relationships. Portsmouth, NH: Heinemann, 1998.

Bizzell, Patricia. "Basic Writing and the Issue of Correctness, or, What to Do with 'Mixed' Forms of Academic Discourse." Journal of Basic Writing 19.1 (Spring 2000): 4-12

Bodell, H. Goals 2000: A National Framework for America's Schools. Arlington, VA: Education Funding Research Council, 1994.

Borrowman, Shane. "The Trinity of Portfolio Placement: Validity, Reliability, and Curriculum Reform." Writing Program Administration 23.1/2 (1999), 7-19.

California Board of Education. K-12 Academic Content Standards for California Public Schools. Available at http://www.cde.ca.gov/board/ Accessed 8 August 2000.

"Cal State Is for College Work." Los Angeles Times. September 12, 1999.

Chase, Bob. "Making a Difference." In Will Standards Save Public Education? Deborah Meier. Boston: Beacon Press, 2000: 40-43.

"College Is for the Prepared." Los Angeles Times. November 22, 1999. College Remediation: What It Is. What It Costs. What's At Stake. The Institute for Higher Education Policy. December 1998.

Collins, Terence and Melissa Blum. "Meanness and Failure: Sanctioning Basic Writers." Journal of Basic Writing 19.1 (Spring 2000): 1321.

Commission for the Review of the Master Plan for Higher Education. The Master Plan Renewed: Unity, Equity, Quality, and Efficiency in California Postsecondary Education July, 1987.

Crowe, Edward. "Statewide Remedial Education Policies: State Strategies that Support Successful Student Transitions from Secondary to Postsecondary Education." Strategy Brief. State Higher Education Executive Officers. September 1998. 
"CSU Guarantees Local Access to Students." Cal State Fullerton Senate Forum. April 17, 2000.

“CSU Plan To Reduce Remedial Activity, 1985 - 1990." California Postsecondary Education Commission. December 1984.

"CSU Remediation Levels Off." CSU Stateline. March 1999: 2-3.

"Executive Order No. 665: Determination of Competence in English and Mathematics." Office of the Chancellor. February 28, 1997.

Fox, Tom. "Basic Writing as Cultural Conflict." In Critical Literacy in Action: Writing Words, Changing Worlds. Eds. Ira Shor and Caroline Pari. Portsmouth, NH: Heinemann, 1999: 68-86.

Gilyard, Keith. "Basic Writing, Cost Effectiveness, and Ideology." Journal of Basic Writing 19.1 (Spring 2000): 36-42).

Gleason, Barbara. "Remediation Phase-Out at CUNY: The 'Equity versus Excellence' Controversy." College Composition and Communication 51.3 (February 2000): 488-491.

Gleason, Barbara. "When the Writing Test Fails: Assessing Assessment at an Urban College." In Writing in Multicultural Settings. Ed. Carol Severino, Juan C. Guerra, and Johnnella E. Butler. New York: Modern Language Association, 1997.

Goals 2000: Reforming Education to Improve Student Achievement. April 30, 1998. Available at http://www.sheeo.org/transitions/ symposium98.html. Accessed July 29, 2000.

Goulet, Denis. Introduction. Education for Critical Consciousness. Paulo Freire. New York: Continuum, 1989.

Haycock, K. "Thinking Differently about School Reform: College and University Leadership for the Big Changes We Need." Change (1996, January/February): 13-18.

Lewiecki-Wilson, Cynthia, and Jeff Sommers. "Professing at the Fault Lines: Composition at Open Admissions Institutions." College Composition and Communication 50.3 (February 1999): 438-462.

Meier, Deborah. Will Standards Save Public Education? Boston: Beacon Press, 2000.

Miller, Susan. "A Future for the Vanishing Present: New Work for Basic Writing." Journal of Basic Writing 19.1 (Spring 2000): 53-68.

Mutnick, Deborah. "The Strategic Value of Basic Writing: An Analysis of the Current Moment." Journal of Basic Writing 19.1 (Spring 2000): 69-83.

Nathan, Linda. "Habits of Mind." In Will Standards Save Public Education? Deborah Meier. Boston: Beacon Press, 2000: 50-56.

Nash, Gary B. "Expert Opinion." In Will Standards Save Public Education? Deborah Meier. Boston: Beacon Press, 2000: 44-49.

"Precollegiate Skills Instruction." CSU Committee on Educational Policy. January 23-24, 1996.

Promises To Keep: Remedial Education in California's Public Colleges and Universities. California Postsecondary Education Commission. 
January 1983.

Ray, Ruth E. The Practice of Theory: Teacher Research in Composition. Urbana, IL: National Council of Teachers of English, 1993.

"Report of Subcommittee on Remedial Education." Board of Trustees, California State University. Committee on Educational Policy. July 18-19, 1995.

"Report of the API Faculty Workgroup on Support for Underprepared Students." June 10, 1994.

Rodby, Judith and Tom Fox. "Basic Work and Material Acts: The Ironies, Discrepancies, and Disjunctures of Basic Writing and Mainstreaming." Journal of Basic Writing 19.1 (Spring 2000): 84-99.

Sacks, Peter. Standardized Minds: The High Price of America's Testing Culture and What We Can Do to Change It. Cambridge, MA: Perseus, 1999.

Sarhaddi Nelson, Soraya and Richard O'Reilly. "Minorities Become Majority in State, Census Officials Say." Los Angeles Times. August 30, 2000.

Shaughnessy, Mina. Errors and Expectations. New York: Oxford UP, 1977.

Shor, Ira. "Illegal Literacy." Journal of Basic Writing 19.1 (Spring 2000): $100-112$.

Shor, Ira. "Our Apartheid: Writing Instruction and Inequality." Journal of Basic Writing 16.1 (Spring 1997): 91-104.

Singer, Marti. "Moving the Margins." Mainstreaming Basic Writers: Politics and Pedagogies of Access. Gerri McNenny, ed. Mahwah, NJ: Lawrence Erlbaum, forthcoming.

Sizer, Theodore. "A Sense of Place." In Will Standards Save Public Education? Deborah Meier. Boston: Beacon Press, 2000: 70-80.

Soliday, Mary. “Class Dismissed.” College English 61 (1999):.

- - - "From the Margins to the Mainstream: Reconceiving Remediation." College Composition and Communication 47 (1996): 85100.

- - . "Ideologies of Access and the Politics of Agency." Mainstreaming Basic Writers: Politics and Pedagogies of Access. Gerri McNenny, ed. Mahwah, NJ: Lawrence Erlbaum Press, Forthcoming.

Sommers, Jeffrey, Laurel Black, Donald A. Daiker, and Gail Stygall. "The Challenge of Rating Portfolios: What WPAs Can Expect." Writing Program Administration 17.1-2 (1993): 7-29.

State Higher Education Executive Officers (SHEEO). "State Strategies that Support Successful Student Transitions from Secondary to Postsecondary Education: Symposium and Briefing." Available at http://www.sheeo.org/tranistions/symosium98.html Accessed 9 August 2000. 
Spence, David. Letter Sent to Presidents. Request for Proposals to Implement CSU-High School Collaborative Academic Preparation Initiatives. 3 Sept. 1999.

"Statement on Competencies in English and Mathematics Expected of Entering Freshmen." The Academic Senates of the California community Colleges, The California State University, and the University of California. November 1982.

Troyka, Lynn Quitman. "How We Have Failed the Basic Writing Enterprise." Journal of Basic Writing 19.1 (Spring 2000): 113-123.

Wiener, Harvey. "The Attack on Basic Writing-And After." Journal of Basic Writing 17.1 (Spring 1998): 96-103.

Yancey, Kathleen Blake and Irwin Weiser. Situating Portfolios: Four Perspectives. Logan, UT: Utah State UP, 1997. 


\section{Joan L. Piorkowski and Erika Scheurer}

\section{"IT'S THE WAY THAT THEY TALK TO YOU": INCREASING AGENCY IN BASIC WRITERS THROUGH A SOCIAL CONTEXT OF CARE}

ABSTRACT: As basic writing teachers, our goal is to help students to take on the role of responsible writers. Part of taking on this role involves students' using available resources in ways that enhance their development. This essay explores a question that troubled us as basic writing teachers: in a program that is heavily supported, why did relatively few students seek out and use those resources? Under what circumstances do students seek and not seek help with their writing? Our research revealed that while various factors influence students' decisions to use resources, one factor stands out: the perception of a context of care in the basic writing classroom. Students 'perception of a context of care is crucial to their taking on the role of responsible writer.

Interviewer: "Would you go to the teachers or tutors for help if it was not required?"

Carl: "Probably not, unless. . I think there was one time when I went when I wasn't required to, but that's just me. I mean, I can't speak for everyone. I think a lot of people seek out help without being told to. I'm just kind of independent..."

Interviewer: ". . . in what kind of situations do you normally ask for help?"

Carl: "... I guess this goes back to my independent thing. I don't really ask for help a lot, I just kind of deal with it myself. No matter what kind of pain it causes me, I don't ask I guess, I just deal with it myself."

As writing teachers, we are familiar with students like Carl, students who cherish their independence and resist using outside resources such as teachers, students or peers as they write. This resis-

Joan L. Piorkowski, Professor of English at the University of St. Thomas, has been teaching basic writing for over twenty years. She established and directed the university's Writing Center and Academic Development Program. Erika Scheurer, Associate Professor of English at the University of St. Thomas, has been teaching basic writing for eight years. She restructured and currently directs the Academic Development Program. 
tance to seeking help is especially troubling to us as basic writing teachers; we know that students must develop a social view of the writing process in order to become confident, responsible writers. What leads students to take a social view of the writing process, to solicit feedback actively from others? Through our study we have found that to our students, a crucial factor is a perception that the person they are seeking feedback from cares about them and their writing.

We teach in a well-funded, fully supported program, the Academic Development Program, at the University of St. Thomas in St. Paul, Minnesota. Our class size is limited to fifteen students, and each section is assigned an undergraduate student TA who facilitates intensive one-on-one work. Indeed, the course's level of challenge led us to change the name from "Basic Writing" to "Intensive Writing." Students have access to the university's Writing Center and to personalized academic counseling. Adhering to the common knowledge in our field, that any successful writing program targeted to underprepared students include a range of support services, we designed our course so that the sixty students who participate in it each year have access to the kinds of support that will enable them to assume responsibility for their own writing, preparing them to succeed in a university setting. ${ }^{1}$ Unlike our colleagues in other institutions who recount nightmare tales of administrative underfunding, poor facilities, and overcrowded classrooms, we are confident that the circumstances for teaching and learning are virtually ideal.

Yet we questioned our certainty in the Fall of 1993 when we noticed with increasing concern that not all students used the full range of resources available to them. While virtually every student worked with the instructors one-on-one (usually because we require conferences), significantly fewer followed up with one-on-one work with the student assistants, and even fewer used the Writing Center or other resources. Why? Was it a question of time management? Of low motivation? Was it possible that the conventional wisdom of the field did not apply in our circumstances? In order to find out why, in Fall 1994, we extensively surveyed all four Intensive Writing sections and conducted follow-up interviews in Spring, 1995. ${ }^{2}$

In the course of our research, we identified three variables that appeared to affect students' likelihood of getting help with their writing. The first two did not surprise us: first, students who held a collaborative view of the writing process sought help while those who held an individualistic view did not, and second, students who anticipated a negative, even shaming, response to their work did not seek help. There is considerable literature in the field of basic writing documenting the effect of negative feedback on student writers and the limitations that a rule-driven, non-collaborative view of process places on writers. ${ }^{3}$

What did surprise us were remarks which identified a third vari- 
able, the importance of the affective domain in students' willingness to seek help with their writing. Ted, for example, describes the connection between his perception of the teacher's care and his own motivation: "It was like, the teachers, to me, it didn't seem like they cared. So, I didn't care. But you know, like in college, the teachers. . . that I've had so far, they seem like they care. I wanna go get help from them." Student after student echoed Ted's sentiments. They stressed how knowing that those responding to their writing cared about them helped them, both in their motivation to write and in their motivation to seek help with their writing. In our research, we wanted to understand more fully how students describe and experience the caring relationship which they define as crucial to their willingness to seek help.

Searching the field for scholarship on the role of affect in writing led to a short, but useful list of sources. ${ }^{4}$ Rhonda Grego and Nancy Thompson assert the importance of attention to students' psychic needs in the teaching of writing. They provide a persuasive theory regarding the larger profession's lack of recognition of the significant work that writing teachers do in this area: while "[I]t is easy for the institution to sanction the work we do in helping students standardize their writing for the academy. . . the academic institution finds it very uneasy to sanction, to intellectually admit the bulk of the personal and interpersonal work that compositionists also do with students" (64). We agree and suspect that this lack of institutional recognition relates to the lack of research in the area of affect and writing.

This state of neglect is beginning to change, however. Recently, Susan H. McLeod, in Notes on the Heart: Affective Issues in the Writing Classroom, has produced the most comprehensive discussion of the complex role of affect in composition. Grounding her work in her classroom experience as well as in both cognitive and social theories of composition, psychology, and sociology, McLeod presents numerous ways that writing teachers may draw on contemporary understandings of the affective domain in order to reach students more effectively. In her third chapter, "Motivation and Writing," McLeod points to the importance of students' perceiving control over writing situations; of their goals being focused on learning rather than on performance; and of their view of intelligence being incremental, not a stable entity. She introduces two sets of terms which have helped us reconsider the connection of care and student motivation. First, a student who sees learning as "incremental" is oriented towards learning something new, whereas one who sees intelligence as a "stable entity" is oriented to being judged by others as smart (57-58). McLeod's second set draws on the work of Richard deCharms and explains the link between students' motivation and their engaging in either "origin" or "pawn" behavior. "Origins" feel they have control over their behavior and thus "take personal responsibility for their actions, for their learning" 
(49). Pawns, however, "see their behavior as determined by external forces beyond their control" and thus do not take responsibility (49). These sets of terms have been particularly useful to us as we have explored the connection of students' perceptions of care and their motivation to seek help with their writing, to take responsibility for their work. McLeod's work helps us to understand the complexity of the affective domain in the teaching of writing. As we work to understand that complexity, we must be cognizant of the assumptions about writing and learning that students bring to the class.

With our attention now focused on the role of affect in students' attitudes towards writing, in particular on the link between care and student agency, we together re-interviewed the six students in our original study who were still attending St. Thomas a year after our first interviews. We invited the students to respond to the transcripts of their first interviews and our interpretations of their comments. ${ }^{5}$ Student responses clarified further how important the affective domain was in their assuming responsibility for their writing by seeking help. They also convinced us that students' perception of a context of care in the classroom is a crucial factor in building their confidence as writers and is inextricably linked to their assuming agency and responsibility for their own progress as writers.

Before we proceed with our case studies, we would like to define three key terms. By "agency" we mean a personal sense of empowerment, a sense of being the subject, not the object of action. "Responsibility" results from recognizing one's own agency, implying not only empowerment, but also a sense of accountability. Student writers, then, who recognize their own agency would see themselves as responsible for deciding what activities, such as using support services, fostered their own development as writers. ${ }^{6}$ Our understanding of the term "care" is informed by the work of feminist philosopher Nel Noddings, who defines a reciprocal "ethic of care" based on the complete receptivity of both the care-giving teacher and the cared-for student. ${ }^{7}$ According to Noddings, in a caring relationship, both the one-caring and the one-cared-for must be "receptive" to one another (30). The onecaring demonstrates her "engrossment" (17) or complete receptivity to the one-cared-for by her confirmation and support of his goals. This open and non-judgmental state is the essence of the caring relationship: "To the cared-for no act in his behalf is quite as important or influential as the attitude of the one-caring" (19-20). The one-cared-for confirms his corresponding receptivity by his response which need not be "gratitude or even ... direct acknowledgment" but a "free, vigorous, and happy immersion in his own projects (toward which the one-caring has directed her own energy also)" (181). We would like to emphasize that when we discuss care it is not as an absolute terme.g., that a teacher is either caring or not caring - but rather as a term 
relative to the student's perception. One student may perceive a teacher as caring and another as not.

A perception of a context of care is important to the nine students we interviewed. Although not everyone uses the word "care," the interviews are rich with descriptions of caring (and not caring) teacherstudent relationships. Kerri, for example, stresses the importance of a non-judgmental attitude on the part of a teacher or tutor. Identified by her instructor as a student who frequently seeks feedback and makes use of resources, Kerri describes how her attitude toward the Writing Center changed when she realized she was not going to be belittled:

I didn't know what they would think of me. I didn't know if they would look at my work and go "Oh my god, she really doesn't know how to write a paper." But now it's no big deal because I've seen some other people down there seeking help and they're not down there to judge you; they're just down there to give you feedback and I think I had it set in my mind that they were just going to judge you and laugh at the door after you leave.

Once she is convinced that "they're not down there to judge you" she is willing to use the resource. Note that Kerri's is not simply a fear of negative feedback (expressed by many of our interviewees); it extends to a fear of her character being judged based on her writing. A nonjudgmental attitude, even while offering a critique of a student's work, fits with Noddings' ethic of care.

The students also describe many instances of routine, brief, teacher-student interaction as caring encounters that spur their motivation. They cite, for example, the tone of their teachers' written and oral feedback, teachers' attempts to draw shy students into discussions in non-threatening ways, and, in one case, a teacher calling a student who has missed class to find out if she is okay. One student, Jim, vividly recalls a single remark:

I remember distinctively [the instructor] saying "You're really on the ball on this book, [Jim], and I'm glad you're on the ball. You know what you're talking about." And that just drove me to read the whole book and write a good paper... You don't have to go on for days praising somebody. Just to say that was good, just a few words, it made me think that wow, at least she's noticing that and it's not a lost cause.

Comments like Jim's reveal that teacher demonstrations of care need not be elaborate or extended to be effective. Small comments and gestures clearly have a powerful effect in transmitting the attitude of care 
that Noddings defines as central to the caring relationship.

Ted, one student who explicitly mentions care in both interviews, highlights his teacher's affect of accessibility when asked to describe how he knew a teacher cared about him:

It's the way that they talk to you ... It's a kinda way that I feel, like I would be able to always talk to them ... It's like a bond. Cause she ... was there to help me whenever I needed it. So now I feel whenever I need help that I can go back to her. Or go back to one of my teachers that helped me. [It's] being available, and letting me know that, if you need help, I'll be there to help you.

Ted's perception of his teacher's accessibility emphasizes that caring is mutual and plays an important role in his willingness to ask for help.

Though the experiences and perceptions of each of the students we interviewed are complex and unique, several conclusions have become clear to us: (1) students feel that they can readily identify an attitude of care; as one noted, "you can tell the people that really care"; (2) by a caring attitude, they do not mean an extended intervention, but rather the teacher's day-to-day receptivity punctuated by occasional intense engrossment in their concerns (3) students are more willing to seek out help with their writing and take on the role of responsible writer when they perceive a context of care.

Now we would like to turn to two case studies, Max and Kathy, to demonstrate how a perception of a context of care can inform a student's willingness to take on the role of responsible writer.

\section{Max: "Yes, you can write if you want to."}

In his first interview with us, Max describes the lack of personal agency he felt as a writer in high school. He revised little, if at all, and his goal was merely to complete the assignment. How much work he put into a piece of writing depended solely on how much the grade counted. Because he perceived a context of care in his first year college writing classes, however, Max shifted in the course of two semesters to a position of responsible agency. From our interviews with him, we noted that two elements in this context of care are particularly important: (1) writing for a purpose-his own, not someone else's - and (2) open-minded, supportive readers.

If we looked at Max's writing alone, it is likely that we would label him as a student who made minimal progress in his first year at the university. In each of the three writing profiles he completed, he describes himself as a struggling writer. In the first profile, he writes, "I feel that it [writing] is difficult because I get confused with all the 
writing symbols and ideas and the things to make a good paper." In the second profile, he identifies his "wordy expression and lack of depthness" as the reason for this difficulty. And in the final profile, he notes, "Writing is still difficult to me because I like to get ahead of myself and still have problems keeping ideas clear."

Despite this continual struggle with writing, Max makes tremendous progress as a writer, changing from a student who writes with the sole aim of getting papers finished to a teacher's satisfaction, to a student who writes to learn about himself and the material he is studying. The change in Max's attitude towards writing is evident in his survey answers to the question asking whether he likes to write. In his first response he says, "I like to write somewhat, only when it doesn't depend on a grade because I feel pressure on myself when the writing is graded." In his end-of-semester response, he notes, "I like to write because it's a way I can express my viewpoints and my ideas and it lets me understand my purpose." Max comes to take responsibility for his writing and learning, to feel a sense of agency and embrace the role of a writer; as a result, he fully utilizes the resources available to him: teachers, peers, and tutors.

Being encouraged to write for his own purposes, not the teacher's, is the first sign of care leading Max to increased agency. Max links his increased sense of responsibility as a writer to the kind of writing he is asked to do in college: "It's not what the book says or anything, it's more of what we think." Max's perception of control leads him to develop a sense of personal agency and responsibility, what McLeod calls "origin" behaviors. He notes that this sense of purpose "makes it more interesting to write as well as to read." Instead of simply reporting information or the teacher's opinions, Max becomes engaged with the process of trying to figure out and develop his own opinions on the subject matter.

Max elaborates on this shift to writing for his own purposes in both of his interviews. In high school, he says, he wrote simply to get the assignment done, usually at the last minute. He didn't engage with the subject matter, "I just kind of stayed up on top. You knowI really didn't get into the stuff." Max concludes, "You could either learn it or you could write it, or you could do both. And I just wrote it, you know. My purpose was just to write it ... the purpose became both now [in college] - to learn and to write." By learning, Max seems to mean not only writing-to-discover, but also the more fundamental idea of a writer actually understanding what he has written. He says his writing class "gave us a challenge to write. But the challenge, I think, was mostly to understand what we're writing about. And that's a big thing that I learned, to understand what I'm writing about."

Max describes himself as "on the verge of being an active writer." When asked in the follow-up interview what he means by "active," he 
notes that understanding what you are writing and being clear are only a part of what it means to write: "the understanding and clear part comes from what you do beforehand ... what I mean by active is like making sure I'm doing the right things ... I'm doing more steps in order to better my writing."

Connected to this internalized sense of purpose, the second major step that Max adds as he has become a more active, responsible writer is to solicit feedback from others as he revises. Although he still prefers to work alone on his writing, his attitude towards collaboration with others changes drastically in his first year. This changed attitude towards getting help - whether it is from the instructor, from student assistants, Writing Center tutors, or friends - was directly connected to the kind of help he received. In his interviews he stressed the importance of finding the right people: "I mean, if you find a person with an open mind, an open-minded person, then it's gonna be for the better." In his second interview he explained further that an openminded person "would see both sides of the issue ... so you can support what you're saying." The person, then, does not try to force Max to adjust to her agenda, but uses her knowledge of different viewpoints to help him to support his point.

Max also stresses the importance of supportive feedback, not simply criticism: "You don't need someone there, like, breathing down your neck saying no, this isn't right. I think you need more support than you do criticism." He doesn't discount criticism - "the negative is there just to keep you on track" - but notes:

People with writing problems ...they don't need to like look at all the red marks because they already know that they're gonna be coming...I think that's what leads a lot of people away from writing ... A teacher can just hand it back with, "Well, you gotta work on it." Well he knows that. He knew he had to work on it.

Like many of the students we interviewed, Max emphasizes that what he means by support is far from elaborate or time-consuming. He mentions little things such as the teacher giving him a word of positive reinforcement: "I've never really been a good writer and I've always kinda struggled with it. So someone like me, I just kinda look for, you know, any little thing that's gonna help me. Like if the teacher says you're on the right track."

Max's perceptions of support and control cause him to take on the role of a responsible writer. On one level, his development is a direct result of the student-centered workshop pedagogy that Brooke and others advocate. He has come to see writing as a social process through which he learns and communicates to others for a purpose, 
his purpose. Part of that process involves soliciting the feedback of others - not for "the right answer," but for discussion that will lead him to achieve his goals as a writer. Indeed, our final interview with Max a semester before he graduated included the following exchange:

Interviewer: "Would you say overall that you've been successful as a writer in terms of doing well on papers? Do you generally get decent grades for your writing?"

Max: "I think that I've done well the past few years, yes. I don't think that I would judge how well I've done writing on my grades that I get ... I think I would just judge the increased learning in writing."

Unlike his depiction of himself in high school, Max has become what McLeod calls an "incremental theorist," focusing on the learning process more than the product, the grade. Or as Brooke would say, he has moved from playing the role of student to adopting the role of an active, responsible writer.

We view Max's transformation from the role of student to the role of responsible writer as a response to the care he perceived in his first year at the university. Although Max never mentions the word "care" on his own in either interview, his accounts of writing for his own purposes, the open-minded reader and positive, helpful feedback fit exactly Noddings' description of the relationship between the onecaring and the one cared-for. When Max's teacher (the one-caring) displays an attitude of openness and support for his goals, Max (the caredfor) reciprocates by what Noddings characterizes as a "free, vigorous, and happy immersion" (181) in his own writing and his role as writer.

Max reinforced our interpretation at the end of the second interview when he asked us to describe our findings. When we mentioned how some other students had indicated the importance of care, Max agreed,

I guess that's a big thing too. I guess I really didn't look at it that way. How people care, that's a positive thing itself. They say, "Yes, you can write if you want to." You know, people are looking for that.

$$
* * *
$$

Kathy: "I guess English isn't my subject"

Kathy was identified by her Intensive Writing teacher as a student who did not seek help on her writing. In her first interview she confirms this perception, noting, "I'm just not the type to go and ask for help. I know I should, but I'm stubborn"; a year later, her attitude 
remains the same. Why is Kathy so resistant to using the resources available to her?

Unlike Max, Kathy does not identify herself as a successful writer over the course of her first-year writing classes, never taking on the role of responsible writer. At the time of our second interview, she remains both confused about and resistant to the role of a college writer with its emphasis on process. She continues to be very teacher-and grade-focused, seeing herself as what McLeod calls a "pawn" in a situation over which she has little control. Kathy clearly demonstrates an "entity" theory of intelligence, focusing on outcomes, particularly grades, and not on learning as a process.

In her first survey, completed at the beginning of her Intensive Writing class, Kathy ranks herself as a confident writer (4 out of 5); however, she expresses uncertainty and inadequacy about her ability as a writer: "I'm not really sure if I will improve or not. Writing is my main problem. I never really did well on my high school papers." By mid-semester her confidence has plummeted enough to drop to 1 , the lowest possible score, "because I haven't received a good grade in my class at all." She links her negative attitude towards writing directly to her grade: "I don't like to write because the grade shows what is wrong with the paper. If I get a bad grade my self-esteem goes lower and I feel like I can't write at all."

Kathy's direct connection between her "bad grade" and her lack of self-esteem identifies her as highly dependent on external sources (the grade) for her motivation, and sets her up to be frustrated and to evade responsibility for learning to write (because of the bad grade she "can't write at all"). Kathy's focus on grades as an exclusive determiner of her success is all the more remarkable given that it occurred within the context of a portfolio evaluation system in which she could revise until the end of the semester. In her final survey, she remains grade-driven, ranking her confidence at 2: "when writing is difficult for someone it isn't much fun to get papers back with bad grades." She admits defeat in achieving the course's goals, noting "my writing has gotten progressively worse." One reason, then, for Kathy's resistance to utilizing outside resources in her writing is that throughout her first semester of college, she never identifies with the role of the writer. She continues to see herself as a pawn in a system where writing is a test to be graded and a process where the teacher is active but she is clearly passive.

One change that did occur by the end of Kathy's first semester, however, is in her attitude towards working with peers. Whereas at the beginning of the semester she prefers to work alone, by its end she recognizes the validity of peer feedback in which one gets comments that are "helpful for revising to make the paper all it can be."

In our interviews, we asked Kathy to elaborate on her use of peers 
as resources. ${ }^{8}$ We discovered that Kathy is most comfortable when the person giving her help in any context (e.g., writing class or sports) knows her. Yet, unlike Max's open-minded reader, Kathy's ideal caregiver shows her support by being directive about how exactly she should revise her paper. She believes that she is more likely to get this kind of help from peers she knows, whom she perceives as caring about her: "If you know the person and the person knows you, that they'll give you more true of an answer, 'cause they'll know how you react. Rather than the people that don't know you don't know how you'll react and they won't give you the full picture." She is suspicious of people who don't know her, like Writing Center tutors, who "might not give you what you wanted, what you need." When questioned about the kind of feedback she received from friends, she notes that she got feedback on "everything," from style to structure, and that the feedback was both supportive and direct about needed changes.

For Kathy, asking for help from teachers is more problematic. She perceives her college teachers as wanting her to write what they want, not want she wants. This experience contrasts with her memories of high school: "the teachers were kind of, more helpful. They were like, 'okay, just write what you feel is good, and then we'll go from there.'" The lack of control she perceives about her writing leads her to be frustrated in conferences with her teachers, where she expects help but does not get it: "they answer the question but not in the way I need them to answer it. They don't go into depth." On the one hand, Kathy wants the freedom to write what she wants (this is the situation in high school which made her feel confident), but on the other hand, when she seeks help, from either peers or teachers, she wants an exact answer: "If I need the help then I need the help in a serious way, that's all." Unlike Max, who perceives open-ended responses as invitations, Kathy perceives them as evidence of the teacher's lack of care: "You go in there and you ask for the help and they never give you the answer... or they give it in a roundabout way like they don't have the time." In short, as an entity theorist, she believes that teachers have the answer but that "they don't give you the answer" and this perception reinforces her passive, "pawn"-like view of herself as a writer: "I sit there and then, after I leave, I say huh? what am I supposed to do now?" Thus, Kathy avoids instructors, preferring to solicit feedback from friends who, in her perception, know her and care enough about her to be directive.

On one level, we might describe her dilemma as epistemological in nature. She seems caught between a relativistic view that writing and knowledge are all personal expression and therefore not subject to judgment (except, perhaps, in the area of proofreading, which seems to be what her friends helped her with the most) and a more dualistic paradigm in which writing is a puzzle to which there is an absolutely 
correct answer known by the teacher. As Chris M. Anson, citing William Perry's stages, observes in his study of response styles, "As writers, students just making the transition into the multiplicity of relativism [from dualism] often believe that the teacher knows the 'correct' way to write an essay but is craftily withholding this wisdom for the sake of pedagogy" (335). From a developmental perspective, then, Kathy's resistance to taking on responsibility as a writer is connected to her position between two stages.

A developmental explanation does not fully account for Kathy's concerns, however. What was most crucial to her was more intangible; "It's totally the attitude aspect," she says, and that attitude must demonstrate care. She expresses willingness to connect with her teachers, but the teacher has to make the first move, "if the teacher is willing to get to know me, then I'm willing to get to know that person." When asked how a teacher could demonstrate care, she explains care as the teacher's personal attention to the needs of an individual student: "they don't just call on you because you're not talking in class . . but also they actually take time to help you during the class to make you talk." For Kathy the teacher's actual behavior is not as important as her perception of the teacher's caring attitude toward her. Kathy clearly recognizes a context of care in the classroom when her teachers talk to her "on a friendly basis ... not just as teacher but as a person."

No matter how caring Kathy's teachers may have been (her first semester teacher was characterized by other interviewees as extremely caring), her belief that her teachers' indirection was a case of withholding "correct" answers caused her to perceive them as not caring. Also, given the connection of Kathy's self esteem to grades, the teacher's role as a judge reinforces this perception. Since she perceives her environment as uncaring, Kathy rarely solicits feedback from her teachers and does not take on the role of an active writer. At the middle of her sophomore year Kathy remains frustrated: "I guess English isn't my subject," she concludes.

\section{Conclusion}

In reviewing our case studies of Max and Kathy, we can see that, despite their differences, they do agree in three areas. Both are dismissive of teachers who fill papers with red marks, disregarding students' ideas. Both identify a caring teacher as one who takes a personal interest in the student's success - as Kathy notes, "not just as teacher but as a person." Finally, in their first year of college, both Max and Kathy become more willing to solicit and value feedback from peers on their writing. Their understanding of the purpose of feedback, however, could not be more distinct, a direct result of their dif- 
fering perceptions of care in their writing classes.

Though at the beginning of the course, Kathy ranked her confidence as a writer more highly than did Max, by the end of their first year, he is clearly the more confident writer with a developing sense of agency. He perceives himself as an active agent, in control of his writing processes and purposes (McLeod's "incremental theorist," who displays an "origin" attitude). When he solicits feedback, his aim is not only to improve the specific piece of writing he is working on, but also to improve as a writer. While Max is concerned with learning, Kathy is concerned with performance. She, unlike Max, sees writing ability as a fixed entity and engages in "pawn" behavior; she perceives herself as having less control over her writing as the year progresses, focusing almost entirely on grades as a means of measuring success. When she does solicit feedback, she wants either complete affirmation or to be told, in a directive way, exactly what to change.

Our research reveals that when students perceive a context of care in the basic writing classroom, they are more likely to take on "responsible" attitudes and behaviors - such as valuing and seeking out feedback from others on their writing. This context of care is a complex, dynamic and mutual relationship between the student and the person giving feedback. It would be easy simply to label Max as a "mature" and "responsible" writer and Kathy as "immature" and "irresponsible," but that would be unfair to them both. For Max, a context of care is present when he perceives control over his purpose in writing, receives open-minded, non-judgmental feedback and small expressions of acknowledgment and support. He responds to this perception of care by taking on the role of responsible writer. For Kathy, on the other hand, these forms of care do not register since she focuses almost exclusively on her grades. She perceives herself as not being listened to ("I want to write what I want to write"), and as a result shuts down. She remains paralyzed, fixed on writing for grades, unable to perceive and enter the caring relationship.

How do we create a context of care in our classrooms, knowing that some students may perceive that care differently than we intend? What can we as basic writing teachers do to reach the Kathys in our courses - students whose assumptions about writing and learning lead them to take a passive role in their education-especially since they tend to outnumber students such as Max? How can we invite them to engage with their teachers, peers and their own ideas in the serious way that promotes their becoming active writers, writers who will seek out and utilize resources?

In the semesters since we began our study, we as teachers have found it helpful to think more about the relational part of teacher-student interaction as defined by Noddings; to explore more fully how our classrooms function as contexts for caring relationships; and to 
reflect on how our students are perceiving our attempts at demonstrating care. As our respondents told us repeatedly, our demonstrations of care do not have to be elaborate or time-consuming, but they do need to be consistent and positive. We and our teaching assistants are more consciously employing strategies - casual, informal conversation before class, for example-which students perceive as caring and which demonstrate to them that we recognize them as individuals. We look for ways to give students more choice and control over how the class is structured, how writing topics are determined, and how their writing is evaluated. We continue to use pedagogical approaches such as portfolio evaluation which de-emphasize our role as judge, a role that interferes with students' ability to perceive a context of care and assume responsibility for their writing.

But most importantly, we have become more explicit about expressing care. As we learned from Kathy, we can't assume that a student perceives the care we think we are demonstrating. We find ourselves frequently using phrases such as these: "It matters to me that you understand this," "I know getting a good grade is important to you," "It's helpful to me to understand what's confusing you," and "I'm suggesting this because I care about you." When we encourage students to seek outside resources such as the Writing Center, we stress to them that the staff they will encounter in these settings care about them and their writing. All of these strategies invite our students, through dialogue and collaboration, into caring relationships

We tend to think of student responsibility as a freestanding entity, as something over which we as teachers have no control. It's true: you can't make someone be responsible, to feel a sense of agency, or take on the role of writer. But what we're learning from our students suggests that responsibility does come in response-in response to a surrounding context which includes care.

\section{Notes}

We would like to thank the following persons for their help and support with this project: Susan Callaway, Carrie Miller, Robert K. Miller, Dana Simonson and all the students from the Intensive Writing classes of Fall 1994 who participated in the survey and follow-up interviews. Also, we thank the University of St. Thomas for the Research Assistant Grant that was crucial to our completing this project.

1. According to "Standards for Basic Skills Writing Programs" (1979),
in an effective program "Teachers and students have access to and
make regular use of a wide range of resources (e.g., library services,
media, teaching materials, duplicating facilities, supplies) for support 
of the writing program" (222). Today, this range of resources would also include access to one-on-one tutoring such as that available in writing centers.

2. We surveyed students at the beginning of the semester, at the midpoint, and at the end. In the survey we asked students about their writing processes, their attitudes towards writing, and their attitudes towards getting help on their writing (see Appendix 1). Based on the surveys and on classroom experiences recorded in our teaching journals, we chose nine students to interview in early Spring, 1995 (see Appendix 2 for interview questions). In cooperation with their instructors, we had identified these students as either extremely likely or extremely unlikely to seek help with their writing.

\section{See, among others, Shaughnessy, Bartholomae, Rose, and Troyka.}

4. Mike Rose's work, especially Lives on the Boundary, provides a groundbreaking first-hand account of the cognitive and emotional effects of being labeled "remedial." Lad Tobin, in Writing Relationships explores the role of the interpersonal in the writing class. Other scholars not only demonstrate the importance of affect and the interpersonal in teaching writing, but argue that it be given a legitimate space in the field of composition. Alice Brand notes the neglect of emotion as a significant variable in contemporary (often social constructivist) writing theory, arguing "Emotional processes are not hostile to cognitive or social ones. They are profoundly complementary" (402).

5. We would like to identify three measures we took to increase the "triangulation" and accuracy of our study. First, in 1994-1995 two undergraduate Research Assistants-Dana Simonson and Carrie Miller-collated the surveys, helped interview the students, transcribed the interview tapes, and (most importantly) participated in the interpretation of our data. Dana has gone on to present two papers based on our research at national undergraduate conferences. Second, to create some distance from our student subjects, in our initial interviews, we did not interview our own students. Finally, as noted, for those students we had the opportunity to interview a second time, we provided a transcript of the first interview for the students to correct and clarify.

Despite these measures, we recognize that what we are presenting are our naturally limited readings of complex cognitive and affective phenomena. We agree with Anne J. Herrington that "unless participants participate as equals in writing the account of a study, the 'researcher'... is still the central one to construct the knowledge" (51). Since this ideal of student-participants co-authoring texts is not always 
possible, Herrington stresses the importance of researchers' "self-reflection and open-minded dialogue and questioning with others" (65). We have attempted to conduct our research in this spirit.

6. As the work of Robert Brooke illustrates, taking responsibility is central to students' development as writers. Using identity negotiations theory, Brooke explores how students come to take on the role of the writer rather than the role of the student in college writing classes. Whereas the role of the student allows the teacher to direct the learning, the role of the writer invites students to take on a more active role, "deciding through practice how certain activities help or hinder one's own development of texts" (84). Brooke argues for the significance of this shift in pedagogy, noting, "it confronts students with a responsibility for their writing and learning which other classes do not" (84).

7. See also Patrocinio P. Schweickart's “Reading, Teaching, and the Ethic of Care," in which she interrogates various theories of reading in differing power situations. She advocates an ethic of care as an apt model for the instructor reading student papers (92). In this ethic of care, "although power is distributed in favor of the one caring, it is exercised in the service of the cared for" (91).

8. One of our discoveries about the students identified as not seeking help was that often they did seek feedback on their writing from friends, a situation about which the instructors were unaware. This phenomenon reinforced for us the limitations of our perspectives as teachers. We may assume a student is not collaborating with others because she does not approach us, participate enthusiastically in class writing groups, or visit the Writing Center. In reality, she simply may be seeking feedback outside of these "official" forums. We will explore the reason for this preference as we discuss Kathy's case further.

\section{Works Cited}

Anson, Chris M. "Response Styles and Ways of Knowing." In Writing and Response: Theory, Practice, and Research. Ed. Chris M. Anson. Urbana, Ill.: NCTE, 1989. 332-366.

Bartholomae, David. "Inventing the University." In When a Writer Can't Write: Studies in Writer's Block and Other Composing Process Problems. Ed. Mike Rose. New York: Guilford Press, 1985. 134-165.

Brand, Alice. "Social Cognition, Emotions, and the Psychology of Writing." Journal of Advanced Composition 11 (1991): 395-407.

Brooke, Robert E. Writing and Sense of Self: Identity Negotiation in Writ- 
ing Workshops. Urbana, Ill.: NCTE, 1991.

Grego, Rhonda, and Nancy Thompson. "Repositioning Remediation: Renegotiating Composition's Work in the Academy." College Composition and Communication 47 (1996): 62-84.

Herrington, Anne. "Reflections on Empirical Research: Examining Some Ties Between Theory and Action." In Theory and Practice in the Teaching of Writing: Re-thinking the Discipline. Ed. Lee Odell. Carbondale and Edwardsville: Southern Illinois UP, 1993. 40-70.

McLeod, Susan H. Notes on the Heart: Affective Issues in the Writing Classroom. Carbondale and Edwardsville: Southern Illinois UP, 1997.

Noddings, Nel. Caring: A Feminine Approach to Ethics and Moral Education. Berkeley: UC Press, 1984.

Rose, Mike. Lives on the Boundary: The Struggles and Achievements of America's Underprepared. New York: Free Press, 1989.

Schweickart, Patrocinio P. "Reading, Teaching, and the Ethic of Care." Gender in the Classroom: Power and Pedagogy. Urbana: U of Illinois Press, 1990. 78-95.

Shaughnessy, Mina. Errors and Expectations: A Guide for the Teacher of Basic Writing. New York: Oxford UP, 1977.

"Standards for Basic Skills Writing Programs." College English 41 (1979): 220-222.

Tobin, Lad. Writing Relationships: What Really Happens in the Composition Class. Portsmouth, NH: Boynton/Cook Heinemann, 1993.

Troyka, Lynn Quitman. "Perspectives on Legacies and Literacy in the 1980s." In A Sourcebook for Basic Writing Teachers. Ed. Theresa Enos. New York: Random House, 1987. 16-26. 


\section{Appendix 1}

\section{Writing Profile Name:}

For each question, please circle the letter or number that best describes your experience. Feel free to write comments in the space provided and on the back of this sheet. Thank you!

1. In general, do you prefer to work
a) alone
b) with others
c) it depends (please explain)

Comment:

2. In general, how much do you like to write?

$\begin{array}{lllll}\begin{array}{l}\text { I dislike } \\ \text { writing a lot }\end{array} & & & \begin{array}{l}\text { I enjoy } \\ \text { writing a lot }\end{array} \\ 1 & 2 & 3 & 4 & 5\end{array}$

Comment:

3. How easy or difficult is writing for you?

$\begin{array}{lllll}\begin{array}{l}\text { extremely } \\ \text { difficult }\end{array} & & & \begin{array}{l}\text { extremely } \\ \text { easy }\end{array} \\ 1 & 2 & 3 & 4 & 5\end{array}$

Comment:

4. How confident are you as a writer right now?

$\begin{array}{lllll}\begin{array}{l}\text { not confident } \\ \text { at all }\end{array} & & & \begin{array}{l}\text { extremely } \\ \text { confident }\end{array} \\ 1 & 2 & 3 & 4 & 5\end{array}$

Comment: 
5. How much do you expect your writing will improve this semester?

$\begin{array}{lllll}\text { not at all } & & & & \text { a lot } \\ 1 & 2 & 3 & 4 & 5\end{array}$

\section{Comment:}

6. In the past, which of these sources have you found are most helpful in improving your writing?

$\begin{array}{ll}\text { least } & \text { most } \\ \text { helpful } & \text { helpful }\end{array}$
a) family
1
2
3
4
b) friends (not in class)
1
2
3
4
c) classmates
1
2
3
4
d) teachers
1
2
3
4
5
e) tutors
1
2
3
4
5
f) other
1
2
3
4
5

\section{Comment:}

7. This semester, how helpful do you expect the following activities would be in improving your writing?

$$
\begin{aligned}
& \text { not at all } \\
& \text { helpful }
\end{aligned}
$$

A) Receiving feedback from:
a) family
1
2
3
4
b) friends (not in class) 1
2
3
4 

c) classmates
1
2
3
4
5
d) teachers
1
2
3
4
5
e) IDSC 100 student
assistant
23
4
5
f) Writing Center tutors
g) Others
1
2
3
4
5
1
2
3
4
5

B) Working on my writing on my own without seeking help from other people

not at all
helpful

1 extremely helpful

Please comment on back of page --

8. How likely are you to do the following things this semester?

$$
\begin{aligned}
& \text { not } \\
& \text { likely }
\end{aligned}
$$

extremely likely

A) Get help from others
a) family
1
2
3
4
5
b) friends (not in class)
1
2
3
4
5
c) classmates
1
2
3
4
5
d) teachers
1
2
3
4
5
e) IDSC 100 student
1
2
3
4
5 assistant 

f) Writing Center
tutors
1
2
3
4
g) Others
1
2
3
4
B) Work on my writing on my own without seeking out help from other people

5

$$
\begin{aligned}
& \text { not } \\
& \text { likely }
\end{aligned}
$$

1
3

Please comment on back of page -- extremely likely

\section{Appendix 2}

\section{Interview Questions}

1. Describe the writing process you used before taking the Intensive Writing course last semester. Did you work in groups? Did you do drafts? Did teachers or tutors offer help? Was the help required? Did you seek it out on your own?

2. Describe the writing process you use now for your college papers. Same follow-ups as question 1.

3. How would you describe yourself as a writer when you were in high school?

4. How would you describe yourself as a writer now?

5. In what kinds of situations (not just academic) do you ask for help?

6. In what kinds of writing situations do you ask for help?

7. Are you more or less likely to ask for help now? Why or why not? 


\title{
Deborah Rossen-Knill and Kim Lynch
}

\section{A METHOD FOR DESCRIBING BASIC WRITERS AND THEIR WRITING: LESSONS FROM A PILOT STUDY}

\begin{abstract}
We present a holistic method for describing basic writers and their writing to encourage classroom research at two- and four-year colleges, the most under-represented sites, and enable comparisons of basic writers across institutions. Our method grows out of a pilot study of basic writers and writing at two community and one four-year private college. It makes use of a survey to understand the basic writers' backgrounds; "back talk," through which students respond to our preliminary interpretations of the survey; and analysis of student writing for use of some conventional discourse features and for rate, type and seriousness of error. We offer some preliminary results from our pilot study to illustrate the type of findings our approach yields and highlight the importance of such findings to classroom instruction.
\end{abstract}

By now, it's obvious. A basic writer at, say, Harvard University in Cambridge, Massachusetts, is not the same as a basic writer at Cambridge Community College in northern, rural Minnesota - and we might have picked any number of institutions to make this statement. In fact, we've known for a while that the very term "basic writer" and the research-based generalizations about students identified as "basic writers" work against understanding the individual writers referred to by the name. As early as 1986, Jensen's "The Reification of the Basic Writer" problematizes the very act of characterizing basic writers as a group and makes clear that student learning is sacrificed by such actions. Jensen comes to this conclusion after discovering that descriptions of basic writers according to Meyer-Briggs personality types do not support the general descriptions in the literature. Recognizing the diversity of the group, Jensen argues, "Even when dealing with a single population, or a single class, it is dangerous, and more reductionist than descriptive, to characterize basic writers" (59-60). Only a year after Jensen, Troyka adds to Jensen's view the practical perspective of a writing instructor. She observes, "Often when I read a new article

At the time of this research, Deborah Rossen-Knill was the Writing Program Director at Philadelphia College of Textiles and Science. Since then, she served as the Director of Speaking and Writing at the University of Pennsylvania and has recently joined the University of Rochester as Director of College Writing. Kimberly Lynch is a full-time instructor of English and writing center director at Cambridge Community College. She received her doctorate in English, with an emphasis on basic writing, from the University of Minnesota. 
about basic writers, I think: 'Not the ones I know.'" In a pilot study investigating this observation, Troyka solicits 109 essays - half from two-year colleges and half from four-year colleges-along with low, medium and high rankings by the faculty submitting them. She then compares faculty rankings to high, medium and low rankings by her team of trained readers. The results show a significant difference between essay rankings in the two-year context and essay rankings from the four-year context, thus offering a concrete reason for us to heed Troyka's caution to be wary of generalizations about "basic writing" students, particularly in light of the far greater number of studies coming out of four-year institutions (9). Given these early and strong warnings against generalizing about basic writers - and there have been others (e.g., Minot and Gamble, Sohn), and given the evidence supporting these warnings, one might hope that we now have a substantial body of classroom-based research emerging from individual institutions, especially from the two- and four-year college teachers who devote much of their time to teaching basic writing.

More than a decade since these well-supported cautions against overly-general definitions of "basic writers," we have found ourselves still thinking, "Not the ones we know." Despite Lewis's findings that the majority of basic writing instruction takes place in community colleges, the majority of sessions on basic writers during the 1996 Conference on Composition and Communication - the event that inspired this work - were based in university research: 37 of the 49 papers on this subject were by researchers affiliated with research universities, six by those at four-year institutions, and six by teachers at two-year institutions. A random sample of five years of the Journal of Basic Writing ${ }^{1}$ also shows an unequal distribution. Of the thirty-five articles reviewed, thirty $(86 \%)$ of the authors were affiliated with a four-year institution, three $(9 \%)$ with a two-year institution, and two $(6 \%)$ were difficult to code because one individual taught at both a four-year and two-year college and conducted his research at the four-year college. The other author was affiliated with a two-year institution but did his research at a four-year college. In citing these tallies, we need to emphasize that we are not criticizing university researchers for doing research in their own institutions, which working conditions demand and the field justifiably expects. We include this tally simply to draw attention to the preponderance of university basic writers and basic writing instruction featured in published work: a selective group disproportionately represents the whole.

Wanting to work against this "reification of the basic writer" (Jensen) and toward increasing the body of basic writing research from instructors in two- and four-year institutions, we have sought to develop an instructor-friendly research method that would ultimately lead to descriptions of basic writers and their writing that could in- 
form classroom teaching and learning in local contexts. The first step in this process involves developing a research method that matches these goals. None of our tools is entirely new, and since we are not survey experts or statisticians, we do not advise on survey construction or data analysis. Rather, we advocate a holistic method of investigating basic writers and their writing and describe a set of tools for such a method.

Early on in our discussions about method we asked, What do we need to know to make informed choices about teaching and learning strategies? Answering this question with the help of past research has led us to develop a holistic method for learning about basic writers and their writing. No doubt, this need to know both writer and writing is apparent to most instructors. However, both Adler-Kassner's and Harrington's recent (1999) categorizations of basic writing literature point to a distinction between investigating the basic writer and investigating basic writing, with a call to return to the forgotten question, Who is the basic writer? While it is important for researchers to answer this question in a variety of contexts for the field to gain a national sense of the diversity of the basic writer, we are not in search of a national definition of "basic writer" or "basic writing"; rather, we are in search of a method for better understanding each basic writer and his or her writing in our respective institutions and classes. The key features of the method we believe can achieve this include the following:

1. a survey of the basic writer's background, followed by "back talk," a process that involves bringing our inferences from the survey about the basic writers' relationships to writ ing and the academic back to the students for their feed back,

2. text analysis, and

3. error analysis.

We begin learning about who our basic writers are through surveys (item 1), as have many researchers before us, but it is the "back talk" that draws the students' voices into our discussions about who they are and involves them in shaping their curriculum. This approach has some wonderful precedents, which, as a few examples make clear, vary in the way student feedback is brought back to the students. BuleyMeissner uses student-feedback from the Daly-Miller Measure of Writing Apprehension to engage students in discussion about how they can improve as writers over the course of the semester, with the result that students have a greater role in directing their own learning and lowering their writing anxiety levels. Haviland and Clark solicit student feedback on writing assessment exams and take this information directly into account as they rethink their pedagogy and redesign the 
exams. Yorio also solicits student feedback, in this case from adult ESL learners; however, in the end, the feedback relates only indirectly to the conclusion of his investigation. Yorio asks students to respond to the questions "If you were an ESL writing teacher at Lehman, what kind of course would you design? What kinds of materials would you use and what kinds of activities would you and your students engage in?" (36). At a later date, students are asked to complete a questionnaire that has them rank specific teaching practices, the large majority of which are drawn from responses on the open question. Interestingly, while it is the open-question responses that inform the studentquestionnaire, the study's conclusion - that there is a significant difference between instructors' and students' view of the effectiveness of particular teaching strategies - is not brought back to students. As a result, we are left to speculate about the reasons why the students focus on different teaching strategies or areas of focus than instructors. Is it, for example, because they view this exercise as a chance to say "Here is what we're missing and would like to learn," a message that might be diminished if they were to pay too much attention to those strategies that are prevalent in the class? Is it, as Yorio suggests, that they don't understand that they are in fact learning to address error or expand vocabulary, to take one example, because instruction is integrated into the critique of an essay as opposed to being presented as a separate exercise (41)? Is it something we haven't thought of? It might have been interesting to continue the conversation at this point, to bring the findings, the inferences, the conclusions, back to the students. As Harrington says, "If our program assessments and our curricula are not designed to permit students' voices to interact with our materials, we promote a stultifying position for student writers in our classes. This is not to say that students' voices are always right, but student voices deserve more of a place in our discourse" $(1999,102)$. Our method carves out a space for student voices to respond to our interpretations of their words, their lives and their relationships to writing and academia.

Our method for describing student writing involves text analysis (item 2) and error analysis (item 3). We analyze students' texts (as opposed to their errors) primarily to determine their familiarity with some essay features that are fundamental to a variety of writing forms and contexts, including introductions, conclusions, and use of examples. In addition, we consider broad aspects of their essays, such as overall number of words and paragraphs, as well students' topic choice when this serves as a way to learn about their backgrounds.

We also analyze rate and frequency of errors in essays, with the realization that many composition researchers and teachers believe that the study of error is inappropriate, if not useless, and that teaching grammar should be abandoned. We include error for two reasons. 
First, the error analysis allows for understanding of the students' writing in the context of past national studies of freshman college writing (Johnson, Witty and Green, Connors and Lunsford). Second, knowledge of our students' errors allows us to make informed decisions about how to (including whether or not to) address the issue.

Because our method grew out of a pilot study that we developed to investigate differences among three populations of basic writers, we offer as a bonus some examples of the types of findings this research might offer and how findings might relate to developing teaching strategies. Importantly, our consideration of teaching strategies should not be understood as suggestions on pedagogy, but only as examples of a small number of possible ways in which our findings can inform pedagogical choices. Ultimately, the results of this multidimensional approach may be used not only to understand writers at each institution, but also to make comparisons across institutions. Such comparisons let us gauge how well theories about any one group of basic writers and the instructional strategies which grow out of those theories can apply to another group of basic writers. ${ }^{2}$ Importantly, while we have found our method-our particular mix of tools-extremely useful, we do not suggest adopting it without consideration of the contexts in which it will be used.

\section{Chosen Institutions}

For the study which lead to the development of this method, we chose three post-secondary institutions: Cambridge Community College (CCC, 2-year rural), Minneapolis Community and Technical College (MCTC, 2-year urban), and Philadelphia College of Textiles and Science (PCTS, 4-year urban) ${ }^{3}$. We chose these colleges because they were not universities, they were deeply involved in basic writing instruction, and because we had easy access to them.

Cambridge Community College (CCC, 2-year rural) is a rural branch campus of a suburban Minnesota school; it is 50 miles north of Minneapolis, has $1300-1400$ students, and enrollment is growing steadily, even while numbers have declined in many Minnesota twoyear colleges. Forty percent of CCC (2-year rural)'s incoming students test into basic writing courses. About five percent of the students in a class have previously failed the course. CCC (2-year rural) has very few ESL students and no ESL program.

Minneapolis Community and Technical College (MCTC, 2-year urban) is in the heart of downtown Minneapolis; it's a recently merged community and technical college with approximately 12,000 students. Forty percent of MCTC's (2-year urban) incoming students test into one of two quarter-long basic writing courses. Again, about five per- 
cent of the students in a class have previously failed the course. While testing also offers some direction for placing students into ESL courses, ESL placement is not mandatory. The student can choose to take the ESL course first or to take only the basic writing course.

Philadelphia College of Textiles and Science (PCTS, 4-year urban) resides on the edge of Philadelphia; a four-year private college, it has 2600 undergraduates and 500 graduate students in master's programs. The college emphasizes an integrated liberal-professional education and is divided into five schools - General Studies, Architecture and Design, Business, Science and Health, Textiles and Materials Technology. At PCTS (4-year urban), about twenty percent of students test into one semester-long developmental writing course or a separate developmental ESL course if the testing indicates that they need the ESL version. During the spring semester of this study, some eighty percent of PCTS (4-year urban) students enrolled across the two nonESL basic writing courses had previously failed the course.

\section{Survey: Learning about Writers within and across Institutions}

In order to learn about basic writers at the three colleges, we conducted a survey that requested demographic, personal, and attitudinal information (see Appendix A). At each institution, we surveyed the students from two basic writing classes (27 students from CCC (2year rural), 23 from MCTC (2-year urban), and 17 from PCTS (4-year urban). ${ }^{4}$ A contextually-sensitive survey, one which may include both traditional demographic questions and those which seem locally relevant, offered a way to describe basic writers at a particular institution, speculate about what those descriptions might mean, and ask for back talk from them about those speculations. Finally, the survey data enabled us to compare basic writers from one institution to another.

\section{The Writer within the Institution}

A basic writer description offers a thumbnail sketch of students at a particular institution. At CCC (2-year rural), for example, our survey revealed that two-thirds of the basic writers were female, almost all were of white European descent, and their median age was 21 . While only $30 \%$ of these students were married, $41 \%$ of them were responsible for the care of one or more children. One striking piece of the CCC (2-year rural) surveys revealed that $27 \%$ of students' parents had not completed high school, with notable differences between the day and evening classes. While $37 \%$ of students' parents in the CCC (2year rural) evening class completed at least some form of post second- 
ary education, only $13 \%$ of students' parents in the day class had completed any post-secondary education.

Using the descriptions of basic writers that we created from interpreting background data, we developed theories about students' relationships with college work and life. This is not to suggest that these descriptions and speculations be used to prejudge students, but rather to open up a dialogue with them about what it means for them to be writers in college. With this latter goal in mind, we deliberately introduced back talk, a tool which would let us complete a full circle from student to researcher and back to student for at least a few of the survey interpretations.

\section{Back Talk and The Individual Basic Writer}

In a tape-recorded conversation, we presented the basic writers with facts from the survey and our speculations based on those facts and asked them to agree, disagree, or comment in any way they wished. The following student responses are chunked into conversational bites to show how this step can add texture to smooth, survey-based interpretations. Rather than organize their responses topically, we present them chronologically to give the reader a sense of their conversation as a whole.

The CCC (2-year rural) day class was presented with this fact: "It was uncommon for your parents to have completed any education beyond high school - only $13 \%$ of your parents did. My theory is that because your parents did not go to college, you might have difficulty knowing what it takes to be successful in college."

Student response 1: "I disagree. I see how my parents live and I don't want to be like them. At all. Because of my parents, I'm more intrigued to go to school because I don't want their lifestyle."

Student response 2: "Well, I'm just the opposite. I think that if I'd had parents that had gone to college it would have been in the atmosphere of the home and I would have gone up to the challenge sooner."

Student response 3: "And they can tell you what to expect where my parents can't."

Student 2 again: "Yeah, I'm first generation too, so it makes it even more difficult."

Student response 4: “Seeing my parents go to college shows me that they got a better paying job, and they got a better lifestyle because they went to college, and it was easier for them and they could help me with my homework and stuff 
so I may give that to my kids if I go to college I can help them and I can get a better paying jobs, a better chance at that."

Student response 5: "The fact that neither of my parents went to college it makes me stronger because I don't want to struggle the way they did. I want to get my career and get on get off on the right foot right away."

Another set of questions evolved from survey data which showed CCC (2-year rural) students working many hours, adding work obligations to the previous description which included family commitments as well. Again, differences between the day and evening CCC (2-year rural) classes emerged. Seventy-five percent of students in the evening class said they worked more than eight hours a day. That fact was repeated in this way to the night class: "You spend a significant amount of time (7-12 hours) working each day. My theory is that school is something you fit into your "spare time."

Student response 1: “Yes, that's true. You have to work it around it, your set work schedule. The work schedule is set. You have to tailor it to fit that."

Student response 2: "Cuts into my sleeping time."

A follow-up statement was made to probe deeper into their responses: "The second part of that theory is that you don't spend much time writing for this class."

Student response 1: "I would say that I don't spend much time writing it down on paper, but even when I'm busy doing other things such as working, in my mind, sometimes when I have the spare time at work, which brings in the spare time factor, I do tend to think about things that I could write about. The initial sitting down and being able to do it is very hard." Student response 2: "At my work I have ten hours to sit and do nothing basically but watch TV or read books so that's where I can spend my time writing there. Plus I have three or four days off, so therefore I have that time too. I would actually say that I have more time."

Student response 3: "I think the spare time isn't always available because of working full time, having families at home, and taking the other classes. It's not that we don't take the time but that we don't have the time to write as much as we would like to."

Based on our study, we firmly believe that back talk adds volumes to basic writer descriptions when the prompts for that student- 
researcher dialogue evolve, in context, from the students as they've presented themselves and their lives in survey data.

\section{Basic Writers across Institutions}

Another way survey information can be used is to look concretely at ways in which basic writers are similar to and different from one another. Traditional demographic data can be easily and fruitfully compared. For example, our pilot study showed that ethnic backgrounds, ages, marital status, and dependent child responsibilities varied widely among the three institutions, even between the two-year colleges which might be expected to have similar populations (for the breakdown of some of this data, see figures 1 and 2). Such comparative information should be considered when one institution or instructor hopes to imitate another institution's basic writing program or instructional model.

\section{Ethnic/Cultural Background}

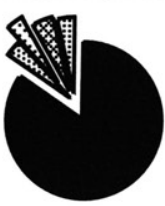

CCC

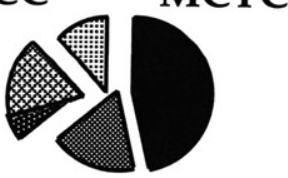

PCTS

MCTC

\section{(2) \\ (1)}

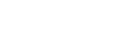

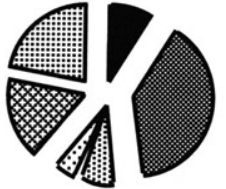

Figure 1: Ethnic/Cultural Background in Percentages

The importance of comparative analysis becomes clearer when one pauses to contemplate some of the differences among basic writers. The median ages, for example, were 26.5 at MCTC (2-year urban), 21 at CCC (2-year rural), and 18 at PCTS (4-year urban). In fact, PCTS (4-year urban) had no students over 20, and all of the respondents were single without children (Figure 2). Similarly, at both two-year institutions, most basic writers were single (Figure 2); however, forty-one percent of CCC (2-year rural) students and thirty-five percent of MCTC (2-year urban) students cared for children. Considered as a whole, the data showed that from PCTS (4-year urban) to MCTC (2-year urban) 
to CCC (2-year rural), an increasing number of students were adult members of their communities with work and family obligations outside of college, likely resulting in different relationships to college life and work.

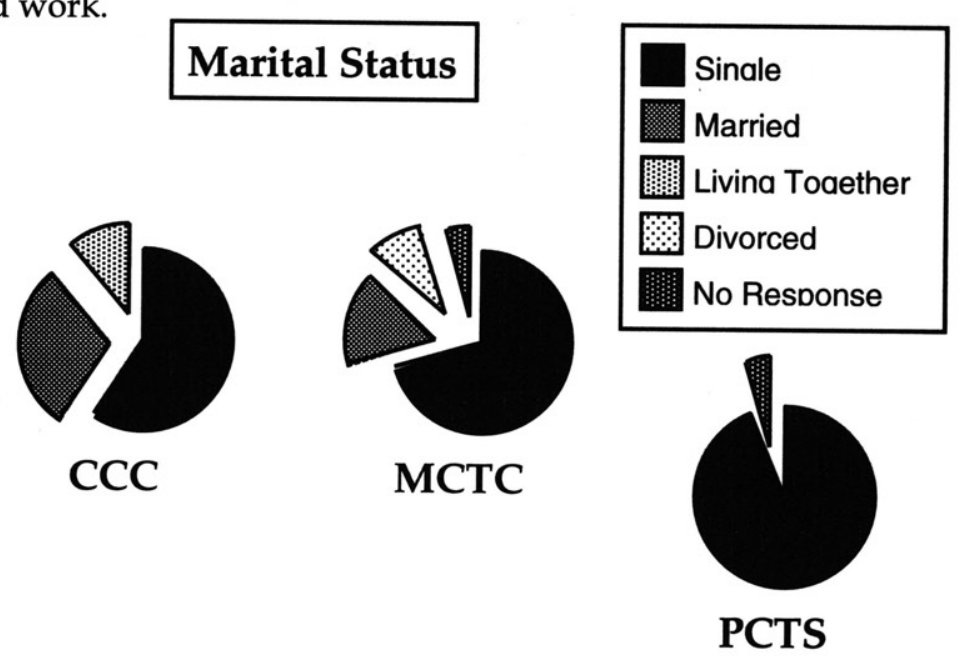

Figure 2: Marital Status

Being aware of differences in basic writers from one college to another while recognizing the individuality of basic writers at one's own institution can only lead to more thoughtful instruction. Of course, being just as thorough about understanding the features of the basic writing those students produce is equally important.

\section{Text Analysis}

So far, we have described a process for describing basic writers, using a demographic survey and back talk. To add to this description, we analyzed the writing collected from a subset of the same basic writers. We examined broad aspects of their diagnostic essays, including topic selection, discourse patterns and rate and frequency of errors and then considered how this kind of information might inform the way one teaches writing to the students at the different institutions.

The sample size for our pilot study was quite small, 10 essays from the basic writers at each institution. In choosing the essays for this study, we were particularly mindful of collecting samples that reflected the goals and methods of instruction at each institution. We decided not to develop one external prompt to be used at each institution, but rather collected the first piece of in-class writing assigned by the instructors. Certainly, this compromised our ability to compare writing across institutions, but we felt that the sacrifice was worth un- 
derstanding the students' writing as a function of the institution.

At MCTC (2-year urban), students wrote a diagnostic essay using an institutional prompt. The prompt asked students to write a paragraph characterizing their worst school experience and to "use examples, reasons, and details to support your main idea" (see Appen$\operatorname{dix} B$ ). The choice to elicit a narrative text was in keeping with these basic writing classes' usual approach to begin with and practice narrative before proceeding to expository or argumentative forms. CCC (2year rural) did not have any institutionally determined in-class diagnostic essay, but the class did typically begin with an in-class narrative. In this case, the instructor was able to administer the same prompt used at MCTC (2-year urban) for a first day writing exercise. At both MCTC (4-year urban) and CCC (2-year rural), the essays were not timed, per se, but they were limited to about forty minutes of remaining class time. No students were allowed to continue writing when the class ended. There were no concrete benefits or drawbacks (e.g., high or low grade) linked to the students' essays at either institution.

PCTS (4-year urban) students' first in-class writing was a diagnostic exam that served as a back-up test to the placement exam (see Appendix C). Intended to elicit an argumentative essay, the prompt asked students to take a position on one of two possible topics and then argue for that position in fully developed, well-supported examples. PCTS (4-year urban) students were given 45 minutes to write their essays and had tremendous incentive to do well, as a successful essay might lead to placing out of the developmental class and into the first-year writing course. Overall, the writing situation at PCTS (4year urban) urged the student to produce the best piece of writing possible (which, of course, does not always lead to the student producing his/her best work).

We first looked at essays to gain a broad understanding of students' familiarity with academic communities and discourse. Specifically, we identified students' topics, considered essay length to gain some sense of students' fluency, and looked at the number and length of paragraphs in texts, as paragraphs are an essential and basic part of academic essays. We then examined students' use of a few conventions fundamental to most writing: introductions, conclusions and examples. We also conducted an error analysis, in part to understand the students' writing in the context of past national studies of freshman college writing (Johnson, Witty and Green, Connors and Lunsford).

\section{Students' Topics in Narrative Essays}

Since one purpose of this study was to describe students at each 
institution, it made sense to look at the CCC (2-year rural) and MCTC (2-year urban) students' personal narratives in response to the "worst school experience" prompt. As we read through all of those essays, we came to realize the value of this approach in revealing students' thoughts about their own lives, about learning experiences, and about academic institutions.

CCC (2-year rural) and MCTC (2-year urban) students produced a remarkable range of topics that reached as far back as one five-yearold's first day of school, as well as addressing recent experiences at the colleges under study. Not surprising to any of us who have suffered "fear of school" dreams, several papers from both institutions spoke of classic school traumas, including feeling lost in school, missing the bus, going to the wrong class, experiencing first day fear, and witnessing a dissected frog begin to move. Another group of worst school experiences shared by CCC (2-year rural) and MCTC (2-year urban) students might be named public humiliations in school. These involved slipping, throwing up, and discovering one's bra outline showing during a speech. There were also a few love problems at each college.

Although many topics from the MCTC (2-year urban) and CCC (2-year rural) writing samples were similar, some seemed distinctly different. Whereas CCC (2-year rural) students focused primarily on school-based events, such as walking down the hallway or giving a speech (the one exception is an account of an abusive boyfriend), MCTC (2-year urban) students often discusseủ topics more clearly connected to their socioeconomic situations or their lives in other countries. One student was ashamed of clothing that was shabby because he was on welfare; a student from Kenya talked of having no school to attend because he was in a refugee camp for two years. Another student, while living in a different country, skipped school and was beaten by the principal, and another, who was also living in a different country at the time of his story, told of staying up all night to protect the school because that's what students had to do. There were also accounts of prejudice, as well as six accounts of violence. At MCTC (2-year urban), even though the prompt asked students to focus on school, life outside of school - often in another country - clearly played a central role in their "worst school experience."

\section{Number of Words and Paragraphs per Essay}

Reviewing even short writing exercises for choice of topic revealed a remarkable range of ideas and individuals, but it didn't say much about the students' writing fluency (in fact, there was not even one narrative about writing). To address this, we looked at how much students wrote, on the assumption that those most comfortable express- 
ing ideas in writing would write more words and a greater number of paragraphs in a given amount of time. Unfortunately, differences in the prompts made it difficult to draw conclusions. The PCTS (4-year urban) prompt asked for an essay, whereas the other two prompts called for a paragraph. One would expect longer products given the prompt for an essay.

In response to the same prompt, CCC (2-year rural) students wrote substantially more words than MCTC (2-year urban) students. However, this may well be the result of a variation in the presentation of the prompt at each institution. At CCC (2-year rural), the prompt was presented on half sheet of printer paper, and students responded on lined tablet paper provided by the instructor. The instructor gave each student a few sheets of paper and told them that they could ask for more if they needed it. The presentation of the prompt did not overtly suggest how much the student should write. This was not the case at MCTC (2-year urban), where the prompt was presented as the top part of an otherwise ready-to-be filled lined piece of paper, implying "this is how much space you should fill." Very few students went beyond that space - a clear lesson for future studies. Without question, variations in prompts resulted directly from our decision to work within the context of each institution's and each class's instructional goals and methods, to interfere as little as possible, but we might have interfered just a bit in this case and ended up with significantly more useful results.

\section{Introductions and Conclusions}

In designing the pilot study, we wanted, among other things, to address some skills fundamental to a variety of writing forms and contexts. We first investigated whether or not the students generally wrote introductions and conclusions, if they had a sense of the need to open and close a piece of writing. We defined an introduction as opening text that identifies the topic to be discussed in the essay. As a response to the prompt about the worst school experience, for example, the opening text would count as an introduction if it mentioned the worst experience or the specific experience, as in this example from a CCC (2-year rural) student: "Once in a English Class I was giving a speech, and I lost my voice and couldn't finish given it."

The introductions in the argumentative essays were typically full paragraphs and in some cases longer, as this next example from a PCTS (4-year urban) student illustrates:

Technology has a great influence on our lives, especially when the wrong people get a hold of it, they tend to abuse it. Take 
for example the defense of our country, and the military. With technology and hard work, we have made the United States the most powerful country in the world. That is one of the great examples of technology having a good influence. It's when leaders from other terroristic countries get a hold of it, that's when technology is bad.

Bot that is only one example of many things technology has done for the world. The good, definitly out weigh the bad.

Although it took this student several sentences and more than one paragraph to develop his "thesis," he/she did begin this paper by presenting the view of technology that is developed in the main text. For this reason, we determined that this essay did have an introduction. In cases where students presented a series of examples and/or opinions without any overarching statement, we did not consider the opening text an introduction.

Conclusions were defined similarly to introductions: a conclusion involves final text that generalizes the previous discussion to say something about that discussion, even if the closing text does not differ significantly from the introductory text. A simple That was my worst school experience would suffice. To conclude the discussion of the awful experience with giving a speech in an English class, the CCC (2year rural) student did actually go beyond repeating the introduction to comment on the event: "I did pass, but from then on I hated to give speeches in front of people and I still hear about it from friends that were in that class with me." To conclude the discussion about the pros and cons of technology, the PCTS (4-year urban) student previously quoted wrote:

Now that we are in the computer age, by learning what these machines can do, it only makes us that much smarter. Even though they do have some disadvantages and problems, the overall picture is very positive. By creating this kind of technology, it has only made this country, much smarter, and powerful.

In keeping with our definition of conclusion, the student stepped back to make a final judgment: "the overall picture is very positive." Through this generalization, the student demonstrated the fundamental function of a conclusion.

At all three institutions, the majority of students demonstrated a basic sense of essay structure, of beginning, middle and end. At CCC (2-year rural), eight of the ten essays have introductions, and eight of ten have conclusions; at MCTC (2-year urban), nine of ten have introductions, and eight of ten have conclusions; and at PCTS (4-year ur- 
ban), all essays have introductions and conclusions. Equipped with this kind of information, an instructor could enrich the students' skills in these areas and draw parallels between the form and function of introductions in different kinds of writing to help students build on what they know and become more flexible writers. Equally important, used as a diagnostic, this kind of text analysis can help instructors quickly identify and tutor those few basic writers who are least familiar with those basic discourse conventions.

\section{Examples}

In our work with teaching and program administration, we have frequently encountered "example," "support with example," "more examples," and the like in marginal comments from instructors to students. Because of this, we began to wonder to what extent writers in our study used this basic explanatory tool. Specifically, we looked at how often a writer used examples (a skill called for in all prompts (Appendix $B$ and $C$ )), at the number of words per example as a measure of development, at the writer's movement into and out of examples, and at whether or not the example was discussed in terms of the paper topic.

Primarily interested in whether or not students had a basic familiarity with producing examples in writing, we defined this feature as a reference to or description of a specific instantiation of an idea. The idea could come before or after the example. The transitions into and out of examples were defined quite liberally: any text that was linked to the example and that referred to the idea being exemplified counted as a transition. The following example from a PCTS (4year urban) essay will help clarify our definitions:

Since then, we have seen a lot of things arise that are only beneficial to us, the people, not the trees, plants, animals or even our atmosphere. Some things are vehicles, t.v.s, vcr's, computers, etc...

The first sentence presents the idea; "some things" serves as a transition linking the examples to come back to the "things" discussed in the first sentence; and "vehicles, t.v.s, ..." serve as the concrete instantiation of "things," or the example. In this case, the student does not offer any transition between the end of the example and the following text, nor is there any discussion of the example with respect to the topic. Rather, the student moves immediately into a new paragraph and a new take on the general idea that technology is bad: "Personally, I have a hard time understanding why the way of life today 
sees modern technology as a necessity. It seems to me that because of all the material things around us, just about all of us are selfish and looks at life as a game."

Using this approach to analyze examples led to a useful overview of how examples were used by each group of students (see table 1).

\begin{tabular}{llll}
\hline Use of Examples $\begin{array}{c}\text { CCC } \\
\text { (2-year rural) }\end{array}$ & $\begin{array}{c}\text { MCTC } \\
\text { (2-year urban) }\end{array}$ & $\begin{array}{l}\text { PCTS } \\
\text { (4-year urban) }\end{array}$ \\
\hline $\begin{array}{l}\text { \# of examples } \\
\text { \# of words devoted }\end{array}$ & 10 & 11 & 25 \\
$\quad$ to examples & 1838 & 1154 & 686 \\
$\begin{array}{l}\% \text { of words devoted } \\
\text { to examples }\end{array}$ & $74 \%$ & $76 \%$ & $22 \%$ \\
$\begin{array}{c}\text { Transition into } \\
\text { example exists }\end{array}$ & 8 & 9 & 21 \\
$\begin{array}{c}\text { Transition from } \\
\text { example to Para- } \\
\text { graph or paper topic }\end{array}$ & 7 & 8 & \\
$\quad$ exists & & \\
$\begin{array}{c}\text { Example discussed } \\
\text { in terms of topic }\end{array}$ & 7 & 1 & 11 \\
\hline
\end{tabular}

Table 1: Use of Examples in Basic Writing at CCC (2-year rural), MCTC (2-year urban), and PCTS (4-year urban)

Though our small sample size and variations in essay prompts prevented us from drawing conclusions, our results did suggest the kind of information this type of research yields. We found, for example, a striking difference between PCTS (4-year urban) and the two community colleges: even though PCTS (4-year urban) had by far the greatest number of words per student paper and a greater number of examples per paper, PCTS (4-year urban) had dramatically fewer number of words devoted to examples. Such a result in a larger study might reveal under what circumstances students are and are not able to develop examples and to what extent this ability is a function of essay form or content, or, as one reviewer pointed out, the relationship between the demands of the exam question and the allowed writing time.

We also found that transitions into examples were quite common, whereas transitions out of examples were noticeably few in the argumentative essays from PCTS (4-year urban). When it came to the task of discussing an example, CCC (2-year rural) students demonstrated greater skill than did MCTC (2-year urban) students. More often than not, PCTS (4-year urban) students did not discuss examples.

Considered as a whole, what might these various pieces of information about introductions, conclusions, and examples say about a 
writer? If we look only at the CCC (2-year rural) writers for the sake of demonstration, this pilot suggests that CCC (2-year rural) students have a good grasp of the basic structure and a number of parts of a narrative essay and can move well from the abstract to the concrete and back again in the process of developing a single idea. With such information (verified, of course, by a larger study), an instructor could start working from what the students can do in the narrative framework and help them transfer those skills to other writing forms and contexts.

Such individual and institutional descriptions might also help us understand and articulate differences and similarities across groups of basic writers. As did CCC (2-year rural) students, the majority of MCTC (2-year urban) students demonstrated a familiarity with the concept of the introduction and conclusion, with moving into and out of examples in a limited way, and with moving from an idea to a concrete example and back again. However, MCTC (2-year urban) students differed in that they did not typically discuss examples. This information suggests that this group might do well to work within the narrative framework to practice relating examples to the essay's topica very different approach than that suggested by the CCC (2-year rural) information.

\section{Error Analysis}

To offer several views into the writing of basic writing students, we also analyzed the type, frequency, and seriousness of error in students' essays. This involved reading through all of the essays in classes at each institution and making a list of every error found. From this list, we developed a template of the twenty most frequent errors made at each institution. We then used this template (see Appendix D) to analyze 10 randomly selected essays from each college.

While we do not think it useful or appropriate to report all the results of this study, we do think it worth pausing to note the error rates we determined in comparison to past error analyses of first-year college and University writers (Johnson; Witty and Green; Connors and Lunsford) (see table 2).

\begin{tabular}{ccccccc} 
& \multicolumn{3}{c}{ CCC MCTC PCTS Johnson Witty \& } & $\begin{array}{c}\text { Connors \& } \\
\text { Creen }\end{array}$ & Iunsford \\
\cline { 2 - 7 } Errors/100 words & 8.10 & 19.00 & 10.20 & 2.11 & 2.24 & 2.26 \\
\hline
\end{tabular}

Table 2: Errors per 100 Words in This Study and Previous Studies

Compared to the number of errors noted in studies of first-year 
college-level writers, the error rate per 100 words for our basic writers was quite high for each institution. In 1917, Roy Ivan Johnson looked at 198 papers from sixty-six freshmen and found an error rate of 2.11 errors per 100 words. In 1930, Paul Witty and Roberta Green looked at 170 papers written by freshman, and they found about 2.24 errors per 100 words (qtd. in Connors and Lunsford). In Connors and Lunsford's 1986 national study of 3,000 papers, they found an error rate of 2.26 errors per 100 words. In our study, the best basic writer certainly tripled and others often quadrupled the error rate of the average freshman writer in these national studies spanning nearly 70 years.

To measure error frequency in the ten sample papers from each class, we identified the number of total errors in the papers and the number of papers with specific errors. This second frequency rating was included to make it possible to think beyond how many errors were being made by a group in order to consider how many students in the class were making the same errors, an especially important piece of information for designing classroom instruction.

After determining overall error frequency rates, we determined frequency rates for specific constructions and rated errors according to their perceived seriousness (Noguchi, Hairston). Our interest in ranking seriousness grew out Noguchi's observation during his 1996 CCCC presentation that in deciding which errors to address when teaching writing, instructors should certainly teach students to understand and correct those errors which produce strong negative reactions, as well as those which occur with high frequency. To determine which errors produced strong negative reaction, we looked to Maxine Hairston's "Not All Errors are Created Equal: Nonacademic Readers in the Professions Respond to Lapses in Usage." Hairston surveyed eighty-four business and industry professionals and asked them to respond to sixty-five different language constructions and determine whether they bothered the reader a lot, a little, or not at all. From this, Hairston developed a rating system describing the relative seriousness of various types of error in the professional world, ranging from "outrageous" to "unimportant." In a complementary study, Donald Ross, Jr. discovered that in a business letter, errors do affect the reader's impression of the writer. He found that spelling errors caused the strongest negative reaction and that all types of error were wrongly interpreted by readers as spelling errors $(167,172)$. It should also be pointed out that many of the errors found in our pilot study were not rated by Hairston's or Ross's study, so we do not offer any information about the relative seriousness in these cases, except to suggest that the reader consider his or her own response to them.

As tables 3, 4, and 5 illustrate, error analysis allowed for a close look at abilities within and across institutions. 


\begin{tabular}{|c|c|c|c|c|}
\hline \multirow{2}{*}{$\begin{array}{l}\text { CCC (2-year rural) } \\
\text { Error or Error Pattern } \\
1: \text { No comma after }\end{array}$} & $\begin{array}{l}\# \text { found in } \\
10 \text { papers }\end{array}$ & \multirow[t]{2}{*}{$\begin{array}{l}\% \text { of total } \\
\text { errors }\end{array}$} & \multicolumn{2}{|c|}{$\begin{array}{l}\text { \# of papers degree of } \\
\text { with error seriousness }\end{array}$} \\
\hline & & & & \\
\hline $\begin{array}{l}\text { intro element } \\
\text { Spelling }\end{array}$ & 42 & $20.9 \%$ & 9 & Med/Low \\
\hline : No comma in com- & 40 & $20.0 \%$ & & Serious \\
\hline $\begin{array}{l}\text { pound sentence } \\
\text { No comma (non- }\end{array}$ & 25 & $12.4 \%$ & 9 & No rating \\
\hline restrictive or series & 15 & $7.5 \%$ & 6 & $\mathrm{M} / \mathrm{L}$-serious \\
\hline 5: Tense/aspect problem & 15 & $7.5 \%$ & 4 & Serious \\
\hline 6: Comma splice & 12 & $6.0 \%$ & 5 & Med/Low \\
\hline $\begin{array}{l}\text { 7: Articles wrong or } \\
\text { missing }\end{array}$ & 10 & $5.0 \%$ & 2 & No rating \\
\hline $\begin{array}{l}\text { 8: Wrong/missing/ } \\
\text { extra word }\end{array}$ & 9 & $5.0 \%$ & 4 & Serious \\
\hline $\begin{array}{l}\text { 9: Possessive apostro- } \\
\text { phe error }\end{array}$ & 7 & $3.5 \%$ & 4 & No rating \\
\hline wrong or missing & 6 & $3.0 \%$ & 2 & Serious \\
\hline
\end{tabular}

Table 3: Top Ten Errors in Developmental Writing at CCC

Three of the ten errors in table 3-spelling, tense/aspect problem, and wrong/missing/extra word - were serious. Hairston rates some spelling errors as being more serious than others (796-798). For instance, an its/it's error is not rated as being particularly serious, but affect/effect is considered serious. It should be noted that, according to our observations and her discussion of the study, Hairston did not include test sentences with simple spelling errors (e.g. recieved for received). Hers were either homonym or spelling/punctuation errors. In the open-ended section of the questionnaire, however, several of her respondents singled out spelling as "the most annoying error they encountered" (798). For those reasons and based on Ross's complementary study, we ranked spelling as a serious error. With reference to non-spelling errors, fewer than half of the CCC (2-year rural) writers produced serious errors, and the number of serious errors was relatively low. CCC (2-year rural) students did make two unique types of error, that is, errors that were not part of the top ten at either MCTC (2year urban) or PCTS (4-year urban). These involved the comma splice and the possessive apostrophe. In general, CCC (2-year rural) students produced relatively few serious errors compared to MCTC (2year urban) and PCTS (4-year urban). 


\begin{tabular}{|c|c|c|c|c|}
\hline $\begin{array}{l}\text { MCTC (2-year urban) } \\
\text { Error or Error Pattern }\end{array}$ & $\begin{array}{l}\text { \# found in } \\
10 \text { papers }\end{array}$ & $\begin{array}{l}\% \text { of tota } \\
\text { errors }\end{array}$ & $\begin{array}{l}\text { \# of pape } \\
\text { with error }\end{array}$ & $\begin{array}{l}\text { ers degree of } \\
\text { seriousness }\end{array}$ \\
\hline \multicolumn{5}{|l|}{ 1: No comma after } \\
\hline intro element & 30 & $13.6 \%$ & 8 & Med/Low \\
\hline Tense/aspect problem & 27 & $12.0 \%$ & 7 & Serious \\
\hline Improper verb form & 27 & $12.0 \%$ & 6 & Med-Outrg \\
\hline 4: Spelling & 23 & $10.4 \%$ & 6 & Serious \\
\hline Wrong/missing/ & & & & \\
\hline $\begin{array}{l}\text { extra word } \\
\text { Prepositions }\end{array}$ & 18 & $8.2 \%$ & 7 & Serious \\
\hline wrong or missing & 15 & $6.9 \%$ & 6 & Serious \\
\hline $\begin{array}{l}\text { 7. Run-on or fused } \\
\text { sentence }\end{array}$ & 15 & $6.9 \%$ & 5 & Serious \\
\hline $\begin{array}{l}\text { 8: No comma in com- } \\
\text { pound sentence }\end{array}$ & 14 & $6.4 \%$ & 8 & No rating \\
\hline $\begin{array}{l}\text { 9: No comma (non- } \\
\text { restrictive or series) }\end{array}$ & 7 & $3.2 \%$ & 5 & M/L-serious \\
\hline $\begin{array}{l}\text { 10. Articles wrong or } \\
\text { missing }\end{array}$ & 5 & $2.3 \%$ & 4 & No rating* \\
\hline
\end{tabular}

Table 4: Top Ten Errors in Developmental Writing at MCTC *While error pattern \# 10 received no rating in Hairston's study, article problems are very typically E.S.L problems, and we suspect would fall under her classification of status-marking errors which proved to be "outrageous" in their level of seriousness.

MCTC (2-year urban) basic writing students produced a greater number of serious errors with higher frequency than their CCC (2year rural) and PCTS (4-year urban) counterparts. The tense/aspect problem, ranked second, was identified as serious by Hairston and occurred with high frequency: seven out of ten students produced this error, and $12.3 \%$ of the group's total errors fell into this category. Improper verb form, ranked third and also occurring with high frequency, may be very serious, particularly when it involves verb usage associated with particular socioeconomic or cultural groups, what Hairston calls "status verbs." As noted earlier, spelling may or may not be serious. Run-on or fused sentences were ranked as very serious, and half the students produced such structures. Having no comma in a series was also considered a serious error, and again, half-the-students made this mistake. Unique errors for this group were the run-on or fused sentences and improper verbs, both of which may be fairly serious. Clearly, MCTC (2-year urban) students produced a lot of serious errors with high frequency. 


\begin{tabular}{|c|c|c|c|c|}
\hline $\begin{array}{l}\text { PCTS (4-year urban) } \\
\text { Error or Error Pattern }\end{array}$ & $\begin{array}{l}\text { \# found in } \\
10 \text { papers }\end{array}$ & $\begin{array}{l}\% \text { of total } \\
\text { errors }\end{array}$ & $\begin{array}{l}\text { \# of pape } \\
\text { with error }\end{array}$ & $\begin{array}{l}\text { ers degree of } \\
\text { seriousness }\end{array}$ \\
\hline 1: Spelling & 58 & $18.5 \%$ & 9 & Serious \\
\hline $\begin{array}{r}\text { 2: No comma after } \\
\text { intro element }\end{array}$ & 39 & $12.4 \%$ & 10 & Med/Low \\
\hline $\begin{array}{l}\text { 3: No comma (non- } \\
\text { restrictive or series) }\end{array}$ & 17 & $5.4 \%$ & 7 & M/L-serious \\
\hline $\begin{array}{l}\text { 4: Wrong/missing/ } \\
\text { extra word }\end{array}$ & 15 & $4.8 \%$ & 7 & Serious \\
\hline $\begin{array}{l}\text { 5: Prepositions } \\
\text { wrong or missing }\end{array}$ & 12 & $3.8 \%$ & 6 & Serious \\
\hline $\begin{array}{l}\text { 6: Extra commas } \\
\quad(\text { between } \mathrm{p} / \mathrm{c}, \mathrm{s} / \mathrm{v})\end{array}$ & $12(6 / 6)$ & $3.8 \%$ & 5 & Serious \\
\hline $\begin{array}{l}\text { 7: No comma in com- } \\
\text { pound sentence }\end{array}$ & 12 & $3.8 \%$ & 5 & No rating \\
\hline 8: Tense/aspect problem & 11 & $3.5 \%$ & 4 & Serious \\
\hline $\begin{array}{l}\text { 9: Non-parallel structure } \\
\text { 10: Vague pronoun }\end{array}$ & e 10 & $3.2 \%$ & 5 & Serious \\
\hline reference & 8 & $2.5 \%$ & 5 & No rating \\
\hline
\end{tabular}

Table 5: Top Ten Errors in Developmental Writing at PCTS (4-year urban)

The student writing samples from PCTS (4-year urban) revealed a fair number of serious errors, but no errors that fell into Hairston's "very serious" or "outrageous" category. Spelling problems (of varied seriousness) accounted for the largest proportion of errors. Two less frequent but "serious" errors included missing a comma in a series and including an extra comma between the predicate and complement (e.g., This is the boy, that Sue knows.). It is worth noting that six out of the twelve errors of this sort were actually subject/predicate comma splits, which were not specifically ranked by Hairston. Also on the top-ten errors list, the serious tense/aspect problems and non-parallel structures appeared in five out of the ten papers reviewed. Unique errors for PCTS (4-year urban) students included non-parallel sentence structure, vague pronoun reference, and extra commas.

The worth of the error analysis can be found not only in what it reveals about each student's writing ability, but in what it suggests about basic writers as a group: not all basic writers make the same kind of errors (Tables $3,4,5)$, making any single approach to teaching them suspect. Joseph Harris discusses three major metaphors that have dominated the field and had a strong impact on writing instruction-growth, initiation, and conflict (29). In nearly all approaches represented by those metaphors, language use at the sentence level or 
lower is typically addressed at the end of the course, possibly too late to adequately address the issues at hand. Our research supports a different approach: the instruction for any class of students should depend on the students' actual writing abilities. The CCC (2-year rural) classes with relatively low frequency of serious errors may find it a poor investment to address usage errors in a class context, opting instead for a more individualized approach. MCTC (2-year urban) classes with relatively high frequency of serious errors (and students with many outside obligations and minimal time for individual tutoring) may, on the other hand, determine it worthwhile to address usage early on and throughout the quarter or semester. It is this kind of holistic view of the student we hope to encourage as we design our teaching and learning strategies.

\section{Final Thoughts}

Offering feedback on an earlier version of this paper, Don Ross, Director of the Upper Division Composition and Communication Program at University of Minnesota during the tenure of Director Chris Anson, asked us a seemingly simple question: are the institutions studied here meant to be representative of certain kinds of institutions? If so, should we refer to them more generally - that is, replace the acronym MCTC (which is how we referred to Minneapolis Community and Technical College in earlier drafts) with "2-year urban," CCC with "2-year rural," and PCTS with "4-year private urban." He felt the change would help people remember which college was which. Formulating an answer to this apparently simple question helped us to articulate the strengths of our research method. If we replaced MCTC with "two-year urban institution," for example, we might wrongly imply that MCTC could in fact fairly represent all members of "twoyear institutions," but if we only used MCTC, we might risk sending the untested message that MCTC could not in any way represent "twoyear urban" institutions. The answer, then? At the risk of wordiness, we chose to refer to the college using the acronym and the descriptor, thus using "MCTC, 2-year urban," for example. Similarly, as we developed our research method, we felt that only investigating the basic writer or piece of writing at the individual level, or only within the confines of a single institution, or only across institutions would fail to offer a complete enough picture of basic writers. In fact, as we investigated the basic writer from a number of personal and text-based perspectives, we learned that the view of basic writers and basic writing is quite mutable. The CCC (2-year rural) student represented by the survey, for example, differed from the CCC (2-year rural) student represented through back talk; the overall error rates for basic writers 
across institutions represent basic writers quite differently than the analysis of the basic writers at any one of the institutions. To understand and teach responsibly to the basic writer, we must understand him or her as an individual writer, as a writer within an institution, and as a member of a larger group of writers who share a particular range of skills.

Not surprisingly, as we sought to learn about basic writers as a group, we confronted the greatest objection to our work. We posted a general, institution-centered survey on both the Basic Writing and Writing Program administrator list servers, asking how those teaching in or directing basic writing courses would describe their students. We asked, among other things, "While this may seem almost impossible, try to describe a 'typical' basic writing student at your institution in terms of individual characteristics, life circumstances, and his/ her writing abilities." Typical comments from the seven who responded were: "first generation college working class backgroundoften second or third generation in U.S." and "large nontraditional population but BW are overwhelmingly traditional age." One comment stood out: "this is almost impossible, and I think, possibly pernicious. The last thing in the world we want to do is to pathologize 'basic' writers by sorting them into various demographic categories. (Sorry for being difficult)."

It is a difficult issue. We understand and, to a certain extent, agree that it could be dangerous business to classify or pigeonhole basic writers. Nevertheless, taking time to know more about the actual students we've already identified as needing extra help to write successfully in college strikes us as a responsibility, a way to do as Ann Berthoff suggests - "to begin where they are" both in life circumstances and writing proficiencies.

\section{Notes}

1. To complete the random sampling, a number was assigned to the 70 selections from Spring '93 issue through Spring '98 issue. Everything which had an author listed in the table of content (articles, responses) was counted, but a special Mina Shaughnessy reprint section of her work from the 1970s was not. To select 35 articles for review, we used the random sampling table in Lauer and Asher, Composition Research, resulting in the following list of authors: Adams, Berthoff, Biser, Bloom, Cody, Creed and Andrews, Crowley, Dykstra, Elliot, Fitzgerald, Fox, Gaillet, Hilgers, Hindman, Laurence, Maher, Marinara, Miraglia, Mlynarczyk, Moran, Newman, Norment, Parisi, Purves, Roy, Scott, Segall, Servino (1994), Servino (1996), Sheridan-Rabideau and Brossell, Sirc, Wiener, Winslow, Wolcott, Young. The confidence lim- 
its for this data, with the correction factor, are $+/-12$ percent.

2. The small number of basic writers studied restricts conclusions which can be drawn from the data in these ways: for survey information and topic analyses, the sample of CCC (2-year rural) and PCTS (4-year urban) students is equal to the population as a whole, so conclusions can be drawn, but for MCTC (2-year urban), the sample size does not approach the size of the population and is therefore unreliable; similarly, the number of writing samples analyzed (10) is too small across all institutions, but is more reliable for CCC (2-year rural) and PCTS (4year urban) because it represents $37 \%$ and $59 \%$, respectively, of the entire population during the academic term of the study.

3. Philadelphia College of Textiles and Science was granted university status July 13, 1999.

4. At CCC (2-year rural), those two classes included all basic writers being served at the college that quarter; technically, the course being offered (Eng 090) is the higher of two levels in the college catalog, but because CCC (2-year rural) cannot sustain enrollment in its lowestlevel course (Eng 089), all developmental writers at CCC (2-year rural) end up in Eng 090; at MCTC (2-year urban), we use data from the lowest of two levels of developmental courses; at PCTS (4-year urban), we examine data from non-ESL developmental classes.

\section{Works Cited}

Adler-Kassner, Linda. "Just Writing, Basically: Basic Writers on Basic Writing." Journal of Basic Writing 18.2 (1999): 69-90.

Berthoff, Ann E. "What Works? How Do We Know?" Journal of Basic Writing 12.2 (1993): 3-17.

Buley-Meissner, Mary Louise. "'Am I Really that Bad?': Writing Apprehension and Basic Writers" Journal of Basic Writing 8.2 (1989): 320.

Connors, Robert J. and Andrea A. Lunsford. "Frequency of Formal Errors in Current College Writing, or Ma and Pa Kettle Do Research." College Composition and Communication 39 (1988): 395-409.

Hairston, Maxine. "Not All Errors are Created Equal: Nonacademic Readers in the Professions Respond to Lapses in Usage." College English 43 (1981): 784-806.

Harrington, Susanmarie. "The Representation of Basic Writers in Basic Writing Scholarship, or Who is Quentin Pierce?" Journal of Basic Writing 18.2 (1999): 91-107.

Haviland, Carol Peterson and J. Milton Clark. 'What Can our Students 
Tell us about Essay Examination Designs and Practices." Journal of Basic Writing 11.2 (1992): 47-60.

Jensen, George H. "The Reification of the Basic Writer." Journal of Basic Writing 5.1 (1986):52-64.

Journal of Basic Writing 12.1 (1993) through 17.1 (1998)

Lauer, Janice and J. William Asher. Composition Research: Empirical Designs. New York: Oxford University Press, 1988.

Lewis, Laurie, Elizabeth Farris, and Westat, Inc. Remedial Education at Higher Education Institutions in Fall 1995. National Center for Education Statistics, U.S. Department of Education, 1996.

Minot, Walter S. and Kenneth R. Gamble. "Self-Esteem and Writing Apprehension of Basic Writers: Conflicting Evidence." Journal of Basic Writing 10.2 (1991): 116-124.

Ross, Donald. "A Brief Note on How Writing Errors are Judged." Journal of Technical Writing and Communication 11.2 (1981): 163-173.

Sohn, Katherine K. "Rural Whites: A Part of Multiculturalism?" Paper presented at the annual meeting of the Conference on College Composition and Communication. 18 March 1994: 2-12. ED 384064.

Troyka, Lynn Quitman. "Defining Basic Writing in Context." $A$ Sourcebook for Basic Writing Teachers. Ed. Theresa Enos. New York: Random House, 1987. 2-15.

White, Edward M. Teaching and Assessing Writing: Recent Advances in Understanding, Evaluating, and Improving Student Performance. San Francisco: Jossey-Bass Publishers, 1988.

Witty, Paul A. and Roberta La Brant Green. "Composition Errors of College Students." English Journal 19 (1930): 388-93.

Yorio, Carlos. "The Other Side of the Looking Glass." Journal of Basic Writing 8.1 (1989): 32-45. 


\section{Appendix A: Survey}

SURVEY: To find out more about the needs of particular groups of writers.

DEMOGRAPHIC INFORMATION (Circle appropriate information) Sex: M F

Ethnic/Cultural: African-Amer Asian-Amer NativeAmer White Other

Marital Status: Single (S) Living Together (LT) Married (M) Divorced (D)

\section{Your Age:}

Children (if applicable, please list ages of all children--include date of any expected children if you are currently pregnant, your approximate age when you had her or him, and your marital status at the time--use above classifications-S, LT, M, D) 1.

$\begin{array}{lll}\begin{array}{l}\text { Child's current } \\ \text { age or due date }\end{array} & \begin{array}{l}\text { Your age at } \\ \text { his/her birth }\end{array} & \begin{array}{l}\text { Marital Status } \\ \text { at the time }\end{array}\end{array}$

2.

3.

4.

Check all of the following resources you have used to support yourself (and your children before you entered college): working full-time working part-time income from a spouse or co-habitor financial (or housing/food) support from family or friends child support payments AFDC medical assistance other (please name)

Check all of the following resources you are using to support yourself (and your children) during college (now) -include college expenses as part of that support: working full-time working part-time income from a spouse or co-habitor financial (or housing/food) support from family or friends child support payments AFDC medical assistance 
grants or scholarships (for college)

financial aid (for college)

other (please name:

\section{Education:}

Did you finish high school? yes or no

Complete your G.E.D.? yes or no

If you did not finish high school, what is the highest grade you completed?

Circle the highest level of education completed by your parents.

Mother:7 $8961011 \quad 12$ A.A./A.S. B.A./B.S. M.A./M.S. Ph.D.

Father: 7889101112 A.A./A.S. B.A./B.S. M.A./M.S. Ph.D.

\section{PRIORITIES}

1. What's most important to you? In each blank, write in a number between 1 and 5 which shows its importance to you. (1=most important; $5=$ =least important; NA= does not apply) spouse/significant other and/or children parents friends work school church home (upkeep, cleaning, etc.) hobbies or sports community activities or volunteer work relaxation entertainment (parties, movies, etc.)

2. How do you prioritize the things that are important to you? Using the same list, rank order them from 1 to 11 using each number only once ( $1=$ most important; $11=$ least important; NA=does not apply) spouse/significant other and/or children

parents
friends
work
school
church
home (upkeep, cleaning, etc.)
hobbies or sports
community activities or volunteer work
relaxation
entertainment (parties, movies, etc.)


3. How much time do you spend with the people who are important to you or doing the things that are important to you? In each blank, estimate the number of hours you spend on a typical day. spouse/significant other and/or children parents friends work school church home (upkeep, cleaning, etc.) hobbies or sports community activities or volunteer work relaxation entertainment (parties, movies, etc.)

4. Look back at question \#2 for the top three things you ranked as most important to you. In what ways does writing interfere with these things?

5. Look back at question \#2 for the top three things you ranked as most important to you. In what ways does writing help you succeed in these areas?

6. What are your reasons for being in college? Why is it important to you?

7. How valuable or useful is writing to your success in college? Rank its value or usefulness with a number from 1 to five; $1=$ most important; $5=$ least important. Explain why you gave it this ranking.

8. What kind of job do you hope to get when you graduate from college?

9. How valuable or useful is writing to your future career? Rank its value or usefulness with a number from 1 to $5 ; 1=$ most important; $5=$ least important. Explain why you gave it this ranking. 
Thank you. If you would be willing to discuss these issues more fully in a small group and/or an individual conference with me, please complete your name, address, and phone number below. There would be some compensation (money or assistance with school or resume writing) for your time.

Name:

Address:

Phone \#:

Appendix B: Narrative Writing Prompt for CCC (2-year rural) and

\section{MCTC (2-year urban)}

Write a paragraph on the topic that appears below. Begin with a topic sentence and then develop it based on your experiences and observations. Use examples, reasons, and details to support your main idea. Make the paragraph as clear and error free as you can. Please skip lines to make your handwriting more legible.

My Worst School Experience 


\section{Appendix C: Argumentative Prompt for PCTS (4-year urban) Students}

\section{Diagnostic Essay}

\section{Directions}

This essay will be used to confirm that you have been placed in the appropriate writing course. Based on the results, your professor may need to notify you of a change in your writing placement; therefore, be certain that you include your telephone number as well as your name and social security number at the top of your essay.

You have the remainder of the class period to plan and write your essay. Before you begin to write, you may wish to take a few minutes to think about your topic and make some notes to yourself on a page of your bluebook. You should also have some time at the end to read and correct what you have written.

To do your best you should:

* express your ideas clearly.

* write in fully developed, well-supported paragraphs.

* avoid serious grammatical errors which could interfere with a reader's understanding of your essay.

* follow the directions carefully and completely.

You have a choice of two topics. Read both carefully before you choose one of them.

\section{Essay Topics}

1. Technology (for example, telecommunications and genetic engineering) is having an increasing influence on our lives. Some people find the increasing influence exciting, but other people find it threatening. Explain why you think technology has had a good influence or a bad influence on our lives. Use specific examples to support your position.

2. It is said that the fact people are living longer is limiting opportunities for young people. Do you agree or disagree with this statement? Explain, using specific examples to support your position. 


\section{Appendix D: Sample Error Tally Form}

Error Type and Number

\begin{tabular}{|l|l|}
\hline spelling & \\
\hline tense & \\
\hline pronoun agreement & \\
\hline vague pronoun reference & \\
\hline & \\
\hline subject/verb agreement & \\
\hline improper verb form & \\
\hline wrong/missing inflected endings & \\
\hline & \\
\hline extra commas & \\
\hline comma splice (in place of .) & \\
\hline no comma in a compound sentence & \\
\hline no comma after introductory element & \\
\hline other missing comma & \\
\hline $\begin{array}{l}\text { improper separation of independent } \\
\text { clauses, run on or fused sentence }\end{array}$ & \\
\hline & \\
\hline fragments & \\
\hline & \\
\hline articles wrong or missing & \\
\hline prepositions wrong or missing & \\
\hline & \\
\hline Singular/plural agreement problem & \\
\hline apostrophe misused & \\
\hline subject/object mix-up & \\
\hline wrongword & \\
\hline \# paragraphs & \\
\hline intro sentence or paragraph & \\
\hline conc sentence or paragraph & \\
\hline & \\
\hline \# examples & \\
\hline total \# words & \\
\hline & \\
\hline transition into example & \\
\hline is example discussed in terms of topic? & \\
\hline
\end{tabular}




\section{Patricia J. McAlexander}

\section{CHECKING THE GRAMMAR \\ CHECKER: INTEGRATING \\ GRAMMAR INSTRUCTION WITH WRITING}

ABSTRACT: In his Grammar and the Teaching of Writing, Rei Noguchi recommends integrating grammar instruction with writing instruction and teaching only the most vital terms and the most frequently made errors. I found that I could follow this advice in my academic assistance composition classes by giving a short course in grammar followed by a grammar checker project. The project provided a review of the grammar lessons, applied many grammar rules specifically to the students' writing, and taught students the effective use of the grammar checker.

Today we find in many college composition classrooms a changing attitude toward teaching grammar. Research during the 1960s, 70s, and 80 s had suggested that grammar instruction, traditionally a major part of composition classes, had a negligible effect on student writing (Hillocks). At the same time, a large number of English teachers began to regard grammar and mechanical errors as superficial and unimportant: content (particularly self-expressive aspects) and organization were the major elements of writing. Thus, during these years a "new paradigm" of teaching developed, one which often neglected the correctness of a final product to focus almost exclusively on the writing process (Hairston).

Rei Noguchi, however, finds problems with this approach. In his 1991 Grammar and the Teaching of Writing, Noguchi argues that style is "just as global ... as organization and content" (13) and that teaching grammar and mechanics can help students improve their style. Further, correctness is important, Noguchi points out, since "many readers, particularly in business and other professional settings, perceive . . [ [errors] as major improprieties" (14). A reason for the "negligible" effect of much grammar instruction, Noguchi speculates, is that "students, though possessing sufficient knowledge of formal grammar, fail

Patricia J. McAlexander is an Associate Professor in the English component of the Division of Academic Assistance at the University of Georgia, where she teaches courses in composition, grammar, and report writing. Her articles have appeared in such publications as The Journal of Basic Writing, Research and Teaching in Developmental Education, and The Rhetoric Review. 
to apply that knowledge to their writing" (7). His conclusion advises moderation between extremes: composition faculty should teach grammar-but not at length and not for its own sake. Rather, they should integrate grammar instruction with writing instruction and teach only the most vital terms and the most frequently made errors (17-18).

\section{Grammar Checkers: A Tool for Applying Noguchi's Advice}

I consider Noguchi's advice sound, and today modern technology has provided a widely available tool that can be used to reinforce that link between grammar and writing: the grammar checker. Grammar checkers, now a part of most word processing programs, flag what they perceive as stylistic, grammatical, or mechanical problems in a document by highlighting or underlining them, and upon request comment on, explain, and sometimes suggest corrections for each problem. As a teacher of what is sometimes referred to as "remedial" English at the University of Georgia, I discovered that many of my students, no doubt concerned about their writing ability, were regularly using grammar checkers. A survey of my three composition classes at the beginning of the 1999 fall semester revealed that 40 of the 51 students, nearly $80 \%$, used the grammar checker when writing-16 always, 24 sometimes, only 11 never. Is using a grammar checker a constructive and appropriate response to eliminating error? Not according to many publications on the subject. Several studies argue that, because grammar checkers have a low rate of identifying errors and because they erroneously flag and "correct" a number of already correct constructions, using them is, in fact, detrimental, especially for inexperienced or weak writers. These studies contend that the devices frustrate students, make them passive, isolate them from real human experience, distract them from the content of their papers, and teach them little (Gerrard; Pennington; Fischer and Grusin). Apparently, the authors of these studies would advise students - and certainly basic writers - never to use the grammar checker.

Much depends, of course, on the definition of "basic writers." Very inexperienced writers, such as those described throughout Mina Shaughnessy's Errors and Expectations, indeed may not be ready to use grammar checkers effectively. However, an increasing number of writers placed in compensatory composition classes today can be described as "intermediate," and this was true of my students. They were regularly admitted into the University of Georgia, many of them with SAT scores of about 1000 . Student placement in academic assistance writing (non-credit pre-freshman composition) was based first, on their performance on an objective test covering grammar and style and second-for those who scored below a certain level-on a sixty-minute essay. Approximately $15 \%$ of incoming freshmen score low on the 
objective test, and $25 \%$ of this group place into academic assistance English because of their scores on the essay.

These students clearly did need to improve their writing before entering "regular" composition, but as their SAT scores and admission to the University show, they had already achieved a certain level of competence. Not only were many already using grammar checkers, but, like most young people, they seemed motivated by technology. Further, I realized that grammar checkers, which I myself had once scorned, were improving - finally becoming, in the words of one expert, "worth using" (Lowe, 36). Thus I decided that, rather than simply advising students to ignore the grammar checker, I would give them instruction in using the tool efficiently. My experience doing so suggests that such instruction alleviates or eliminates negative effects. Further, using the grammar checker in the context of the composition classroom increases the students' knowledge of grammar. In this article, I describe a grammar checker project that I have begun assigning in my academic assistance composition courses.

\section{Background for Instructors}

To teach students about using the grammar checker, instructors must themselves understand the nature of the device and its resulting strengths and weaknesses. A number of sources provide material on this subject: a few of the more recent include Johnson (1992), Major (1994), Beals (1998), Hult and Huckin (1999), and the anonymous "Why Can't My Grammar Checker Automatically Correct My Mistakes?" (1999). Such sources plus my own experience yielded a number of insights. First, grammar checkers are fundamentally pattern matchers; hence they are most reliably helpful on formulaic problems, such as subject-verb agreement, active versus passive voice, excessively long sentences, fragments, comma splices, apostrophes. Sometimes they can also recognize such errors as pronoun agreement, semi-colon use, and parallelism. Second, checkers cannot catch errors that relate to content or meaning, because, of course, they cannot read for meaning. Thus they can do nothing with pronoun reference or modifier errors, and little with commas other than with formulaic "which-that" clauses and omitted commas after introductory transitional words and phrases.

According to some studies, checkers can flag correctly only about one third of a paper's problems - but that is not a bad percentage, given the complexity of language. Moreover, checkers usually offer some setting options that may actually increase this percentage. For example, Microsoft Word can be set to catch the omission of the comma before the "and" in lists and the placement of commas or periods outside of quotation marks. In addition, Word can be set to a particular level of 
language-such as standard or formal. The formal setting will flag "errors" traditionally associated with academic writing, such as contractions, while the standard setting does not. Thus I advise my students to use the formal setting when writing college papers.

Once the grammar checker flags an error, its challenge is to suggest a specific and accurate correction. When the error is very formulaic, it can do so. For example, when it finds an apostrophe error as in the phrase "families upbringing," it can suggest, "Change to family's or families'." Often, however, checkers can give only a generic comment on an error, such as "sentence structure" or "passive voice." The wording of these comments varies among the different grammar checking programs. For the same error, for instance, some checkers will say "fragment," others "no main clause." Some say "No suggestions," others, "Consider revising." At times checkers misread patterns and as a result, flag and/or correct erroneously. For example, when a semi-colon was misused in "The next sentence; however, is harder," the Word 97 checker read the first three words as a complete sentence with a subject-verb agreement error and suggested that the writer say, "next sentences or nexts sentence." Grammar checkers may be improving (as shown by the fact that Word 2000 did not make this error), but misreading will never be totally eradicated.

One can see that students must know some basics of grammar and mechanics in order to use a grammar checker effectively. They need, for instance, to know which apostrophe suggestion to select and what "passive voice," "fragment," or "main clause" means. Second, they need to understand the overall nature of the grammar checkerthe way its "mind" works - in order to use the tool effectively. Finally, they need enough self-confidence to reject incorrect flagging and advice as well as suggestions that do not reflect their own style. The grammar checker project deals with all three needs.

\section{Grammar Checker Project: Part I}

First, throughout the semester, I gave intermittent instruction in basic grammar terms and errors, with short quizzes on what I considered the most frequent and important errors. My choices were based in part on the standards of the university's regular freshman English course, which gives an "editing failure" grade of 20 to any paper that contains, in any combination, four of the following: fragment, fused sentence, comma splice, agreement (pronoun and subject-verb) error, and apostrophe error. I also taught punctuation (to help the students avoid those major sentence errors), pronoun reference and modifier errors (to improve clarity of writing), and parallelism (to improve style).

Then, toward the end of the semester, I assigned the grammar 
checker project, designed to show students the nature of the checker and thereby to raise their efficiency and confidence in using it. The project had two parts. For Part I, I gave each student four to seven sentences that illustrated a specific type of error taught earlier in the semester. (Sometimes the sentences were from the actual quizzes the students had taken.) I also gave the students an answer key showing how to correct each sentence. The students were to "quiz" the grammar checker by typing the sentences on a word processor and seeing what its checker flagged and corrected. Then they were to report to the class on the grammar checker's "scores" in catching the error and giving advice. Most of the students used Microsoft Word 97, which was on my own office computer and in the campus computer labs. (See Appendix I for the assignment sheet and a sample of assigned sentences with Word 97's responses.)

Although Part I was designed to be not scientific research but a learning experience for the students, the "quiz" results did indicate fairly accurately the nature of the grammar checker: they showed that the checkers are strong in identifying many formulaic errors but cannot deal with errors involving meaning and content. Word 97's checker identified $60 \%$ to $100 \%$ of errors with fragments, comma splices, commas in lists (when set to do so), subject-verb agreement, passive voice, and apostrophes. It identified fewer errors $-40 \%$ to $60 \%$-in parallelism, colon use, pronoun agreement, and commas with interrupters (it can recognize the formulaic which-that errors). However, it caught only $25 \%$ of pronoun case errors and none of the errors involving modifiers, pronoun reference, the dash, and fused sentences. (See Appendix II.) When students gave their reports on the results of their grammar checker tests, we projected the "tested" sentences and the checker's responses on a large computer monitor for all to see, and discussed why the computer performed as it did. Through these discussions, students not only reviewed basic grammar errors, but also developed a greater awareness of what kinds of errors the checker could and could not identify and correct.

\section{Grammar Checker Project: Part II}

For Part II of the assignment, students analyzed the advice the grammar checker did give: as they worked on a word-processed paper outside of class, each student was asked to write out three examples of the checker's advice and describe his or her reaction to/use of the advice. Finally, they were to write a brief paragraph on the helpfulness of the grammar checker and how the tool might best be used. (See Appendix III.) When I had read their responses, I summarized them for my classes. 
Most of the checker's responses as described by the students fell into three main categories: 1 ) incorrectly flagged errors and (of course) incorrect advice; 2) correctly flagged errors but "vague" advice ; and 3) correctly flagged errors and specific, correct advice.

Incorrectly flagged errors and incorrect advice. Many of the incorrectly flagged errors were obvious to the students. For example, in a sentence referring to a child's poverty, the student wrote, "It is a part of who he is." The checker said to change "it" to "he." The student of course knew that this response was not correct. In another situation, the student wrote, "People like Gregory are often misunderstood." The checker suggested changing "are" to "is." Again, the student easily rejected the advice. And when the checker wrongly advised putting a semicolon in place of a comma (as it did in the sentence "To grammar check an entire document, click on the $\mathrm{ABC}$ icon,") students generally remembered their lessons on semicolons and knew the checker was wrong. In these situations, most students simply moved right on: "All you have to do is click on 'ignore' and you're on your way." At other times they recognized that they had done something to make the computer misread and worked to fix the underlying problem. For example, a student wrote, "Despite all that we did to impress those who sang the National Anthem with us every weekday morning we had no effect." The computer flagged "that" and suggested putting a comma after the word. The student knew this advice was wrong, but then realized that the place she needed a comma was after "morning." "I felt the computer had helped me discover that there was a problem," she wrote. "It just did not know how to correct it."

Correctly flagged errors but "vague" advice. In category 2 , the checker correctly flagged errors but its advice was not specific, often because all it did was describe the error in general technical terms. For the sentence, "Still he is not accepted by his society," for instance, all that the checker said was "passive voice." Similarly, the checker might simply tell students that they have a "split infinitive" or a problem with "sentence structure." To correct such problems, students need to know the meaning of the grammar checker's term; then they must determine whether they want to change their sentence and, if so, how to change it. In such cases, Microsoft Word's Help option - the "?" in the bottom left-hand corner of the grammar checker box - can be useful. When writers click on the "?," they get a brief rule and/or definition of the grammar term used in the advice, often with examples. Perhaps to enliven the images on the screen, this information is presented by an animated cartoon figure-a wriggling paper clip with bulging eyes. (For an illustration of the information and imagery offered by the "?," see Appendix IV.) Of course, this Help function does not solve all problems. Students must understand the additional information (which sometimes includes further grammatical terms), and they still must 
determine whether the advice is relevant and apply it to their own sentence.

While my students sometimes complained when the checker correctly flagged errors without giving specific advice, it is interesting that teachers often use a similar method of marking errors in papers to be revised. Rather than "correct" each error so that the student passively copies the correction, the teacher merely labels the type of error and sometimes gives a grammar text reference. Students must correct the error on their own, looking up the rule if necessary. This marking technique can initially frustrate students, but if they are able to correct their errors independently, learning is more likely to occur. Likewise, although my students were often at first frustrated when the computer simply labeled an error with a grammatical term, they soon realized that it was not difficult to edit the flagged text. Some, before editing, remembered the term; some referred to the Help option and/or asked me what the term meant; some simply changed the flagged sentence so that the computer would accept it and recognized that the wording had in fact improved. A student who had written "There is no excuse for parents to not be involved in their children's lives" did not know what a "split infinitive" was, but changed the verb to "not to be involved." The computer accepted this wording, and the student acknowledged that the sentence did in fact sound better. And later when he asked me, "What's a split infinitive?," he was obviously interested in my answer. (I was glad for his interest, but did remind him of the Help option.)

Correctly flagged errors and specific, correct advice. Students prefer, of course, category 3: correctly flagged errors and specific, accurate advice. Even in this category, however, the students cannot accept all advice: they must decide whether the computer is in fact right, and, often, choose between suggestions the computer gives. A surprising amount of the computer advice fell into category 3 , and most of my students recognized from our grammar lessons when the advice was correct and which suggestion to choose. When a student omitted an apostrophe, for example, and was given a choice of two ways to fix the error ("parents'" or "parent's"), he knew which to choose because he remembered the "rule." Similarly, when a student wrote, "Gregory's attempt to look clean and prosperous were not convincing," the checker told him to say either "attempt was" or "attempts were." The student immediately knew he wanted "attempt was," commenting, "Good advice." At other times, especially with stylistic advice, students tended to rely on the "sound" of the sentence, usually correctly. When the checker told a student to leave out the final "with" in the sentence "They want to play with children with whom they feel most comfortable with," she simply did so, recognizing that "it sounds less repetitious." 
Finally, when students needed an explanation of the checker's advice and clicked on the "?," they often learned new lessons. When the checker said to add hyphens in the phrase "seven year old child" ("Generally hyphenate a number and its unit of measurement if they modify another noun," explains the Help option), the student followed this advice, commenting, "I didn't know that much about hyphens." Her past tense suggests that she now knew more. Reinforcement of previously taught rules and learning of unfamiliar ones resulted from advice in this third category, as did student awareness of wordy sentences and style in general. In fact, after the checker had repeatedly given them the same rules and stylistic advice, students often did not even request the computer's comments; they saw the underlining of their text and recognized the problem themselves.

\section{Effects of the Grammar Checker Project}

Overall, the students' efficiency and confidence grew as they became more familiar with checker behavior. Their Part II paragraphs on the use of the grammar checker were mostly positive. One student wrote, "I think the grammar checker is an awesome tool. Often I find myself overlooking careless errors. The grammar checker reminds me of those errors." Another student stated, "I have really enjoyed learning through the mistakes that Microsoft Word catches. Lately I have become more aware of the common grammatical errors I tend to make and have really cut down on these particular errors." Most students, however, also expressed awareness that the checkers were not perfect and that, as with any machine, they, the users, ultimately took responsibility: "One needs to use his/her own knowledge"; "One should not do everything the grammar checker suggests nor should one ignore it"; "Creativity and the laws of grammar [ultimately] rest on our shoulders."

Overall, I felt that my students had proved the articles on grammar checkers overly pessimistic in claiming that the devices make students passive, isolate them from real human experience, frustrate them, distract them from the content of their papers, and teach them little. As the student comments show, these writers were not passive, but active, in applying the checker's advice. They certainly did not seem to feel isolated: when necessary, they turned to humans (like me) with questions. Further, as these students became more familiar with the grammar checker, its abilities, and its language, they experienced fewer episodes of frustration. I saw no deterioration of content; the one definite change in the essays was that they had fewer errors. Most important, learning was taking place: as the checker applied grammatical terms and rules directly to their writing, students recognized rules they 
had not recalled while composing, and were introduced as well to new rules and terms relevant to their work.

In summary, by the end of the semester, I realized that the grammar checker project had increased the students' understanding not only of the grammar checker but of grammar in general. I realized also that the project embodied the instructional technique recommended by Noguchi, for using the checker after a brief course of grammar instruction linked many aspects of that instruction directly to the writing process.

\section{Works Cited}

Beals, Timothy J. “Between Teachers and Computers: Does Text-Checking Software Really Improve Student Writing?" English Journal 87.1 (1998): 67-72.

Fischer, Rick and Elinor Kelley Grusin. "Grammar Checkers: Programs That May Not Enhance Learning." Journalism Educator 47.4 (1993): 20-27.

Gerrard, Lisa. "Computers and Basic Writers: A Critical View." Critical Perspectives on Computers and Composition Instruction. Ed. Gail E. Hawisher and Cynthia L. Selfe. New York: Teachers College, Columbia University, 1989.

Hairston, Maxine. "The Winds of Change: Thomas Kuhn and the Revolution in the Teaching of Writing." College Composition and Communication 33 (1982) : 76-88.

Hillocks, George, Jr. Research on Written Composition: New Directions for Teaching. Urbana, IL: Eric Clearinghouse on Reading and Communication Skills, 1986.

Hult, Christine A., and Thomas N. Huckin. The New Century Handbook. Boston: Allyn and Bacon, 1999.

Johnson, Eric. "The Ideal Grammar and Style Checker." TEXT Technology 2.4 (1992): 3-4.

Lowe, Doug. More Word 97 for Windows for Dummies. Foster City, CA: IDG Books, 1997.

Major, Michael J. "Spelling, Grammar, and Style Go Electronic." Managing Office Technology 39.4 (1994): 18-21.

Noguchi, Rei R. Grammar and the Teaching of Writing: Limits and Possibilities. Urbana, IL: National Council of Teachers of English, 1991.

Pennington, Martha C. "Computer-Assisted Writing on a Principled Basis: The Case Against Computer-Assisted Text Analysis for NonProficient Writers." Language and Education 7.1 (1993): 43-59.

Shaughnessy, Mina P. Errors and Expectations: A Guide for the Teacher of Basic Writing. New York: Oxford UP, 1977.

“Why Can't My Grammar Checker Automatically Correct My Mis- 
takes?" English Plus+ News (1999). April 28, 1999 http:// englishplus.com/news/news0299.htm.

\section{APPENDIX I}

\section{GRAMMAR CHECKER ASSIGNMENT}

Directions: These directions are for MICROSOFT WORD, so if possible, use WORD for this assignment. Microsoft Word 97 is available in most computer labs, including the Learning Center in 132 Milledge Hall. Program your personal computer or the one you are using for this assignment (you may need to re-program every time you use a lab computer) as follows:

1) Click on "Tools" at the top of the screen.

2) Click on "Spelling and Grammar."

3) Click on "Options" at the bottom of the menu.

4) Click on "Settings."

5) Click on the down arrow to the right of the top bar, labeled "Writing Style" (unless the word "Formal" already appears in the box). You will see a list of options. Select FORMAL (closest to "academic").

4) On the same menu box at the bottom, use the down arrow to select "always" for "Comma before last item" and "inside" for "Punctuation with quotations."

5) Click on "OK" and then on "close."

\section{PART I}

WRITTEN DUE: Monday, November 15 (MWF classes) or Tuesday, November 16 (T-Th class). ORAL REPORTS will be given during the following class. We will meet in the LEARNING CENTER to use a computer on the "big screen."

What to do: Type the sentences assigned to you on the word pro- 
cessor. In each sentence, there should be ONE error of the type labeled. After typing each sentence, see what the checker underlines in green. UNDERLINE those words on the sentences on your assignment sheet. Then click on the $A B C$ icon (second tool bar from top), see what the grammar checker says, and COPY what the checker says (see lower box on the screen). When you are finished with all your sentences, tally the number and percent of errors correctly flagged (underlined) and the number the checker actually corrected, and fill in the appropriate blanks on the question sheet. If you want to keep the checker's answers to check again later, select "cancel" when you are finished.

\section{SAMPLE PART I}

Active-Passive (though this is not really an "error")

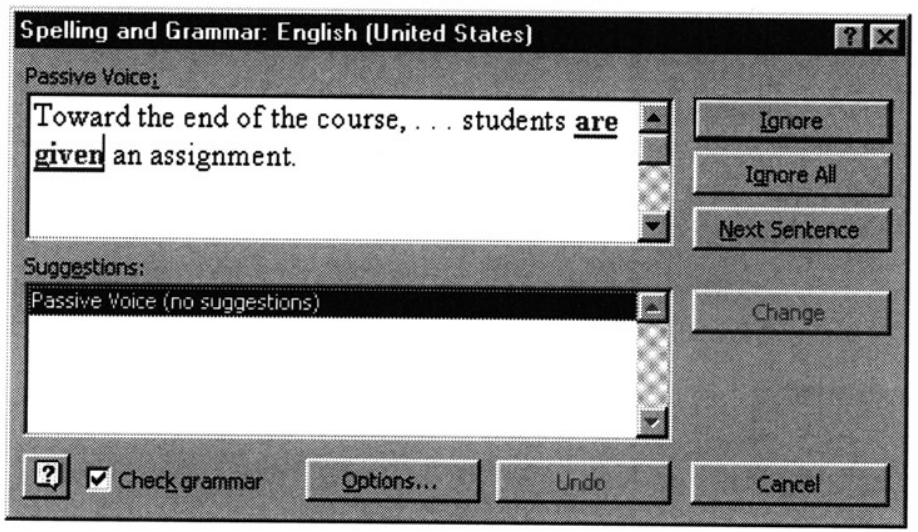

UNDERLINE WHAT THE CHECKER UNDERLINES (if anything) and UNDER THE SENTENCE, COPY in the checker's comment (if any).

Toward the end of the course, ... students are given an assignment.

Passive Voice (no suggestions)

CHECKER'S "SCORE":

How many actual errors are marked by green line? 1 of 1 (percent? 100\% (You may have a "wrong" green line.)

How many of the marked errors are accurately corrected? $\underline{0}$ _ (Makes a specific comment but does not suggest a specific change)

Note: If you do not understand "passive voice" (or any term in the grammar checker's comment), click on the "?" box in the lower left hand corner. Microsoft Word will give a rule and examples that may help you. 


\section{SAMPLE SENTENCES ASSIGNED TO STUDENTS AND WORD 97'S GRAMMAR CHECKER RESPONSES}

(Each section marked by - was given to a different student.)

FRAGMENTS (See Quiz \#2)

UNDERLINE WHAT CHECKER UNDERLINES (if anything) and UNDER THE SENTENCE, COPY in the checker's comment (if any).

1) Although Mary is good in English;she is not good in math.

2) The reason that I was late to class. fragment_ (no suggestions)

3) Getting up early in the morning to swim twenty laps. fragment (no suggestions)

4) When the factory whistle blows at the end of the day.

5) Although Mary is good in English. fragment (no suggestions)

6) My dog has bad habits such as: chewing the furniture. semicolon use (no suggestions)

7) The next sentence; however, is harder than this one. next sentences or nexts sentence

\section{CHECKER'S "SCORE":}

How many actual errors are marked by green line? $\quad 5 \quad$ of $\quad 7$ (percent? 71\% (You may have a "wrong" green line.)

How many of the labels give an accurate correction? $\quad 1$

COMMA SPLICES (See Quiz \#2)

UNDERLINE WHAT CHECKER UNDERLINES (if anything) and UNDER THE SENTENCE, COPY in the checker's comment (if any).

1) Mary is good in English however, she is not good in math. 
2) Some people would agree, others would disagree. comma use (no suggestions)

3) Mary is not always happy, sometimes she is sad.

4) Apes are sociable animals $\varsigma_{\llcorner}$thus they love to have human visitors.

\section{CHECKER'S “SCORE":}

How many actual errors are marked by green line? (percent? 75\% ) (You may have a "wrong" green line.)

How many of the labels give an accurate correction? $\quad \underline{\mathbf{2}}$ 


\section{APPENDIX II \\ THE GRAMMAR CHECKER'S SCORES \\ ACAE Project \\ Part I}

FRAGMENTS

$71 \%$

COMMA SPLICES

$75 \%$

FUSED SENTENCES

$0 \%$

COMMAS IN LISTS

$67 \%$

COMMAS IN COMPOUND

SENTENCES

$0 \%$

COMMAS WITH INTERRUPTERS

$40 \%$ (can do which and that clauses)

COMMAS WITH INTRODUCTORY

ELEMENTS

$50 \%$

QUOTATIONS

(can do periods and commas inside quotation marks if set to do so)

COLON

$50 \%$

DASH

$0 \%$

SUBJECT-VERB AGREEMENT

$83 \%$

PRONOUN AGREEMENT

$50 \%$

ACTIVE-PASSIVE VOICE Will mark passive voices every time, but you may want to use the passive!

APOSTROPHES

$60 \%$

PARALLELISM

$25 \%$

MODIFIERS

$0 \%$

PRONOUN REFERENCE

$0 \%$ 


\section{APPENDIX III \\ PART II}

DUE with your final conference after Thanksgiving, though you can hand the written report in with Essay \#6. You can use this form or type out your answers on a new sheet.

FOR THREE SENTENCES FROM ESSAY \#6 OR AN EARLIER ESSAY:

For sentence one:

1) Give the sentence and underline where the checker underlined. (You can simplify the sentence.)

2) Tell what the checker said.

3) Tell your opinion of this advice. You might comment on some or all of these questions: How clear is the checker's advice? Is it or wrong (in your view)? Did you change your sentence because of the advice? How?

For sentence two:

1) Give the sentence and underline where the checker underlined. (You can simplify the sentence.)

2) Tell what the checker said.

3) Tell your opinion of this advice.

Sentence three:

1) Give the sentence and underline where the checker underlined. (You can simplify the sentence.)

2) Tell what the checker said.

3) Tell your opinion of this advice. 


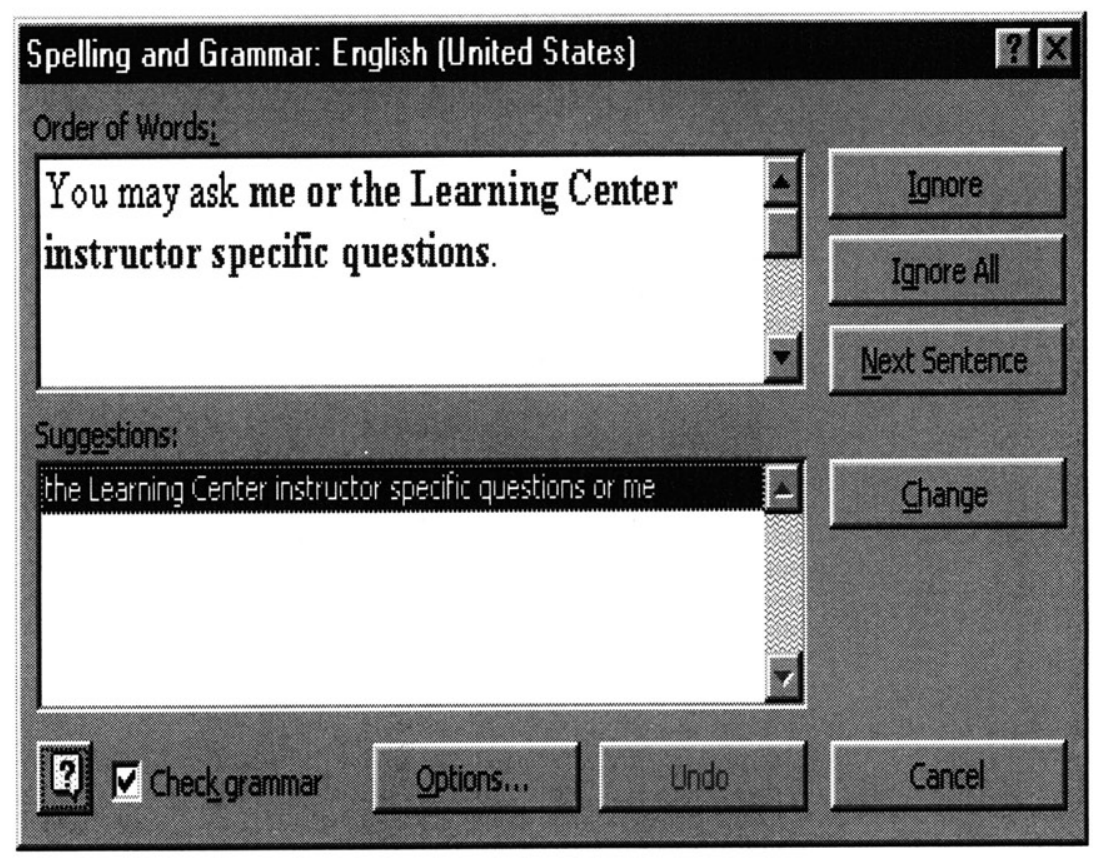

1) Give the sentence and underline where the checker underlined. (You can simplify the sentence.) You may ask me or the Learning Center instructor specific questions.

2) Tell what the checker said. The Learning Center instructor specific questions or me

3) Tell your opinion of this advice. I did not like the checker's suggested wording, but I clicked on the "?" to see if it would give an explanation. The checker then gave this rule: "If you are connecting ' $\mathrm{I}$,' 'we,' 'me,' or 'us' with a noun or another pronoun, place 'I,' 'we,' 'me,' or 'us' last." Thus I changed the sentence to "You may ask the Learning Center instructor or me specific questions." The checker did not underline this revised sentence, and I liked that wording better too.

\section{NOW WRITE A PARAGRAPH:}

Considering Part I (including class reports) and Part II of this assignment - and any other grammar checker experiences you've had, write a paragraph giving advice to someone on how helpful Microsoft's grammar checker is and how it might best be used. If you used this form, attach it. 


\section{APPENDIX IV \\ Sample Response to the "?"' Option}

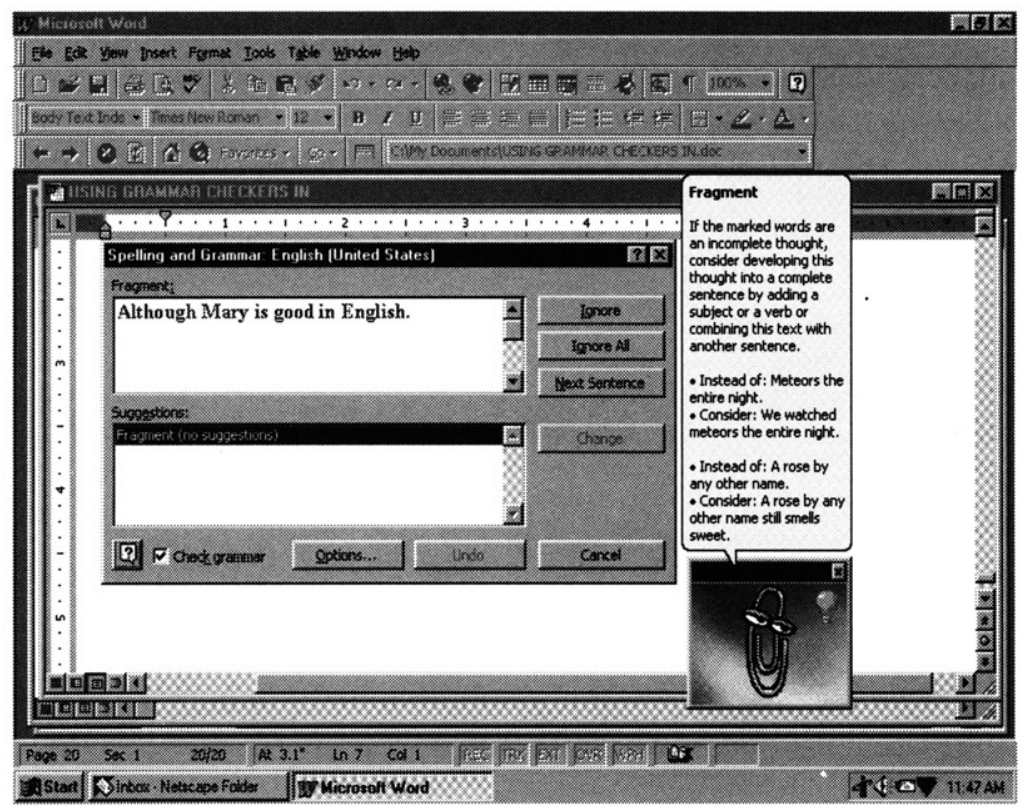




\section{Judith Mara Kish}

\section{BREAKING THE BLOCK: BASIC WRITERS IN THE ELECTRONIC CLASSROOM}

ABSTRACT: This essay fuses theories about Basic Writers and writer's block and addresses, through the use of hypertext, how computers can help Basic Writers who experience this writing difficulty. The essay begins with a discussion of Basic Writers and writer's block, moves to a discussion of a "Stretch" class that I taught in the 1997-8 school year at Arizona State University, and then focuses on problems that the students had in their writing. I discuss the two main branches of their difficulties - problems with genre and problems with the linearity of textswhich may be partially alleviated through the introduction of hypertext theories to the class. Consideration of such highlights specific problems that basic writers may have and adds a new perspective to arguments concerning computer aided instruction and its usefulness in the writing classroom.

Teaching from the Internet, Computer Assisted Instruction, Teaching in the Electronic Classroom - teaching writing in the computer classroom is no longer a path of the future, but is a reality of the present. As such, there are many articles and books espousing the glories and the difficulties of teaching in this electronic environment. Do the computers help students by re-enforcing the notion of recursive writing and revision? Do the computers isolate students? Do they turn the writing classroom into a computer classroom? All of these issues are terribly important and have been discussed, from positive and negative viewpoints, in publications for the last 20-30 years. With all of the words which have been written concerning the electronic writing classroom, however, there has been only cursory interest in and discussion about how the electronic classroom will help or hinder two large segments of the writing population-Basic Writers and students who experience writer's block. In this essay I fuse the two segments and address, through the use of hypertext theories, how computers can help Basic Writers who experience writer's block. Such work, I believe, will highlight this neglected segment of the writing population and add a new perspective to arguments concerning computer aided instruction and its usefulness in the writing classroom.

Judith Mara Kish is a doctoral candidate in Medieval Literature at Arizona State University. Her research in medieval oral texts has led to an interest in "secondary orality" on the Internet, which led her to teach in a computer classroom. She has taught several composition courses, including Basic Writing, in or with the aid of an electronic classroom and is currently working as an English composition substitute at ASU.

() Journal of Basic Writing, Vol. 19, No. 2, 2000 


\section{Defining Basic Writers}

Before addressing how computers can help Basic Writers who experience writer's block, one needs to explore the various definitions of Basic Writing. Since I was new to the teaching of Basic Writing when I began to teach it in 1997-8, I began my reading with Mina Shaughnessy's 1979 book Errors and Expectations. Since Shaughnessy's book is so well known I will not point out the specifics of her arguments, but will note that she focuses the book on the pervasive problems of sentence-level issues, with chapter titles such as "Handwriting and Punctuation," "Syntax," "Common Errors," "Spelling," "Vocabulary," and "Beyond the Sentence" (4). ${ }^{1}$ Although Shaughnessy may be correct in her analysis of the Basic Writers who she encountered, one must be conscious of the fact that not all Basic Writers' problems are at the sentence level. It is for this reason that the instructor must remember the qualification made by Shaughnessy that "I have reached the persuasion that underlies this book-namely, that Basic Writing students write they way they do. . . .because they are beginners and must, like all beginners, learn by making mistakes" (5). Instructors need to recognize that false starts made by Basic Writers may involve commas and spelling, but they also may include coherence and cohesion, organization, and even the pervasive difficulty of writer's block.

It is not solely Basic Writers who experience writer's block; however, one should recognize that there are similarities between the two. Often the same difficulties that authors illustrate as hallmarks of Basic Writing are also those mentioned in association with writer's block. For instance, to define the difficulties experienced by Basic Writers, Shaughnessy notes:

By the time he reaches college, the Basic Writing student both resents and resists his vulnerability as a writer. He is aware that he leaves a trail of errors behind him when he writes. $\mathrm{He}$ can usually think of little else while he is writing. But he doesn't know what to do about it. Writing puts him on a line, and he doesn't want to be there. . . Some writers, inhibited by their fear of error, produce but a few lines an hour or keep trying to begin, crossing out one try after another until the sentence is hopelessly tangled. (7)

This is remarkably similar to Zachary Leader's interpretation of Mike Rose's description of writer's block;

it is the application of rigid, inappropriately invoked or incorrect rules of composition; misleading assumptions; premature 
editing; the absence of 'appropriate planning and discourse strategy'. . .conflicting rules or strategies; and inadequately understood or inappropriate evaluative criteria. $(17)^{2}$

Because of such misplaced rules and criteria, the author becomes paralyzed and is unable to write; he experiences writer's block. Illustrations like those recounted above prompt one to begin to see that writer's block and Basic Writing dovetail into one another. From this conventional view, one might expect to encounter the following scenario:

A Basic Writer comes into a writing classroom with a fear of making grammatical mistakes. This fear of mistakes has been conditioned by the copious amounts of red ink that the writer has seen in the past on essays. Because of this fear, the writer is quite apprehensive in writing sentences, keeps forming them over and over again in his mind, until he thinks that they are "perfect." But the sentences are never perfect, and the writer thinks that he can't write until they are perfect. So, the writer can't write. The writer can't get any words on the page, loses the flow of his thoughts - he experiences writer's block.

In some contexts and for some students, a scenario like the one recounted might be appropriate, however, teachers would do students a service to re-think some of these points which are accepted as "facts." To this end, it may be valuable to examine the issues surrounding a Basic Writing class that I taught in a computer mediated classroom at Arizona State University during the 1997-1998 school year. The observations that I made while teaching the students may serve to problematize the assumptions often made about Basic Writers and writer's block and show how being in a computer classroom and actively drawing on hypertext theories can aid in instruction of these students.

\section{Basic Writing at Arizona State University: the Stretch Program}

At Arizona State University, the "Basic Writing Program" is called Stretch. ${ }^{3}$ This program consists of English 101 content which has been "stretched" over the course of a year, instead of a semester. The first semester of the program is Writing Across the Curriculum (WAC 101) and the second part of the program is English 101 (First-Year Composition) ${ }^{4}$ Stretch is governed by several basic concepts, which are as follows: Basic Writers are capable students but lack experience in writing and therefore need "time to develop effective writing strategies" including "reading strategies. . .invention techniques. . .composing methods... and revision and proofreading strategies." In addition, the goal of all First-Year Composition classes, and more advanced writing 
classes also, is to "help build a writing community" among the members of the class (Glau, webpage). Sometimes the creation of such communities is difficult if the students are only in contact with each other for 15 weeks; however, students in Stretch are in contact with each other for an entire year. Because of this extended period of time, the students have the opportunity to become very familiar with their peers' personalities and styles of writing. As such, it has been my experience that the writing communities which result from Stretch classes tend to be stronger and, perhaps, more fruitful than those in single semester writing courses.

At ASU, students are identified as Basic Writers through scores on the SAT or ACT tests. This is, admittedly, a problematic method of placement. One of my students noted, "How can you base whether or not a person can write on that stupid SAT test? They don't let you write anything. Is writing all about being able to correct a sentence? I don't think so" (Student A 1). ${ }^{5}$ The method of placement for the Stretch Program is primarily based on logistics; it would be very difficult to do a written placement test for the more than 4,000 students who enroll each semester. ${ }^{6}$ Nevertheless, the method of placement re-enforces the conventional notion that the level of skill a student has in writing is directly related to sentence-level concerns such as fixing commas or identifying clauses. Admittedly, grammatical concerns should not be ignored; they are very important and lack of skills in grammar can make a text difficult if not impossible to read. Nevertheless, difficulty in fixing commas does not make one an "unskilled writer." It is truly difficult to determine the definition of Basic Writers, since it is a very subjective area that must be determined by context. I will confine myself to discussing the type of writing and writing difficulties encountered by my students in the 1997-8 Stretch class and I will, therefore, define Basic Writing within this one context.

\section{My Stretch Class}

My Stretch class was computer mediated ${ }^{7}$ and occurred in the same classroom both Fall and Spring semesters. It consisted of 19 students during the WAC 101 portion of the class and 17 during the English 101 portion; two students did not return for the second portion of the class and no new students were added. I entered the WAC 101 class with preconceived notions, largely based upon literature about mechanical errors and Basic Writers, concerning the types of difficulties that the students would encounter in writing. My assumptions, however, proved to be incorrect. In the diagnostic and first graded essays that the students turned in, the anticipated mechanical errors were either simply not there or minimal. For instance, only two stu- 
dents had difficulties with sentence fragments and run-ons. There were a few difficulties with verb tense, spelling, and commas; but only slightly more than in a regular English 101 class. The most marked difference between the Stretch class and a regular English 101 class was the reported infrequency of writing academic prose in high school (some had significant experience in "creative" and "experimental" writing), procrastination, and attention span. ${ }^{8}$ It was not, therefore, a matter of mechanical errors which marked these students as Basic Writers, but a lack of exposure to writing and a deficiency in listening skills.

\section{The Questionnaire: Basic Writers and Writer's block}

Because the hallmarks of Basic Writers and writer's block seemed to be the same, particularly concerning mechanical errors, I anticipated that the two were connected and perhaps fueled each other. This was an incorrect assumption. Perhaps my notions about Basic Writers and writer's block as discussed in earlier sections might have been appropriate in some situations. Nevertheless, being wrong in my assumptions intrigued me and made me begin to re-evaluate my perceptions of Basic Writers from the students' point of view. What were the difficulties that they perceived when they wrote? When did they have difficulty writing? When was writing easy? Did the computers isolate them, or did they create a new social environment which was liberating?

I made several observations concerning these questions during the 1997-8 school year; however, I think that the best comments came from the students themselves. At the end of the Spring semester, I approached them with a questionnaire about their experiences over the course of the year. ${ }^{9}$ Questions ranged from the most helpful and least helpful parts of being in a computer classroom to more specific questions on where they composed most of their papers (in class, the computer center, the dorm) to if they encountered and how they overcame writer's block.

In response to the questions on writer's block, I found that the standardized answer that I had so easily assumed at the beginning of the school year did not apply to this group of students. All of the students acknowledged that they had encountered writer's block in the past, ${ }^{10}$ but when asked why and when they encountered it, their answers were dissimilar from answers I would have expected when I entered the class nine months earlier. The following are some of the responses received concerning at what stage in the writing process the students encountered writer's block: 
Student A-I get writer's block only when I know something must be changed but I can't think how. So I guess in the editing process.

Student B-usually at the beginning

Student $\mathrm{C}$ - the introduction

Student D-The first paragraph. I usually don't know where to begin. As soon as I get the 1st paragraph my thoughts usually flow onto the paper.

Student $\mathrm{E}-\mathrm{I}$ experience [writer's block] right at the beginning. Once I start writing, usually I am O.K. from there. The hard part for me is just starting.

Student $\mathrm{F}$ - In the body paragraphs of the essay (all from page 2 of survey).

The responses indicate two patterns of difficulty concerning blocked writing that this group experienced while composing texts and how these patterns define the group as "Basic Writers." The first writing difficulty, reflected by Student A's response, is "unfamiliarity with genre issues," which I will deal with shortly. The second point is "linearity of texts," reflected in the latter five responses. I will comment on these later in this paper.

\section{Genre Issues}

Concerning "unfamiliarity with genre issues," one may view Student A's response in various ways. Initially, it may be interpreted as consistent with the standard explanation for writer's block, that the writer becomes so encumbered in the process of making a sentence "right" that he can't write anything. This explanation has merit, but is somewhat complicated by the answer which the student gave to the question, "Why do you think that you had writer's block?" to which he answered, "Because I didn't have much knowledge of the style of the papers" (2). What the student may be identifying in this description of his experiences with writer's block are not mechanical concerns but genre concerns. The student encounters difficulty not in how to write a sentence correctly, but how to write a sentence so that it is appropriate for a particular genre; he didn't have the strategies needed when confronted with new writing situations. For instance, one of the essays that the students in my class were assigned was the "Profile" paper, where the student's task was to write a journalistic essay on a person, place, or event which included details from observations, interviews, etc. For this essay one of the genre concerns was tone-one 
needs to write in an objective manner, not including opinionated comments. In addition, the formality of the prose is determined by the audience of the essay; an essay written for The National Enquirer would have a less formal tone than an essay written for Arizona Highways. If the student doesn't understand such genre concerns, then writing prose which is appropriate for genre and audience becomes very difficult, perhaps to the point that the writer experiences writer's block. Adequate introduction to genre, however, can alleviate such writing anxiety and facilitate the writing process. This notion is reinforced by Student A's comment that he no longer encounters writer's block because he has a clear understanding of the genre he is asked to write in and the styles of writing appropriate for that genre (2). ${ }^{11}$

Student A's response encapsulates an explanation of why at least one member of this group of Basic Writers experienced blocked writing-difficulty with genre. Although not identified as a cause of writer's block by the other students, unfamiliarity with genre may have been a potential block in the past for the student writers. Problems with genre certainly is not confined to Basic Writers, but because of their inexperience with writing it likely causes more problems, particularly the inability to begin writing, than it might with more experienced writers. One of the most effective ways that I have found to introduce a new genre to students is to give them examples of the genre and, following this, to ask them to generate possible topic ideas themselves. None of the students in the Stretch class, however, identified invention activities like generating topics for various writing situations as part of their previous writing processes. Without the tools needed to begin to craft essays, it is not surprising that students would have difficulty in writing tasks.

When asked "How does your class help you to work through writer's block?" two students identified invention activities and two students identified research and peer comments, most likely also invention, ${ }^{12}$ as useful block breaking activities. Most composition teachers today do emphasize the role of process in writing tasks and, certainly, the introduction of invention is part of this process. The process of invention can of course take place outside of an electronic classroom, however, I found that the computers allowed the class to share and comment upon each others' invention work in wider manner than would be possible in a non-electronic environment. In addition, the students in my class were able to print out the exact words that their peers used to critique the topics, rather than relying on verbal comments which may or may not be remembered correctly.

For instance, an example of an invention activity that I used in the electronic classroom was asking the students to post five possible topics that they were thinking of using for the assigned paper, such as the Profile, on the class discussion forum. ${ }^{13}$ Students would make com- 
ments on their peer's topics after all of the first postings were made. Using the forum to introduce students to possible topics quickly gave them exposure to various genre issues before choosing a topic and beginning the drafting process. Comments, for instance, ranged from how hard or easy the topics seemed to be-it is more difficult to profile a car race which occurs once than a coffee house which one may visit at any time - to offers of collaboration among students with the same or similar topics. Because of this on-line collaboration, the students were able to comment on many more topics and receive feedback from more peers than would have been possible if the discussion occurred in small groups. Employing the discussion forums in this manner truly allows writing to be a socially constructed activity, where the exchange of ideas occurs among all of the students in the writing community, not just between two or three of its members.

I believe that this variety in exposure to their peers' ideas and feedback helped to decrease incidents of writer's block among the students in the class. Perhaps the best indication that the computers helped students with these genre issues came from the students themselves. To the question "Does having the computers decrease/increase your ability to deal with writer's block?" one of the respondents noted, "Increased, because of the forums" (Student B 3). Another student noted that she enjoyed having discussions on the forums more than having large group discussions (Student D 1). ${ }^{14}$

\section{Linearity in Texts}

Not only did such on-line discussion help the students to become more familiar with genre issues, but it also introduced the students to hypertext. It is through the use of hypertext itself and an understanding of hypertext theories that instructors can begin to help students to use computers to break through writing difficulties such as writer's block. In understanding what is so unique and beneficial about hypertext, one must first recognize the linear organization of "normal" text's construction. The materiality of the written page, in English, is linear. Prose is written from the top of the page to the bottom in lines that are read from left to right. One does not normally begin an essay by flipping to the last page and reading the last sentence first. We should ask ourselves, why not? The reason is because we have been taught to read and also taught to write with a preconceived notion of how an essay should be arranged - linearly. Furthermore, the vocabulary used to discuss the parts of an essay reinforces the linearity of the text. For instance, a student will note that the "introduction" is the beginning of the text; it introduces the subject of the paper. The "body" paragraphs come next; they are the body or middle of an entity, which 
is the text. The "conclusion" comes last, with its obvious root word as a signifier.

When faced with vocabulary, writing, and reading practices which reinforce linearity, how can a teacher help students with writer's block, which is rooted so deeply in linear organization? Certainly, there are ways to approach this problem in a non-computerized classroom, but the utilization of computers and hypertext is a valuable asset in aiding students to relieve writer's block.

George P. Landow is author of several books on hypertext including Hypertext: The Convergence of Contemporary Critical Theory and Technology. In it, Landow quotes Theodor H. Nelson, who coined the term "hypertext" in 1960-hypertext is "nonsequential writing - text that branches and allows choices to the reader, best read at an interactive screen. As popularly conceived, this is a series of text chunks connected by links which offer the reader different pathways" (4). In the Stretch class, we used the most commonly recognizable form of hypertext, the negotiating of links from page to page on the Internet, as a research tool. We also frequently used two more simple forms of hypertext, the class homepage and discussion forums. At the beginning of each class, the students would log onto the course homepage and link to messages, discussion questions for the day, and so forth. In the process of receiving and posting bits of information, the students clicked onto links and moved backward and forward through the webs of information in different ways. As one student would be reading the message board, another student may be checking the syllabus on-line, linking to e-mail, and so forth. Each class period began with hypertext. Because of this, there was a constant reinforcing of hypertext "organizational" structures.

The idea of "organization" in hypertext is an important concept that, not surprisingly, has been influenced by literary, rhetorical, and composition theory. For instance, much hypertext theory is informed by the work of Jacques Derrida, especially the book On Grammatology, and Roland Barthes' $S / Z$. The primary manner in which these works inform hypertext theory concerns the notion of "decentering" the text. This is accomplished through looking at written information in nonlinear manners, by seeing beyond the organizational hierarchy of the "page." ${ }^{15}$ Text ceases to be a static and unified structure; rather, one detects "blocks" of text which may be understood and manipulated in a variety of ways.

Derrida's theories, particularly, have been effective in crossing a variety of disciplines and specializations. In her 1989 volume, $A$ Teacher's Introduction to Deconstruction, Sharon Crowley reviews some of Derrida's work and shows how it may be used practically in the composition classroom. In the process of doing this, one of the points she makes about the power of deconstruction is its ability to make a 
text fluid and adaptable to various writing and reading perspectives. She notes,

any stable formal structure posited for a text is broken by virtue of its essential iterability; one can always link a written syntagma from the interlocking chain in which it is caught or given without making it lose every possibility of functioning, if not every possibility of 'communicating,' precisely (16).

She continues by pointing out that the ability to quote from Derrida in the sentence just recounted, and the audience's comprehension of the sentence, is proof of her assertion that sections of text may be lifted, moved, and manipulated outside of established textual hierarchies. With this in mind, the text becomes fluid; its blocks of information in the form of phrases, sentences, paragraphs, and so forth may be moved about freely and used in a variety of different ways.

The notion of "decentering" established textual hierarchies - such as the simple introduction, body, conclusion of an essay -is reflected in the basic foundations of hypertext. According to Landow, hypertext "provides an infinitely re-centerable system whose provisional point of focus depends upon the reader," and I would also include "the author" as reader $(11)^{16}$. Because of the fluidity of the text, the author or reader is not forced to follow any sort of "standard" organizational pattern. He or she is given the freedom to follow links which allow him to move about the text in a seemingly infinite number of ways. Thus, the "blocks" of text that concern Derrida, and the lifted bits of prose which Crowley's sentence exemplifies, may manifest themselves as tangible, moveable bits of text on the computer screen of student writers.

\section{Linearity of Texts and My Stretch Class}

As noted earlier, at the beginning of each period, the students would go to the class homepage, which often resulted in linking to the class discussion forum. On the forum, students posted comments on assigned readings and completed invention activities, among other tasks. In the process of posting to the forum, the students would also access their peers' comments through links (the student's name) and reply to their peers. Because of the fluidity of the links, the "center" of the text often began with the discussion question posted for the day, but very quickly became displaced. If a student posted a particularly interesting comment on an assigned reading, for instance, other students would begin to comment on it. The "center" would change to that student's comment, until of course a respondent to the peer be- 
came the "center," and so forth. Throughout a discussion forum, the "center" of the text continually shifted from moment to moment, entry to entry.

As with the invention activities on the forum, each student had the opportunity to post his or her ideas concerning a given topic. In addition, they had the ability to almost simultaneously access 17 other perspectives on the forum. The original input that the students had, therefore, often would change over the course of discussion as they read different perspectives posted by other students. What initially seemed to be the "right" or "moral" answer to an ethical question, for instance, began to be complicated by other students who brought different ethical codes and life experiences to the discussion. In this manner, hypertext organization and discussion manifested concretely the social construction of ideas and of texts, both individual and communal. ${ }^{17}$

In addition to the content of the information generated through forums, this process of generating text allows the students to act as both authors and readers of hypertext. ${ }^{18}$ For instance, the organizational hierarchies are not as relevant in this medium as they would be if the students were required to write an in-class essay on paper. In the discussion forum, there is no need for an introduction or a conclusion. One might even posit that there isn't a true "body" of structured information either, as the students are free to write complete questions, sentences, phrases, lists, in capital letters, with(out) punctuation, etc., whatever was necessary to comment on the assigned question or their peers' work. The main concern was simply that their peers could understand their comments, that the communication so integral to Derrida's deconstruction would be effective.

Because of the daily re-enforcing of hypertextual organization, it is easier to characterize the word processing programs that the students used to write their essays as a form of "pseudo-hypertext." In doing this, the organizational hierarchy of essay writing - begin with the introduction and proceed through to the conclusion-begins to break down. On a basic level, Landow points to the connection between hypertext and word processing when he discusses the "ease of cutting, copying, and otherwise manipulating texts [which] permits different forms of scholarly composition" (22). But truly, this is just the beginning of how computers may be used in composition. More important for writers who experience writer's block is the idea that "hypertext makes determining the beginning of a text difficult because it both changes our conception of text and permits readers to "'begin' at many different points" (58). Within true hypertext, such as a web page or the discussion forums mentioned earlier, the beginning and ending of a text is subjective and based upon which links the reader wishes to choose. This textual fluidity may also, with some work, be 
applied to word processing.

Beyond the cutting and pasting options of word processing programs, the computer can also aid writers who experience writer's block through the "changing perceptions" of where the "beginning" of the texts are. These changed perceptions will not happen automatically, though. Teachers must make explicit for the students the options that word processing programs make available and how these options connect to the hypertext organization used on the Web. To exemplify the way in which word processing can change how students think about and approach writing, one needs to recall the student survey respondents, particularly Students B-E. Although one of the students who answered the survey (Student A) had difficulty with genre issues, five of the six students recounted blocks at the beginning stages of writing. They had difficulty in writing in an introduction (four responses) or body paragraph (1 response) format. When the students were asked why they thought that they encountered writer's block at these stages, the answers ranged from to having a hard topic (1), to not knowing why (2), to not knowing how to start (2). Concerning this last point, one student wrote "I didn't know where to begin or how to begin with a good opening paragraph" (Student D 2, italics added).

Student $\mathrm{D}^{\prime}$ s comment is very revealing of two different concerns that students have when writing. One concern is "where to begin" and the second is how to begin with a "good paragraph"; both points, I think, deserve some attention. From the first point, one might surmise that the students had difficulty with beginning the narrative because they were in need of more invention and organizational activities. I believe that this, because of points noted earlier, would not be correct. Although only two of the students ventured reasons for their difficulty with the introduction, four of them did note that they literally had trouble getting those first few sentences. They felt "stuck" at the introduction. One might ask, why?

Unlike the traditional explanation that sentence level mechanics were the culprit of writer's block, these students were blocked by the notion that the introduction needed to be written first. The reason for this may lie in the fact that the introduction is where one traditionally "begins" an essay, whether one is reading or writing it. "Introduction," however, is quite different from noting that one has difficulty in "getting started", "jumping in" or even "composing" a paper. Although we may use these words as synonyms for beginning, there are actually nuances of difference among them. "Beginning" implies that there is an imagined linear structure with a start and a finish; one is attempting to initiate one of the boundaries of this continuum - the introduction -in order to get to the other-the conclusion. Of the three other phrases, "getting started" does, admittedly, have some of the same qualities of linearity invested in its meaning; however, the linearity is 
not as embedded in its meaning as it is in "begin." One may "get started" with a conclusion, a body paragraph, and so forth; it is a much more fluid term. The other two terms do not have linearity as an inherent part of their meaning. "Jumping in" seems to negate any organizational hierarchy, as one may enter the text from any point indiscriminately. "Composing" also can be non-linear in meaning, especially if instructors have emphasized that composing papers is a recursive process, including deleting and adding information in revision, editing, and so forth. For these reasons, it is significant that the student used "beginning" rather than any other term to indicate the step in the writing process where she encountered difficulty.

Also important in Student D's statement is the idea that the introduction had to be "good." People who have had experience with the writing, revising, and editing process, the word "good" may seem a bit comical. It is very rare (if it ever indeed occurs) that a writer composes a polished introduction to a text during the drafting process. Normally, the introduction of texts are written and rewritten as the arguments in the body of an essay evolve and become more solidified. Often the introduction of long works, such as books, are left until last. Indeed, how can one introduce a text that has not been written yet? But students, particularly Basic Writing students, do not necessarily understand this and develop writer's block at the beginning of the writing process because of their idea that the introduction must be written first and if they can not write it, then they can not move on to the body paragraphs. One must remember that "Basic Writing students write they way they do. . .because they are beginners and must, like all beginners, learn by making mistakes" (Shaughnessy 5). They have not yet had enough experience writing to realize that it is OK to throw out an introduction that doesn't work. They don't understand that the draft introduction is very rarely if ever "good."

The benefit of viewing word processing through the lens of hypertext organization is that one does not need to approach the essay to be written in a linear fashion. ${ }^{19}$ If the difficulty of writing occurs in the "beginning" of the paper, then the introduction should be, in essence, ignored. Spending time trying to craft a "good" introduction often results in the student being very reluctant to modify the introduction, even if it doesn't fit the rest of the paper. The student then must be convinced through conferences with the instructor, peer review, and as a last resort grading to understand that the "good" introduction written at the beginning of the writing process does not necessarily reflect the direction the text took at the end of the process. The student would be better served to ignore linear structures and simply "jump into the paper," by beginning to write the body paragraphs first.

The fluidity of hypertext organization, which emphasizes the interchangeability of blocks of writing, can allow students to see how 
their blocks of text may be moved around in the paper. The second sentence of the third paragraph may serve as the topic sentence of a new second paragraph. The last paragraph written may end up being the introduction that so eluded the student when he/she was trying so hard to compose the "beginning" of the paper. What results from this fluidity is, in essence, a "re-visioning" of the text. Through the ease of moveable text, the student should begin to see the various possibilities in his/her ideas, possibilities that might not be explored if they are not easily manipulated on the computer screen.

\section{Some Problems to Consider with the Electronic Classroom}

Although there are many benefits to using computers in the classroom, only some of which are noted in this paper, one must always keep in mind that the use of the electronic composition classroom may not be particularly beneficial to all students, such as first year composition students who may be primarily concerned with the basics of writing, rather than with computers. Also, students who come into a class with little or no experience with computers may feel completely overwhelmed and experience writer's block and other writing difficulties because of computer anxiety. Although the instructor should anticipate such potential problems and strive to make the students feel comfortable with the technology at the beginning of the course, he/ she must remember where the emphasis of the phrase "electronic composition classroom" lies. Such classrooms should be writing courses first; they are not computer classes. The computers are tools to aid students in the writing process; they should not subsume writing as a priority.

For some students, however, difficulties with technology will overshadow the purpose of the course, resulting in the course becoming a frustrating "computer class," not a writing classroom. Basic Writers, particularly, may fit into this category. ${ }^{20}$ In addition, one must remember that Basic Writers often need additional time and more individual attention during the composition of essays. Difficulties with learning computer applications may take valuable time away from the writing process, time which is needed by such novice writers. For such students, computer mediated instruction may not be beneficial and should not be obligatory.

Student A's comments re-enforce this argument. Although he was a gifted writer who excelled in the class and was in no way overwhelmed by the technology, throughout the course he often questioned the necessity for and application of computers in writing classrooms. At the end of the course when questioned if computers helped or hindered his writing process, he noted, it "hasn't done either. My writing 
skills have improved because of the class. . the computer is not a teacher; it can't improve my skills. But it hasn't hindered them either" (Student A). Although I would agree with Student A's assertion that the computer isn't a teacher and that it alone can not improve writing, I believe that the benefits of introducing computers in an electronic classroom are far greater than any difficulties which one might encounter with them. The major advantage of using computers is that their applications can change the way that students think about their texts. They can use word processing programs from the point of view of hypertext theories to "re-vision" texts, thus helping students through writing difficulties like writer's block.

\section{Conclusion}

At the beginning of this essay, I referred to a quote by Shaughnessy, "Basic Writing students write the way they do. . .because they are beginners and must, like all beginners, learn by making mistakes" (5). For the Basic Writers in my class, the inexperience manifested itself in the students' inability to begin writing. Although I do not presume to generalize that all Basic Writers' blocks are caused by genre issues, I suspect that this may be the cause of more blocks than we recognize. Instead of just focusing in on the grammatical issues in a Basic Writer's prose, instructors should begin to look at his/her texts in a more global manner. In doing so, teachers may find that some of the greatest difficulties in writing, from the student's point of view, are getting past the blocks caused by an inability to "begin." Through the help of computer composition, the students may begin to re-think the linearity of texts. They may recognize that "beginning" a text doesn't necessarily mean writing the "introduction"; texts truly begin in invention, which may lead to the composition of body paragraphs, the conclusion, even the last sentence. Writing is a recursive process including multiple revisions; teaching with the computer and emphasizing the non-linear recursive opportunities in word processing may help students begin to see the possibilities of their texts.

\section{Notes}

1. Shaughnessy's book has been invaluable in shedding light on and re-evaluating the difficulties of Basic Writers, whose writing previously may have been labeled "dumb" or "incomprehensible." The book, though it has been problematized recently, is still useful in introducing teachers to the beginning of Basic Writing programs. It has unfortunately, however, also been taken as the last word on Basic Writing by some people, a problem that I encountered when I began to teach Basic Writing courses. 
2. Leader, interestingly, also notes that "if by cognitive blunders are meant errors or deficiencies in knowledge, then these are the blunders of unskilled [basic] writers" (17). Such comments indicate how closely the definitions of Basic Writers and writer's block overlap.

3. For more detailed information about the Stretch Program at ASU see Greg R. Glau's “The 'Stretch Program': Arizona State University's New Model of University-level Basic Writing Instruction," in Writing Program Administration, 1996.

4. All papers I taught originated from assignments in the St. Martin's Guide to Writing, with the exception of the last paper in WAC 101 which was developed by Dr. Greg Glau, Director of the Stretch Program at ASU. In WAC 101 during the year I taught, the papers included "Remembering Events," "Remembering People," "Sub-Cultural Analysis" (profile). In English 101, papers included "Profile," "Explaining Concepts," and a teacher's choice paper. The last paper that I chose in English 101 was a collaborative mini-research paper on a "student choice" social issue.

5. The names of students have been omitted and the surveys have been lettered Student A-F.

6. For Fall 1998 there were 4072 students who enrolled in entry-level composition classes. Of this number, 3165 were placed in English 101, 413 in WAC 101, 289 in English 105 (Honors English), 168 in English 107 (ESL English 101), and 37 in WAC 107 (ESL WAC 101).

7. When I say "computer mediated" I mean that each student had a computer in the class and used it to participate in class group and individual activities, such as those described later in this project.

8. After discussing with colleagues my surprise at the level of writing in my Stretch class, I found that this level was not inconsistent compared to other sections at ASU. What was common among the classes was, surprisingly, that the students seemed to have a shorter attention span and weaker listening skills as compared to personal observations of English 101 students. Although this observation is too vast to examine here, it is a point which might be useful for future studies concerning Basic Writers.

9. Of the 17 students in the English 101 portion of the class, 16 received surveys ( 1 was absent) and 6 were returned. Part of this small number of responses is possibly related to issues of privacy, as the students 
who turned in the survey had full knowledge and gave permission for their responses to be used in research which would be publicly disseminated.

10. Although I did not define what I meant by writer's block on the questionnaire, I had discussed it during the course of the semester, just as I had discussed the meaning of invention, revision, and so forth. By the time that the students completed the survey, they were familiar with these terms and how they applied to their own writing processes.

11. Although the student does note that he no longer encounters blocked writing, one must be a bit suspicious of this comment. All writers at some point in their careers are faced with the "blank page," and most likely this student will be as well. It is significant, however, that he felt comfortable with the genre used in the class after learning invention strategies and planning techniques which helped him in the drafting process.

12. I believe that if the students meant peer review, that they would have identified this. Because they did not address peer review by name, I believe the students meant invention activities.

13. The software used in my Stretch class was called Web Course In A Box, which includes a windows-based "course page" program. From the main menu of the course page, the students click on an icon for "learning links" which takes them to a menu for "forums." They click on the appropriately named forum link, such as "Profiles - Topic Generation," for a given class period. The opening remark is a prompt from me such as "List five of the topics which you generated for homework last night. After posting your topics, comment on as many of your peers' topics as time allows. Be sure to be specific in your comments, taking into consideration the purpose of this essay, the intended audience, and authorial persona." After this prompt, the students click on a link to "reply" to my message, after which a screen with boxes where they are to write their message appears. After typing in the message and clicking the "post message" button, the response appears on the forum page under my original message as a link (indented 5 spaces) which the other students can access and respond to. Students click on one of their classmate's links, get a message screen like the one they used to post their own invention homework, and click on the "post message" button to post their responses to the peer.

14. This is a rather interesting comment as the forums are class discussion. They are, however, conducted in a format different from "traditional" class discussions. 
15. I put "page" in quotes as an indication that some of the blocks of text may present themselves in printed form, but the blocks of text may also be on a "page" which is the computer screen.

16. Three chapters after this statement, Landow does make the connection between the reader of hypertext and the writer - "the figure of the hypertext author approaches, even if it does not entirely merge with, that of the reader" (71). Although it is important that Landow connects the two, I do not believe that he goes far enough in his assertions. In the process of creating the text and reflecting on it in revision, the author becomes a reader. This is especially true if the author has written the text in a truly "non-linear" manner. Reading the text as an audience member may be the first time that the author sees the text in a linear manner.

17. It is true that this sort of "decentering" may also occur in a class or small group discussion among students, however, this sort of discussion is not normally recorded in a manner in which the students can clearly see a progression, or evolution, of ideas. Also, the "anonymity" of the screen sometimes lets "voices" of quieter students be heard more than they might in a class discussion setting. For instance, I found that many of the students in my class who sat in the back of the room and did not participate in large class discussion because of shyness were some of the more "vocal" participants in forums. Thus, I have found that it is the record of the conversations coupled with the greater variety of class voices which makes the hypertext form of "decentering" quite useful in a classroom setting.

18. One may argue that students are authors and readers of print texts as much as they are when composing on the computer. To some extent this is true, however, I believe that the interaction of student/author/reader is amplified through the use of computers because they create, in the words of Walter Ong, a "secondary orality" for the writer which is more closely analogous to a real "audience" (and hence purpose, context, etc.) than that in print texts.

19. It is true that one need not begin with an introduction if one is writing on paper, a point which may be emphasized in the electronic and the non-electronic classroom. The hard copy of a paper, which is most often the copy that is graded for the student, however, will follow a linear format. With the final product in mind, a student may have a difficult time separating a linear draft from a linear final paper. In this way, using computers in class and emphasizing hypertext structures can help students to realize the difference between a draft and a copy of the paper which is "due." 
20. Of the 19 students who began the Stretch class, only about three owned computers and about five had prior experience with computers, particularly word processing. Although the students did learn the applications rather quickly, unfamiliarity with the programs was a difficulty during the first month of class. Some of the students still had difficulties with the Internet even at the end of the course.

\section{Works Cited}

Crowley, Sharon. A Teacher's Introduction to Deconstruction. Urbana: Illinois: National Council of Teachers of English, 1989.

Elbow, Peter. Writing with Power: Techniques for Mastering the Writing Process. New York: Oxford UP, 1981.

Glau, Gregory R. "The 'Stretch Program': Arizona State University's New Model of University-level Basic Writing Instruction." Writing Program Administration. 20.1 (1996), 79-91.

-. "The STRECH Program (WAC 101/ENG 101 \& WAC 107 ENG 107)." http://www.asu.edu/clas/english/composition/ Stretchprogram.html. 25 October 1998.

Haas, Christina. Writing Technology: Studies in the Materiality of Literacy. Mahwah, NJ: Lawrence Erlbaum Associates, 1995.

Landow, Peter. Hypertext: The Convergence of Critical Theory and Technology. Baltimore, Maryland: The Johns Hopkins UP, 1992.

Leader, Zachary. Writer's Block. Baltimore, Maryland: Johns Hopkins UP, 1991.

Ong, Walter J. "Literacy and Orality in Our Times" A Sourcebook for Basic Writing Teachers. Ed. Theresa Enos. New York: Random House, 1987. 45-55.

Shaughnessy, Mina. Errors and Expectations: A Guide for the Teacher of Basic Writing. New York: Oxford UP, 1977. 


\section{News and Announcements}

Call for Papers: The new journal Pedagogy: Critical Approaches in Teaching, Literature, Language, Composition, and Culture seeks submissions. The journal is intended to energize the discourse in English studies, bringing together theoretical approaches and practical discussions of methods and materials used in real classrooms. Submissions should be full-length essays of no more than 35 typed pages. Contact Editors Marcy Taylor or Jennifer Holberg at pedagogy@calvin.edu or Pedagogy Editorial Office, Department of English, Calvin College, Grand Rapids, MI 49546 for more information.

Call for Articles: Feminist Teacher seeks articles on the theory and/ or practice of feminist pedagogy; annotated course descriptions; bibliographical essays, and letters to the collective. For more information or for a copy of the guidelines for authors, contact Theresa D. Kemp, Feminist Teacher Editorial Collective, University of Wisconsin-Eau Claire, Department of English, Eau Claire, WI 54702-4004 or by e-mail at feminist-teacher@uwec.edu.

Call for Articles: College English is soliciting manuscripts for a special topic issue "Lesbians and Gay Studies/Queer Pedagogies," which will be guest-edited by William J. Spurlin. Essays are sought that critically engage lesbian and gay studies with the discipline of English and that explore the pedagogical implications of such a relationship. Deadline for manuscripts is March 15, 2001; contributions should be no more than 20 double-spaced pages or 6,000 to 7,000 words, including notes and works cited list and should follow the most recent MLA style guidelines. Accepted essays will appear in the January 2002 issue. Send manuscripts directly to William J. Spurlin, School of English, Cardiff University, Humanities Building, P.O. Box 94, Cardiff, CF10, 3XB Wales, UK. For more information, contact Professor Spurlin by e-mail at SpurlinWJ@Cardiff.ac.uk.

Call for papers: JAC (A Journal of Advanced Composition Theory) invites submissions of articles on a variety of topics related to writing, rhetoric, multiple literacies, and culture. Use current MLA style and send three copies, stripped of identifying information to Professor Lynn Worsham, Editor, JAC, Department of English, University of South Florida, Tampa, FL 33620-5550 or for additional information contact her at 813-974-9536 or Lworsham@chuma1.cas.usf.edu.

Call for articles: Written Communication seeks submissions on a variety of topics relating to theory and research in writing from a 
variety of disciplinary perspectives including anthropology, English, history, journalism, linguistics, psychology, and rhetoric. For detailed information about submissions, please see any recent issue of Written Communication or visit the web site http://www.wisc.edu/ english/composition/written communication/Wcwebpg.

Read-In Announcement: $12^{\text {th }}$ National African American Read-In Chain on Sunday, February 4, 2001 at the designated hour of 4:00 pm EST, 3:00 CST; 2:00 MST, and 1:00 PST and on Monday, February $5^{\text {th }}$ in the schools. The event is part of Black History Month and the goal is to have at least one million Americans across the country reading works by African American writers on February 4 and $5^{\text {th }}$. For further information, contact Jerrie C. Scott, National Coordinator at the University of Memphis, 322 Administration Building, Memphis, TN 38152.

Conference Announcement: $52^{\text {nd }}$ Annual CCCC Convention, March 14-17, 2001 at The Mark Adam's Hotel in Denver, Colorado. Theme is Composing Community and featured speakers include Victor Vitanza, George Hillocks, Jr, Patricia Bizzell, Peter Elbow, Jacqueline Jones-Royster, and Victor Villanueva among others. For conference information visit the web site at http://www.ncte.org or call toll-free 800-369-6283, ext. 3849.

Conference Announcement: $35^{\text {th }}$ Annual Teachers of English to Speakers of Other Languages, Inc. (TESOL) Conference, February 27-March 3, 2001 at the St. Louis Convention Center, St. Louis, Missouri. Theme is Gateway to the Future of TESOL and includes discussions of teaching on-line, strategies for underprepared ESL students, assessment issues, critical literacies, and teacher research among others. For conference information, visit the web site http:// www.tesol.edu, or contact the organization by phone at 703-836-0774 or by mail at TESOL, 700 South Washington Street, Suite 200, Alexandria, VA 22314.

Conference Announcement: $1^{\text {th }}$ Annual Conference on Computers and Writing, May 17-20, 2001 at Ball State University, Muncie, Indiana. Theme is "2001: A Cyber Odyssey" and will include discussions of such topics as: What technologies have we adopted out of necessity? What are our current choices? Which directions should we follow and which pitfalls should we avoid? For more information, visit the conference web site at http:// www.bsu.edu/cw2001. 
Institute Announcement: $22^{\text {nd }}$ Kellogg Institute for the training and certification of developmental educators, June 23-July 20, 2001 at Appalachian State University, Boone, North Carolina. For applications and additional information, visit the web site http:// www.ncde.appstate.edu, or contact Sandy Drewes, Director of the Kellogg Institute, or Maggie Mock, Administrative Assistant, National Center for Developmental Education, ASU Box 32098, Appalachian State University, Boone, NC 28608-2098 or by phone at 828-262-3057.

Call For Proposals: Writers for the $21^{\text {st }}$ Century, a conference on collaborations across disciplines, campuses, and generations, October 7-9, 2001, Hobart and William Smith Colleges, Geneva, New York. Keynote speakers Dorothy Wickenden, Executive Editor of The New Yorker, and David Gergen, Editor at Large for US News and World Report . A FIPSE-sponsored conference, "Writers for the $21^{\text {st }}$ Century" will be workshop-based, allowing faculty and student authors and coauthors the opportunity to discuss their writing with others and continue to develop their work onsite using campus computer facilities. Include the name, address, phone, fax, email, and institutional affiliation of each author, 250-word description of the article to be workshopped at the conference. Planners are most interested in: effective assignments, writing as public service, the benefits of collaboration, cross-cultural rhetorics, writing and the first-year experience, and the rhetorical needs of science and disciplines. The postmark deadline for proposals is April 2, 2001. Information: Eva Bach, Writing and Rhetoric Program, Hobart and William Smith Colleges, Geneva NY 14456.

Call for Papers: The Twenty-Seventh Wyoming Conference on English: Crisis in the Text? June 20-23, 2001 invites colleagues from across our discipline and beyond to debate whether there is a crisis in the text, what it might be, whether it has always been there, how much we need it. We welcome theoretically conscious papers and presentations from critics, theorists, rhetoricians, creative writers, and scholars from other disciplines on written, spoken, seen, imagined, reconstructed, deconstructed, constructive, disruptive text. Proposals no longer that two double-spaced pages should reach the following address by March 15, 2001. Caroline McCracken-Flesher, Conference Director, Department of English, Box 3353, University of Wyoming, Laramie WY 820713353. Information contact Amy Hollister at the above address, or amyh@uwyo.edu. 


\section{Composition and Bhetoric Studies, Ph. D. Program in English}

\section{The Graduate Benter of \\ The Gity University of New York}

For further information, write to: Composition and Rhetoric Area Group, English Program

Graduate School and University Center The City University of New York 365 Fifth Avenue New York, NY 10016-4309

Or, visit our English Program website: http://web.gsuc.cuny.edu/english/home.html

\section{Tel.: 212/817-8315}




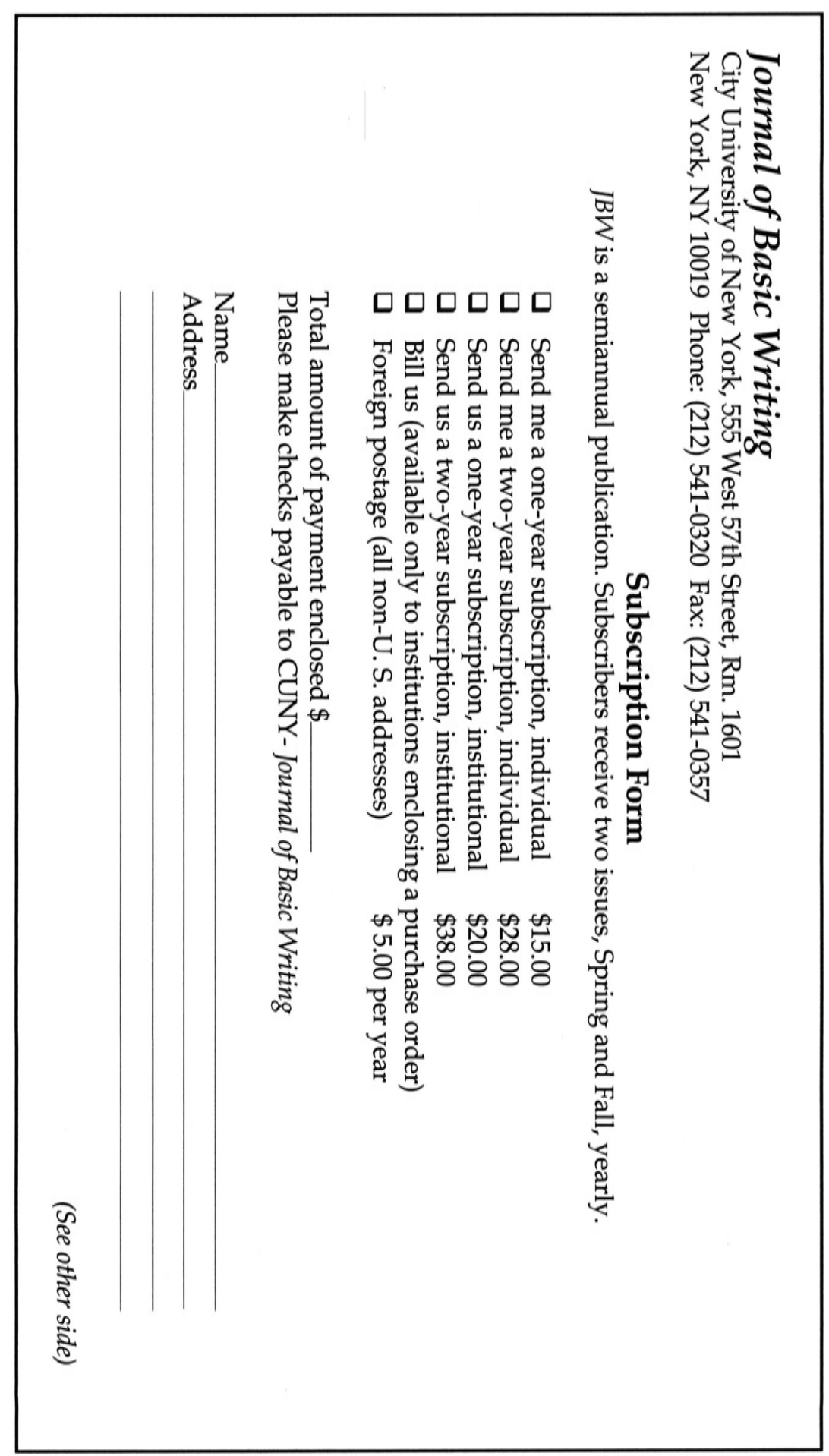




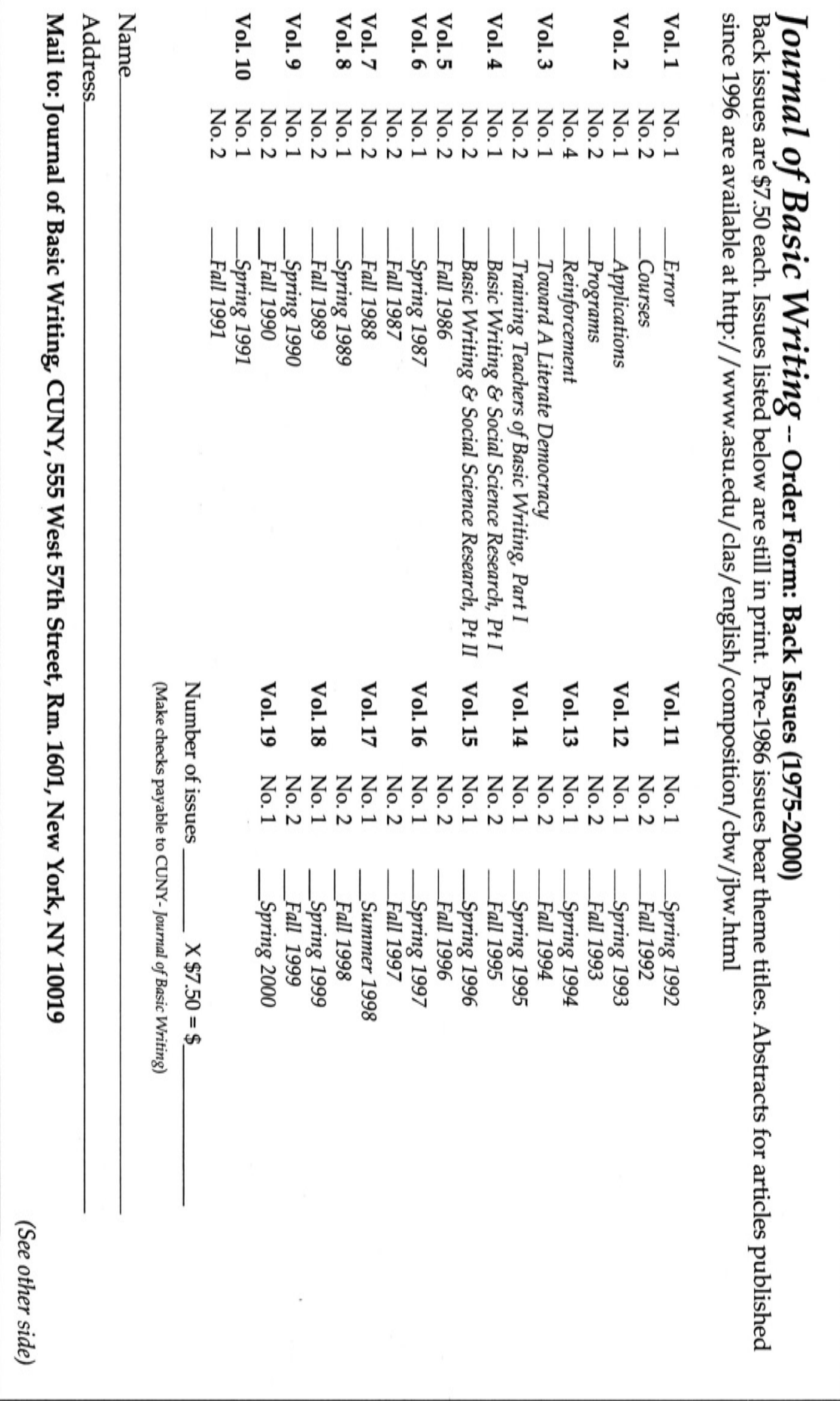





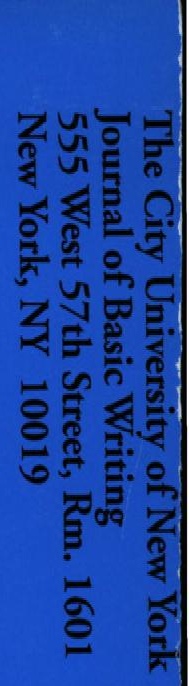

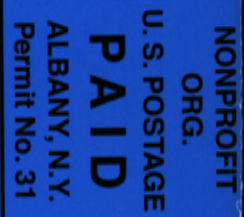

